Portland State University

PDXScholar

1971

\title{
The rhetoric of Sir Thomas More and Dietrich Bonhoeffer in original work and dramatic portrayal
}

Robert C. Harvey

Portland State University

Follow this and additional works at: https://pdxscholar.library.pdx.edu/open_access_etds

Part of the Other Rhetoric and Composition Commons, Social Influence and Political Communication Commons, and the Speech and Rhetorical Studies Commons Let us know how access to this document benefits you.

\section{Recommended Citation}

Harvey, Robert C., "The rhetoric of Sir Thomas More and Dietrich Bonhoeffer in original work and dramatic portrayal" (1971). Dissertations and Theses. Paper 1124.

https://doi.org/10.15760/etd.1124

This Thesis is brought to you for free and open access. It has been accepted for inclusion in Dissertations and Theses by an authorized administrator of PDXScholar. Please contact us if we can make this document more accessible: pdxscholar@pdx.edu. 
AN ABSTRACT OF THE THESIS OF Robert C. Harvey for the Master of Science in Speech presented July 29, 1971.

Title: The Rhetorle of S1r Thomas More and Dietrich Bonhoeffer in OrIginal Work and Dranatic Portrayal.

APPFOVED BY MEMBERS OF THE THESIS COMMITIEE:

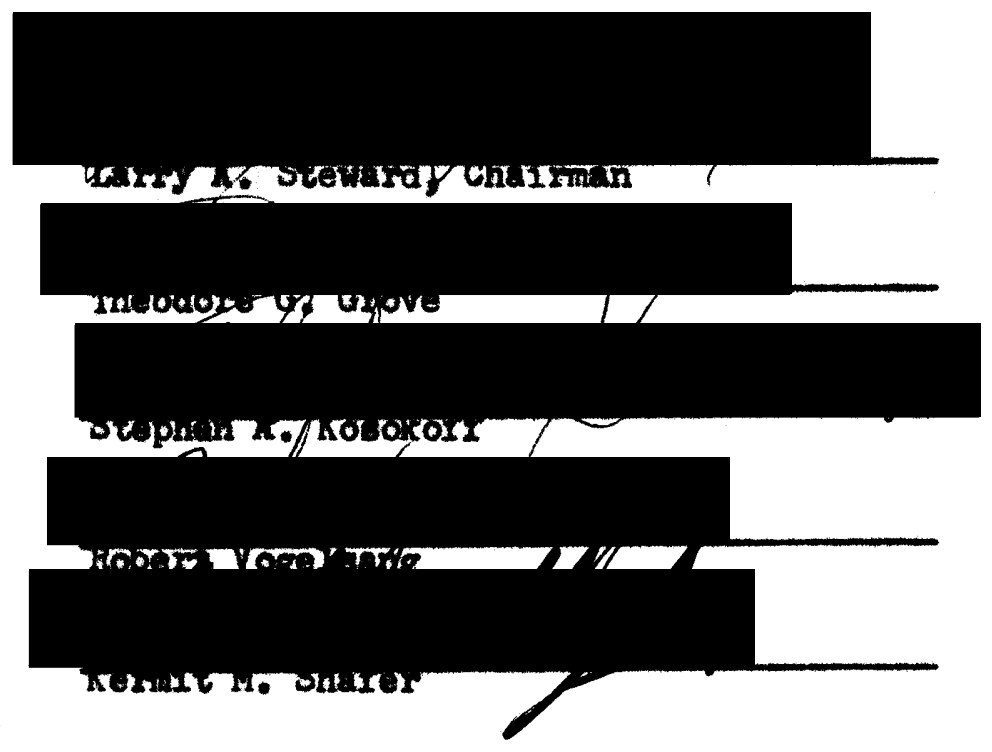

CHA PIER I

This is a critical study of the rhetorlo of SIr Thomas More and Dietrich Bonhoeffer and of plays in which they are portrayed. The purpoes is to discover whether or not the rhetoric of the playurights preserves the integrity of the 1 dese of the central charecters as oridenced by the rhetoric found in their original works.

CHAPTER II

Rhetorical orttloiem is rendering a judgment on the fltness, correctnoss or approprlateness of those discourses, spoken or written, 
the at of which is to innuace the realers or hearers. Ther is wach reriety in wothods of metorlcal criticlem. Ints study will wo the drantifutic pentad proposed by Kemeth Burte. Ite elements aro cot, agut, egency, scons and parpose. It w11 aleo enploy the nualing of etrategles, another term from Burke weaning sethode or att1tades. In

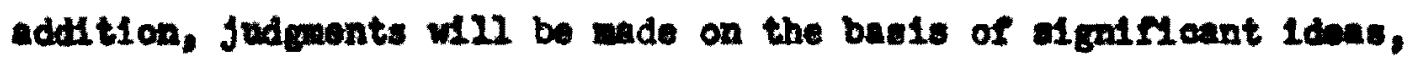
ereative choloc of Ianguege, Integrity and crediblisty.

\section{CEA PTER III}

S1r Thowe Hor was a lawer, eoholar and pablio ofretal in Englund at the the of King Penry VIT. We Inoursed the KIng'e diepleacure by his refual to eapport his in his efforte for a divores. Hi bolleved atrongly in the nood to proserve one's integrity by coefins

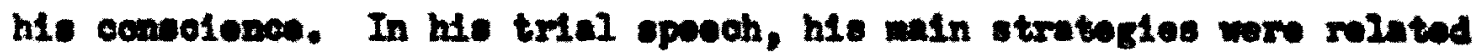

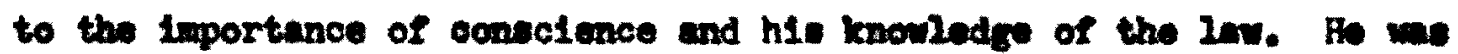
pronouned guilty of treasen and executed.

\section{comprer IV}

In 1 Men for 21 seceas, the playmight has aned crerel theatrieel etrategles that help to focu attention on Fors, the outral

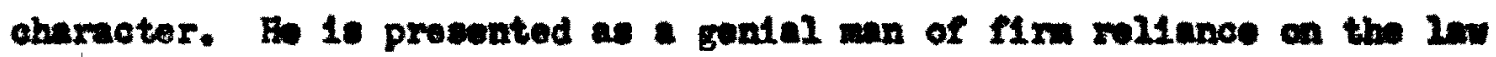

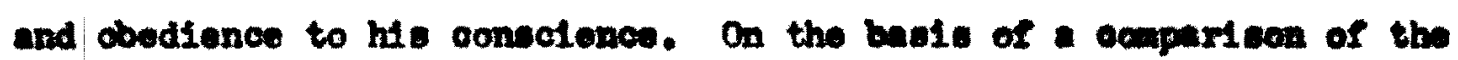
rbetoric in the play with that of More, It is ooneluded that the playwight foithelly procerved the Intogrity of Horv's Idate. 


\section{CHAPMER V}

Dietrich Bonhoeffer wa a thoologian, pastor and teacher of Germany durting the Nas1 regine. He opposed the Nasis on theologlenl grounde, and gradually camo to bellore that he must becone active personaliy and politieally. Fo jolned the realatance morement in a plot to aseasinate Hitler. Ho wa Imprisond and excouted. His chief mottre for action was obedionce to God. In seleoted writtings, he is seon to have a strong faith in God, and great hope for the future.

\section{CHAFTER VI}

The Cup of Trombing is a play based on the Iife of Dletrian Bonhosfor, though welng nootly flotional nowes. Agatn, the playwight uses dovices that bring out the hero's charaeter. Fis etruggle againot the Hasis is seen to Involve a compoponding otrugglo within himesif as he makes dectelons about his role in the situation. HIs falth in God and obedience to God are expresed, as will as his hope for the future. On the basis of ofntler ldoss expressed in both medie, it 18 concluded that the playwright euceseded in preserving the Integrity of Benhoefferts: 1deas.

CFRPIRR VII

The key Idea of conecience 1s eeen to have been preserved by both playurighta. A lumber of najor 1 deas were treced from the orledmal IIgare to the play, and thelr integrity was eeen to be preserved. Thereforv, 1t 1s concluded that the playwrights did preserve the Integrtt 
of the ideag of the two mon in the rhetorle of thelr plays. The major Implieation of this concluaton 16 that dran 10 an effective mons of exprosaling the rhetorio of Important hiotorical I1gures. 
THE RHETORTC OF SIR THOMS MOEE AND DIETRICH BOKHOETTER III ORTGINAL WORK AWD DRAMATC PORTRAIL

\author{
by \\ ROBERT C. HAFEI
}

A theals oubutted in partial fuleilimont of the requiremente for the degree of

\author{
MASTER OF SCIEACE \\ in \\ SPEECH
}


TO THE OFTICE OF GRADUATE STODIBS:

The members of the Comalttes approve the thosis of Robert C. Harvey presented July 29, 2971.

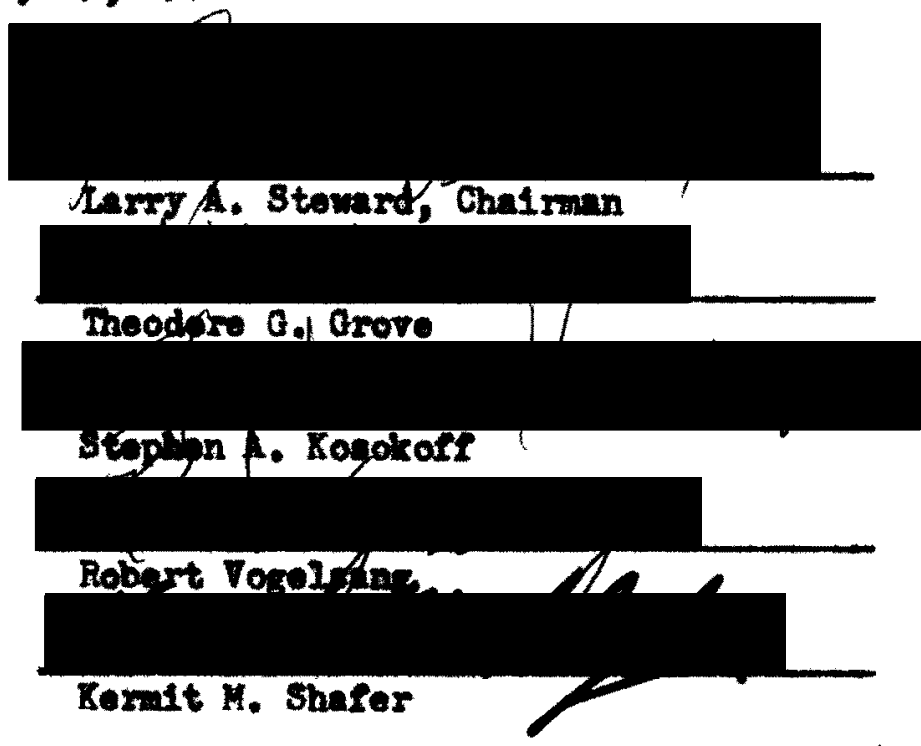

APPROVED,

Robert Tokelsghs, Elad fbopart, 3nt of Speech

Dev1d T. Clark, Dean of Graduate Studies 
TABLE OP CONTENTS

CHAPTER

PACE

I INTRODUCTION ........................... 1

II A METHOD OF RHETORICAL CRITICISH . . . . . . 5

III SIR THOMAS wORE . . . . . . . . . . . 27

IV A MA TOR ALL SERBOUS . . . . . . . . 43

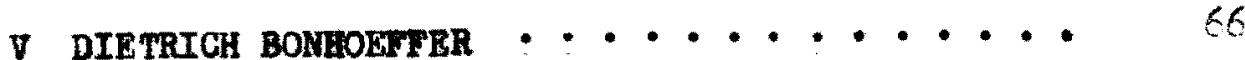

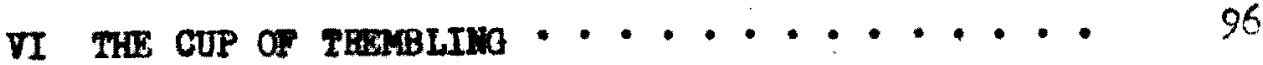

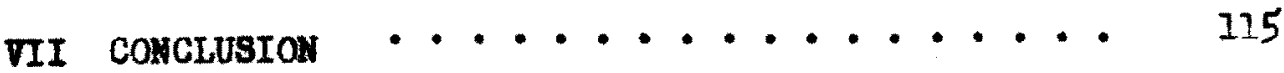

BIBLTOGRAPIY ............................... 12 ? 
CHPLER I

ITRPDTCXION

S1r Thoma Hore we a dxteenth eentury wan, DLetrich Bonhoeffer was a twentieth century man. Mors rose in offles to becows second only to the King in power and rank in Ingland; Bonheeffer hold no publle offles. More was a Romn Catholle Lymany Bonhooffor wa a Protestant olargyan. Beyond thowe differenced, however, aro a nwber of etriking almilarities. Both wore mon of deep comedtant to the Chrlatien falth, and both wre mil-trained, conpotent theologlans.

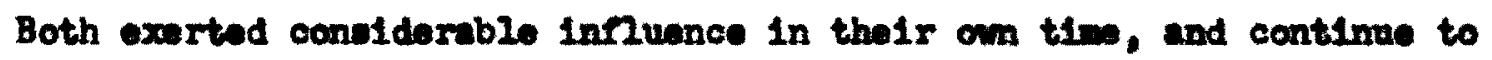
do so todey. Baeh of then can Into connict with the power flgurve of his day on the basis of his ow personul intogrity and conselence. Each of them serres as the central charecter of a play that deale with the issue of pervonal integrity verou polition expediency in the context of en authorterian gorerwant.

There appeare to be very little, if any, rhotorical analyele of the work of these two mon. A search of the four-rolnan blbllography, Morvang, ${ }^{2}$ roveale only two artieles ${ }^{2}$ comseoted vith rhotorlc, and

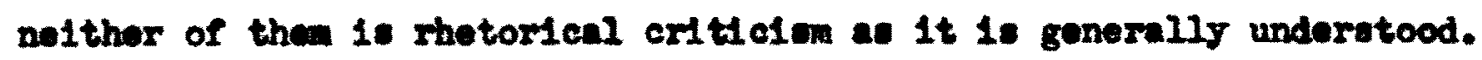
There are a nuber of works that offer Ifterary oriticiom and Inguistic study. ${ }^{3}$ Bonhoeffer has ettracted a grat deal of attention in theological circles, but non of reoord in the fleld of rhetoric. One reason for this neglect is that, in opite of the fact that 


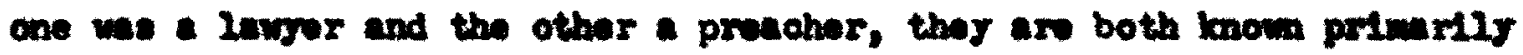

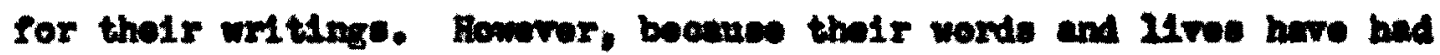
and continue to hrwe such a profound erfeot upen so wang people, the

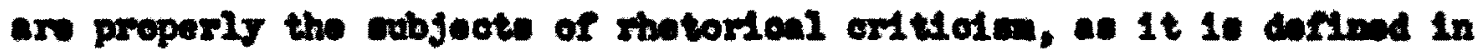
the following ahapter.

The parpose of the stody is to dotexula whothor or not the

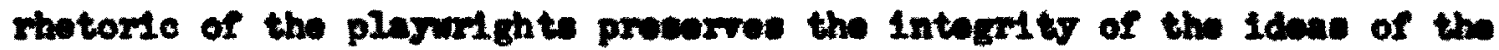

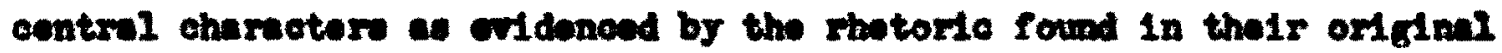

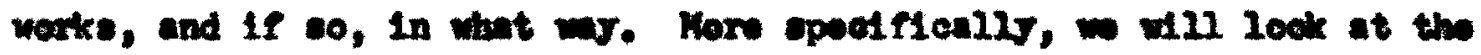
way in wioh the hiotorion figure axproeses himelf shotorioally in

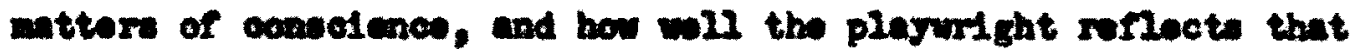
rhotorionl ouphere in his play.

To sohtere this, we w11 firet roviow sam of the relevent 11 term-

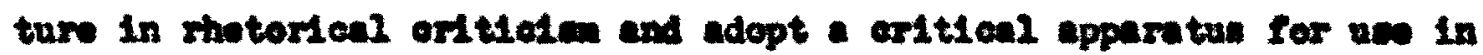

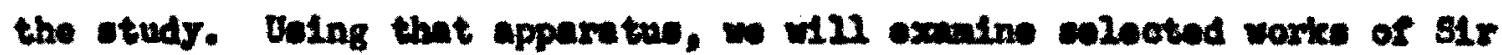

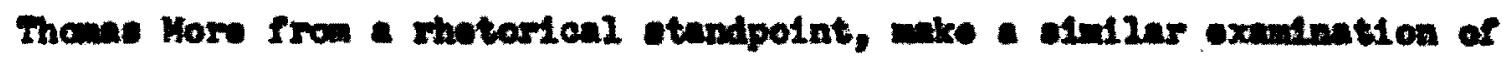
a play in wich be is the contral aringter, and ocapare the rooultant accesmonte. The ean prowdure 121 be followed for Dietrioh Bophosfer.

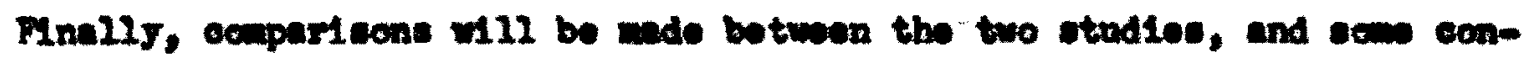
olvatoas drwon from the projeot as a wole.

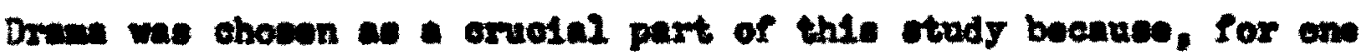
thing. Ito potontial as a Ithtorion modiun 1s often overlooked. As art, as 11terature, as ontertalmant it recelve mal-deserved attention. Playe wre orten wore than all of thoes, howner. They ars often novine

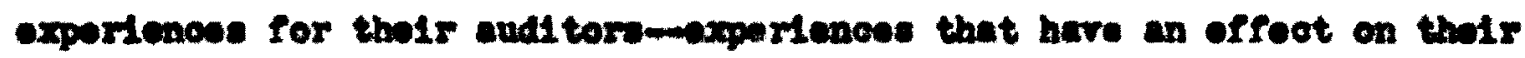

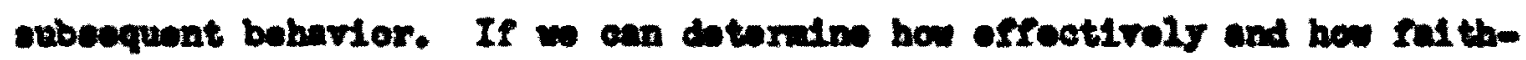


3

fully drme way be the rehiole for the rhetoric of Agniflcant persone and movemonts, we enn omploy it to bettor effoct for parouastre parposes.

Vaterial to be anelyzod Inoludes the trial opeoch of Sir Thomas Morv and other short paseages that holp to elucidats 1ts selocted portions of Lettere and Papere from Prison, by DLetrich Bonhoeffers and two plage, A Yan For 스 Seasone, by Robert Bolt, and the Gup of TroblIng, by Ellsaboth Berrythll. Othor sources will be oonoulted as Indicated to complete the nocesenry Iramowork for the atudy. 
1. Trank and Maj1e Padberg Sullivan, Yoreane (Los Angelos: Loyola Undroreity, 1964).

2. R. J. Shoeok, "Rhotorle and Iaw in the S1xteenth Century England," Studtes in Phillologx, 50 (1953), 110-27, Thomas Wilece in R. H. Bowers, ed., The Irt or Thetorie (Gelnoville, Fs.t Scholars Facoin1los and Reprinte, 1962).

3. R. W. Chambers, on the Continulty of Enelleh Prose frod Alred to fore and Fis sohool (London: Oxford toniverelty Prese, 1957), Charie: Totherbridge KIngaford, Englich Bietorienl Ifterature in the Fifteenth Century (Oxfords clarvidon Prect, 1913), et al. 
CEAPIER II

\section{A METHOD OF RHETORTCAL CRITICI8M}

miorde, words, words in orles Blise Doollttle to her highborn

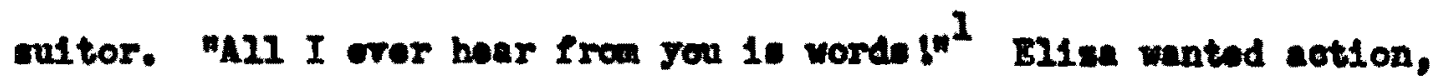
and while there met be action in humen affalre, there mast alwo be worde. They are a part of almost orery tranasction; they come at ue Irom a moltitude of courees, thoy form large part of our orn equipmont for social intereourse. Put into maningful patterne, worde are our most important mans of commintostion with ourealves, and with other poople.

There are many wees to which pat noaningrul combination of worde. Indorseh, stette and Bostrom offor a list of thirty-two worde that doveribe wht wo aro dolng whon wo opak. ${ }^{2}$ It rupresente oaly a fow of the many vorde wo unad, and contains thoes, anong otheres Inform, pereunde, 11luetrate, 111uninate, own, eot forth, rovenl, make awre of, ouggest and rolete.

Thon wo use worde in acoseloue attempt to Influence the bohavior of otherw, wh are entaring the fleld of motorid. It may be argued that

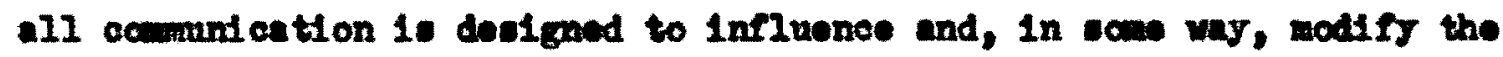
behavior of othere. Borden, Grogs and Growe, for example, etate, wone of the primary way by whioh a wan establiobs eontect with his fellow and efther achieves cooperation and antunl gain or falle into conelict and diearray is through the proose of comanteation." 3 sterone ary, 
Comanication 18 the discriminatory responee of an organiem to a stralue. ...

This definition ours thet comantoation coeurs when som enviromental diaturtance (tho stimulus) inpinges on an

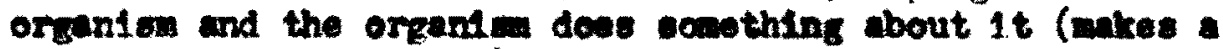
discriminatory reaponce). If the stimulis is ignored by the organtsm, the re ha been no ocmintastion. The teat is differential reaction of cone soft. The nesage that gete no response is not a scmini eatton. 4

Acoording to the defintion of metoric which will be given chortly, all comaniestion hae rbotorical eleasente. It morits the nan "rtwetore" if it is donigned for the primary purpose of pereunding

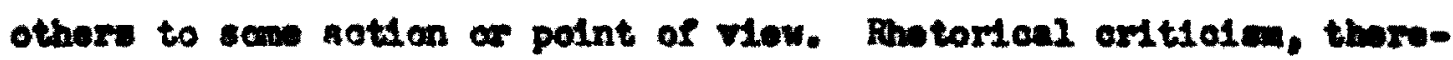

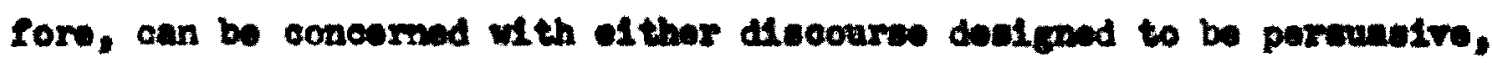
or the shetorionl elenonte in eny disooure.

This chapter wil roviow sam of the dominunt themes in the 2 tere-

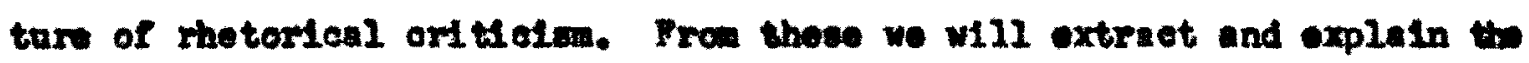
mothodologg wich 111 be uned in thic project. As we conalder variou

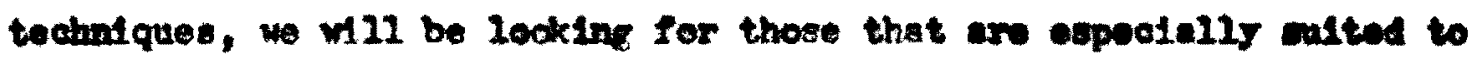
the etudy of varlety of thetorleal material. In this otudy of 31 r Thoma Mor and Dietrich Jonhoeffer, eelected portlone of orlginal wortes, both epoken and written, a wall as drumt1o portrujalo w11 be exaninad. The wathod used mast, therefore, be flextble and ecmpreheneive.

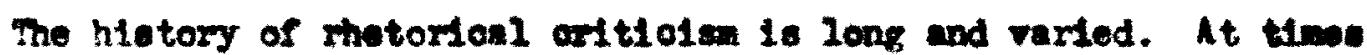

It he Roarlohed, at times it he langutehed. Tonsen, Baird and Braden point out,

The orftiofen of apeeches is oldy and yot it is now. Prato, Cicero, Quint111an, and a host of other scholars of antiquity engered in the art. Pulor to 1925, howwer, relutively fow atadents in the nodern tradition took time to formulate doetrine of thetorical oraluntion or compose critheues thet dealt urmigtakably uth the assesment of speochalking. Happliy, Iively ocaoem for epoech oritiolem is ourmently orident, es wheseed by the comuldorable number of booke an 
the aubject and the oven wor conaldarable numbr of orttiol studies of orntore and ormtory peglibed in profoentond

journale or ceperrate monographe, 5

Anong thoes who heve undertiken to go beyond the study of epeeaks In the senroh for rhetorieal devioes and the andrels of them is the oxtic, Romoth Burke. He Plade rhotorloal notives at wax in a we variety of 11terary forms. Their parpose, be otates, 10 to induce Ident1 Meation between Indiriduals and groupe. "Identiriention is af-

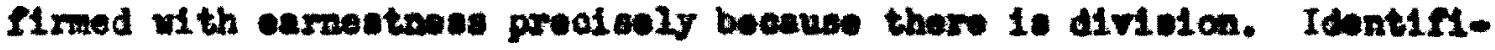
oution is compensatory to division. If mon wer not apart from oa another, there would be no need for the rhotortein to proolute their

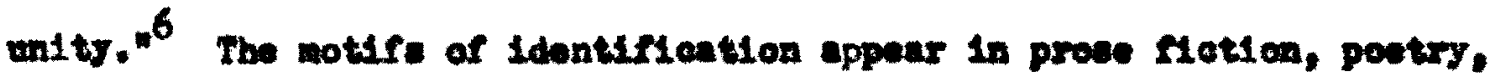

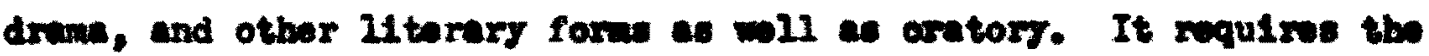

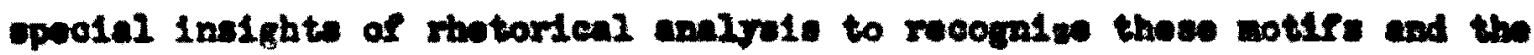
erfecte they ere deel good to have.

An Individual doos In sotanist oopote wth othor Individuile. But weth the rules of Sybolis, the individun

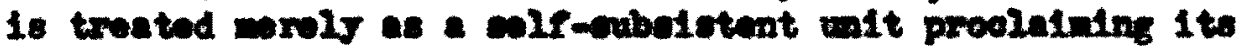
poculier nature. It 18 'at poes,' In chat its torne cooperate in modifying on enother. But incorar as the IndFran is imolved in countet 1 th othor Individuels or Eroupe, the otody of this oum individul would fall nuder the hoad of Pustorte. . O Ore need not seratinizo

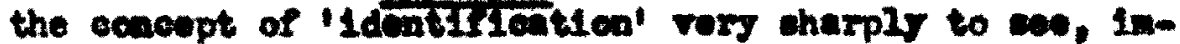
plied in it at crong turn, It 1 rendo comaterperts dirision. Rhotorio is eonoernod with the atato of Babel arter the Fall. Ite ceatiflbution to igoelologr of knomledge' muth oftein oarry we far into the lngubrious rogiens of enice and the 210.7

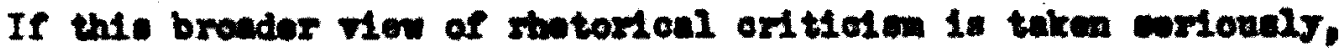

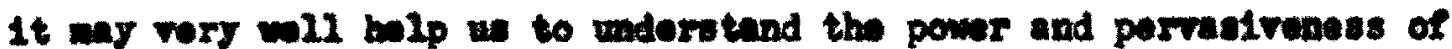
11toratare and other buan interaction in a now Lght. Heoognteing

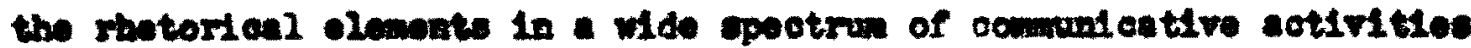


ohould charpen our incight into not only the1r basie otrueturve, but alco their etyle and sonoral improselvenese.

Any waxk on thetorienl critselw ohould prooed an the bate of

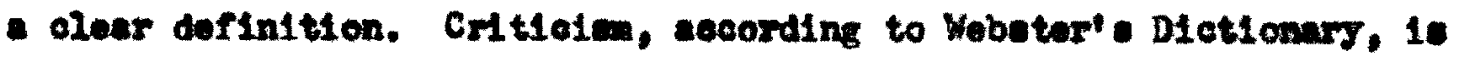
"the art of judging wt knonledge and proprtety the bautles and foulte

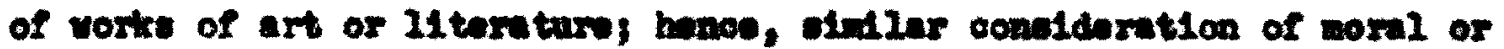

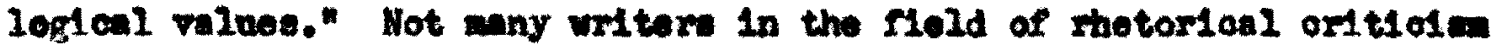

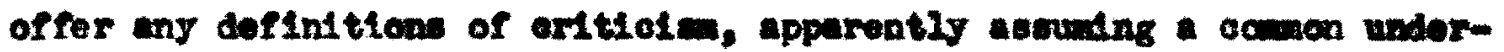
otanding on the part of thoes who are interected. The wdely airergont

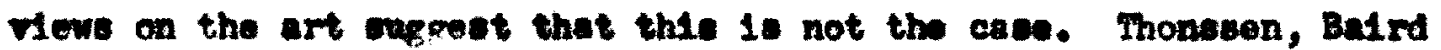

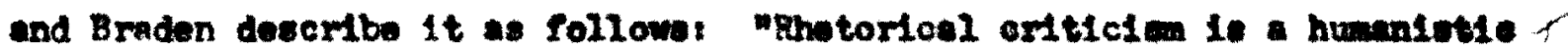

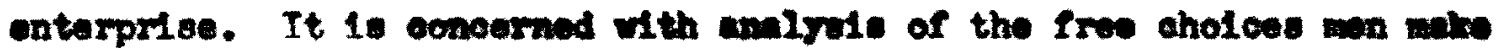

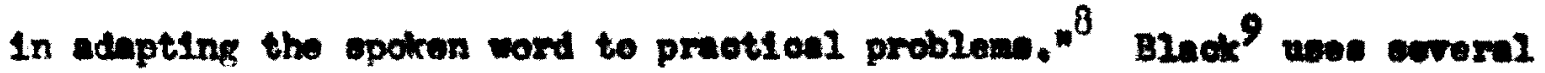
phrases that help olerify the waning of orftiolum the eritle tries

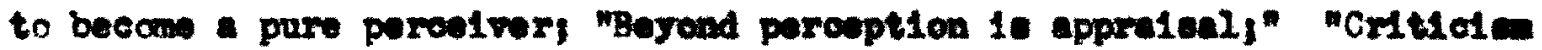

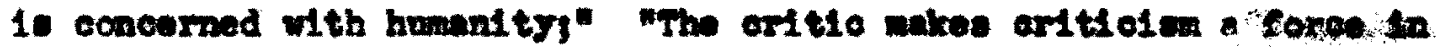

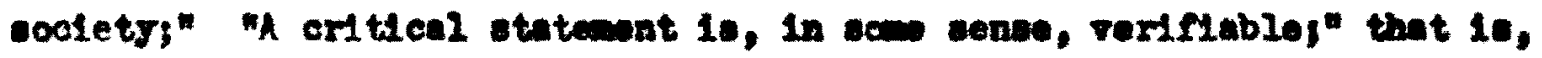
roasons can be given for 1 t.

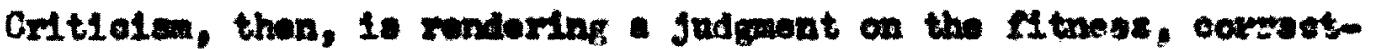
nees or eppropriatones of the objeot boing orittaleds it requires both oubjeotive and objoctive aporalonis, it deale with the oontext of the objeot as wall at the object 1tealf it makes ace of proviously extab-

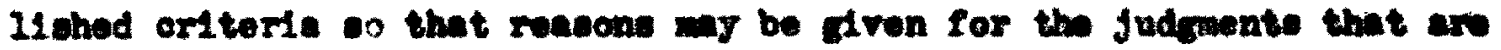
neds.

There 10 1so problem in defining thetortc, though not beoune 1t 1. not often defined. Tt is not the pavesty bat the abandines of 
defintions that caunes confuelon. Beginning with Arfstotle, nost of the major flgures in the history of rhotorical theory have offered definftions. Arlstotlo's probably forms the basis of more subsequent dofinitions then does any other. It is: "Rhetoric may be defined as the faoulty of observing in any giron the available moans of persuasion. ${ }^{10}$ This is wdened, though not substantially altered, by N1chols: "I take rhetorio to mean the theory and the practice of the verbal mode of presenting judgment and choice, knowledge and feeling. " 11 Judgment, choice and feeling all presuppose some sort of value expresafon, which would have as atated or unsteted focus the recommending of the thought or action to the hearer; in other words, persunation. Presenting knowledge ean be done without any intent to allude to ralue expresaton. About all this definition adds to Aristotle's, therefore, 1s an Indication that rhetoric need not be confined to those situations In which change of attitude, poeftion or action 1o conselously and openIy adrocated.

Black eltes Bryant's definftions ". . Rhetoric wast be understood to be the rationale of Informative and masory discourae both opoken and written, ${ }^{12}$ and basea his om upon 1t: "Rhetorlcal diocourses are those discourses, spoken or writton, whith alm to infinence men. ${ }^{13}$ Brockriede ${ }^{14}$ moves in a comowhat different direction. "Rhetorlo," he ans, is "the study of how interpersonal relationehips and attitudes are Influeneed within a situational context. . ." Perouasion 1s otill foeal, but the context of it has been broedened to include a wide range of human activities. We may assume that any of the arts might be uad rhotorleally under thle definftion; oertalnly non-rerbal comanication 
eculd be 00 ued. While this may be too bread to sorve datint tive parpeses, It reminds we that there are wany factors other than rerbal

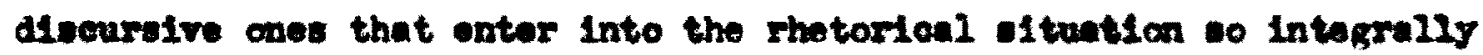
that thay wast be concldared to be rhotorical.

Kenmeth Burke ang: "For thetorio as wats 18 not rooted in eny past condition of huma coolety. It is rooted in an eneontial funotion of Ianguge 1tself, a runotion that is wholly realiette, and is eontimu-

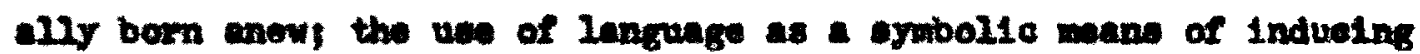
cooperetion in belinge that by neture reopend to eybola." 15 "Induelng cooporntion" is a poramatre cotivity. "The use of Innguage" enggeste

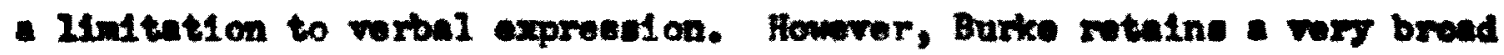

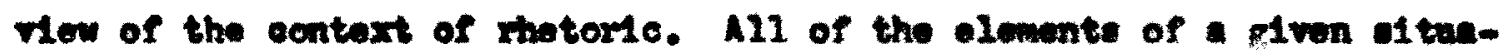

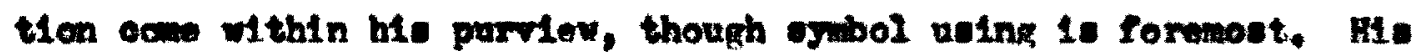

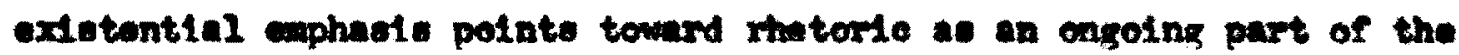
hruan eltuation, rather than an ieolated, poessional funotion. the dafinition of rhotorie wioh will be veed for this imvertigetion is basenly that of Black: thotorle is the rationale of thoes discourees, epoken or mitten, the atm of which is to Influonce the

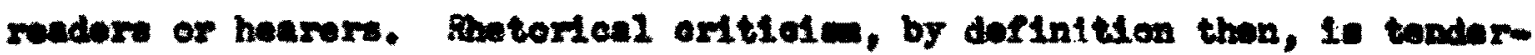

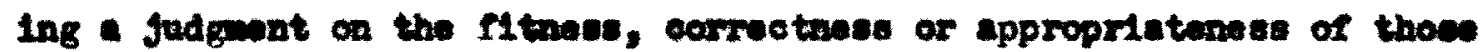
disecarves, epoken of written, the aln of which is to influenoe the renders or bonrers.

It should be alear that the uses of rhotorion eritlesen ax mach brower then pareing fudgunt on apesohes. For one thing, it is helprul

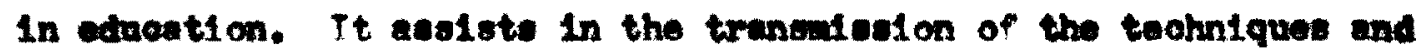
traditions of catetending perwadive diecourse. A disoiplined, eritienl 
approach to rthetorlo makes poselble the analyals, compartson and oontrat, and expative langining that are roquired for improing an art. The grost spackere hrwe been those who atudied thalr art, and wo oan loarn frem them If wh have the noceseary orftical toole.

Th1. Inpl10e a relettanohip betwoen shotorioul preotice and thatorlcal thoory. Probably no ane over boeam a truly attatanding opoaker by following motloulowely orery dotall of som thoory of thotoric. It io of the very eseence of art that an Individenal wat bring to it hle own

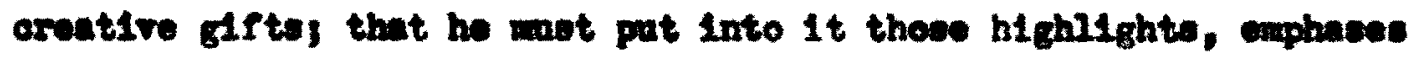
and otruoturinge that are poovliarly his own. Howmer, be dow so on the basis of a sound moniodge of mat is bost in the field. It 1o this

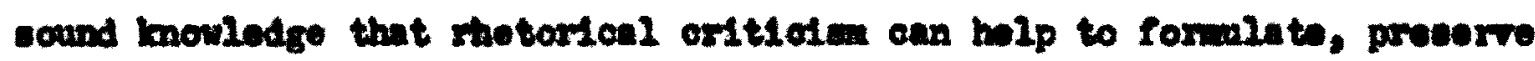
and tranimal.

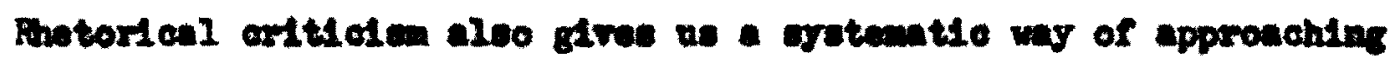

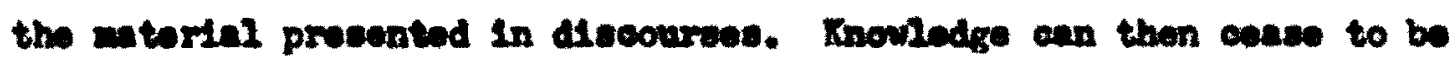
haphasard bits gleaned here and there, and be reduced to recognisable and ropertable forms. A great doal of information 10 presented in var-

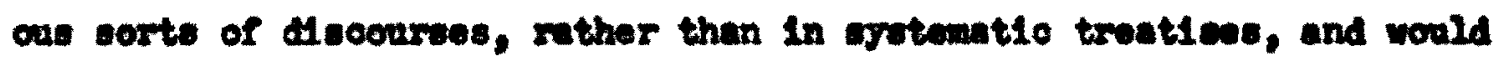
be subject to sovere attrittion if there wore no my of gathering it into

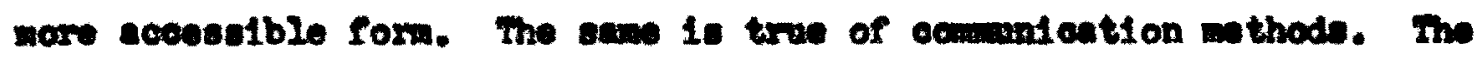

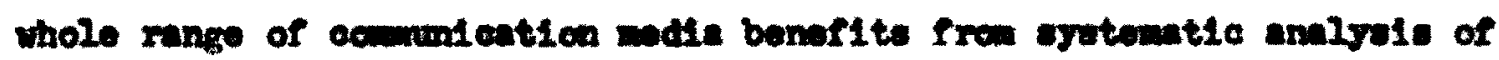
wateriel derived from eritieal investigation. What, for exenple, is

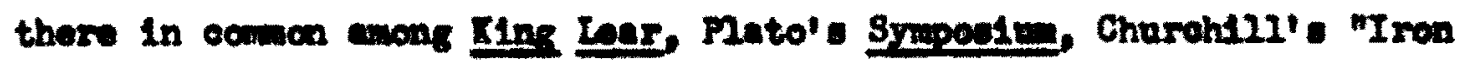
Curtain Speeoh" and the ompalgn opeoches of Sp1ro Agnow? Is thane ocmen21ty in what 18 eald and how 1t 1s ald? Are those important differenowe? If so, what factors may be wald to socount for them? which 10 
nore effective? These are anong the questions that w1ll be asked later In this study of the rhetoric of S1r Thames More and Dietrich Bonhoeffor. They are not Idle questions; they are the kind that make rbetorical orlticisa a channol to organized information from the vast world of dis. coures.

In addition to these, another nse 1 a to deteralne whet hiatorical trends are active, either in rhetorical theory and prectice itealf, or In the subject watter of rhotorion discourse. Thus, while beocming informad on the course of the history of influentlal discouree, one can aleo 11 ludinate the vider hiatory of the humen affalrs with which the discourses deal. As Wichols says, "I asenme that the theory of rhetorlo has something to do with the logleal, emotional, and ethical dimensions of language, and that alose exarination and atudy of these disonsions would be eminently rewarding in the mderatanding of human nature."16 The mater of mothod in rhetorical cxiticion is even more diffuee than that of definttion. All sorts of suggestions are wade by rhetoriclang and others as to what constitutes adequate rhetorical criticiom. Thero is strongth, however, in this rery multipliolty of poselbilities. For one thing, it testifies to the fact that rhetoric 18 dynamic and artiatic. "To ay that criticiam cannot be formulated in adrance is only another way of eayling that rhotorlo belongs to the humarities and not to the natural selences. 17 Just as the opeaker or writer who would be gonuimiy moving wut put sonething of his unique personality into h1: discourse, so the whetorlcal eritic mut be able to deal with it as - unique oreation, and not as anothor model from a universel mold. For another, this mitiplicity allows the oritic to select from a wide 
variety of techniques those that are most sulted for his particular tack. Black ${ }^{30}$ I1ste three maln approaches to the aubject: movement study, payohologionl study, noomirlatotalian study. The first uess "tochniques fashioned for the analysis of argiment on a large acele; for wdening the scope of the rhetorical critic from the individual porformance to the areep of a persuastve campaign. ${ }^{19}$ A statement from Burke ${ }^{20}$ may serve to characterlze the kind of thinking behind the pryoholopioal otudy "Al for the relation betwoen '1dentification' and 'perevasion's wo might well keop it in mind that a opokker perouades an audience by the use of styliotio 1dentifications his act of permuation may be for the purpoes of causing the andfonoe to fdentify 1tself with the opeaker' Interestes and the opeaker drawe on Identifiontion of Interests to eotablioh rapport betwoen hiwaels and his audience." Thonseon, Baird and Braden furnioh a good example of the noomriatotelian

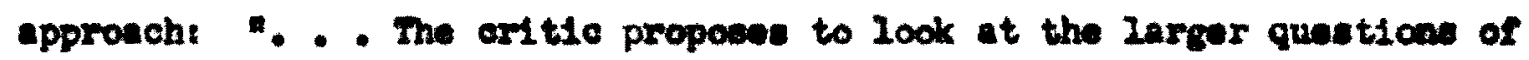
social reality . . as the opeoch relates to itmend to investigato not only the moans by which the addreas is acooupliahed, but also the onde and purposes which it is intonded to aerve." 21

Bleck then notes arwen's throe conetitrent parte of oritioien, 22 hiotorical, ro-creative (approhending wat the artiot has actually wecoeded in expresolng), and fodlefer (1ts value). The thon asesto that the noo-hrletotelians cannot remarente beonues they are too objeotive, too ooneernod with the imnodiete context. ${ }^{23}$ Fo belleves that noodr1etoteliand an "allowe no place for the porsonal revilatione of the orftici" ${ }^{24}$ and that "hristotelian eritielsan has a narrow view of huma behavior. 25

Fis orm mothod 1s to analyse rhetorical tranesotions in torma of 
otratogles, situntiono and effecte. "h orftio's melyals of a shot-

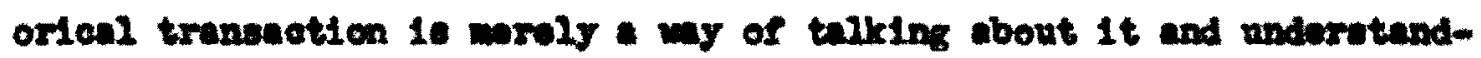

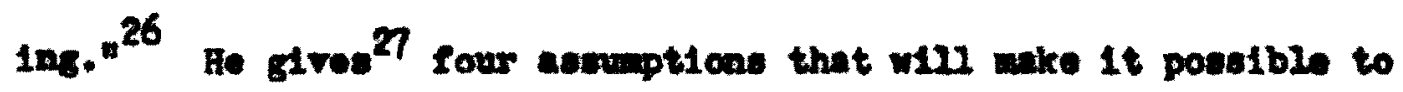
plece rhetoricel evaluntions on a ecale. Thoy aret

- . There will be a lidted maber of ware in thioh rhotorioul st tuations on bo oharmeterised. . . Thero will be a fint te nuber of thetorlesl otratogles araliable to a rhotor in any ciren oltwation. . . The securrones of a given eltuntiomal type through hietory all provide the or1t10 with information on the rtetorteal zopponese arailable in that situation, and with this inforsution the orftele can better undoretand and creleate arg opecifte rbotorleal diseoveres in which he my be intorvated. Coegrugations of rbotortionl diseourwes will form, but will be artitrary.

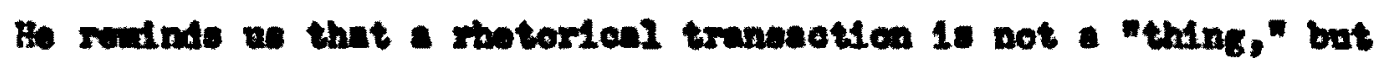
- procens. Oiven this and othor ocmplicating factore, wrilunting discerrse on a senle will not be cany or oxect, but it will yluld a larese anowat of holprul information. He dves two rulee for oritical viltings miret, oren though a otatement way be 00 framed as to appear to be about only one constituont of a rbstorfeal transaction, the statanont must really epply to the character of the wolo traneaction. Socond, eran though a statement wy be 10 framed se to appear to be about a otable ontity, the statoanat mast, in som way be applicable to a prom sees if it is to be elenirioant for rhotorloul tranasotions. "28

Bleok has bean disowesed at langth beanus be ropresonte a foros-

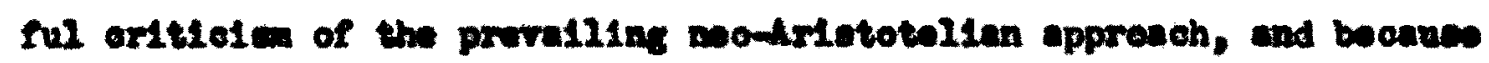
he gives ade belprul ouggontions in the dirsotion of another mothod.

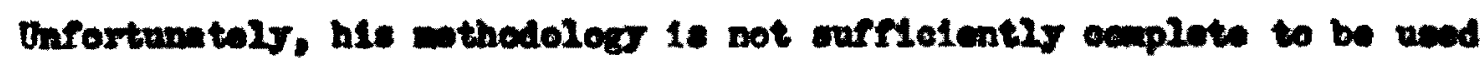
as a Ingle wethod.

monsesn, Balyd and Braden have produced a very orrtamatio and 
comprehenolve treatwent of rhetortcal criticiom. Mostly waing Arlototelian categorles, they give stop-by-stop wethode of analyzing and criticleing apenches. For example, the three essential elemente of the rhetorical eltuation are 29 1) apeaker or commenteator, 2) medim of expresalon, 3) reciplent of message. The three stages in the oriticel procese are 1) a cearching examination of the facts relatIng to the particular apeech, 2) forwulation of oriterla by which the speech ts to be judged (derived from accepted works on rhotorio and the oritic's interprotation of thair contento), 3) critical eraluation of the data. ${ }^{30}$ They are concerned primar1ly, though not $00102 \mathrm{y}$, wth the effect of discouree. My means of analyels and synthests, the oritic hopes to determine the effoct, imediate and/or long range, upon the particular audience and soetety. The word 'effect,' or 'response,' 1s signtficant. It expports a oentral reason for rbetorical oritiolom. "31 For loges and pathoe they give long ohookllots of oriteria that way be need for fudgant. For ethos, they are nore goneral.

Thonseen makes additional coments eleowhere ${ }^{32}$ thet add a rooreative dimonation (to une Oreene's phrese) to his oritical wethod, opecifically in these two questione with their implied recomendation of afrirwative aotion: "Do our orfticleme wake Intervesting resding? Are we capturing the llving presence of the orators we oralunto?" Doli ${ }^{33}$ offore this oriterion: ". . ortiticlsing the truth of a speaker's ph1losoph10 asormatione should be the vitimate objective of apeech criticiem," Fisher ${ }^{34}$ and Holland ${ }^{35}$ edopt Burte' catogories of motives and otrategies. In dofining stratogies, the lattor writor says, ". . the orlt1e would do woll to consider atretegry as eynonemore 
wth wathod. - . A atrategy ma be thought of as a plan of attack." 36 Sentences, paragrephe, and entire speoches have strategles, as does society in any given willeu. Burke approaches rhotorioul amlyeis dramatiation2ly through his pentadt act, scom, agent, agenoy, purpose. 37 We will say more about Burke later in this chaptar.

James T. Boulton has surmed up the responalbility of the shotorlcal critic in a compolling way:

The Idaal orftlo-of thetorioal as of all 11torary discourso-must concern himeelf not only with the 'factsi alloded to, but also with the orator' primary moaning and the oubtle suggestivenese ocmunicated by his tones the pattorns of thought and argument which somotimes reveal themselves in elearly dofinable mage but somotimes in a manner of wich the opectrer himeelf may hare been only divily amare; his 1 dien and Imagery; his eenee of the rhythm and sound of language, and of th his undoretanding of the gharacter-in the fullest senve-of his Intended audIence. 38

In short, the rhetorfcal critic must be concernod with anything and ererything that will onable him to analyse and ovaluate the permasive thscourme under discusolion.

The rhotorical oritie should not be conruead or dianayed by this plethore of wethodologioal suggestions. Pather, ho should see in $1 t$ olear orldonce that responsible orfticl am is not a matter of boving to - narron line but of gathering from a wide fleld. Fis procedure muat be consistent and comprohonelve, but It need not be limited to one scholar or one tradition. As Profossor Walter put it,

To assume that thetorical theory can rumioh a formuls complote with a step-by-otop procedure to be followed by the othervise thoughtless or tile, is likely in error. Formulas may work wil in elomentary physics, but in the humanities, forrulas sombon result in mindiess mechanicalneas, giving ovidence contimes of herd work but lese often of brtlliance. Soholarship and hard 
work are not the ano things but critlcien that is brilliant

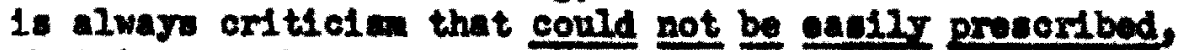
that is sanevhat umpected, thit fits the unique apeeoh for which it 1 is dosigned and perhape no other opeech, that is the most appropriate thing to say at this time about thet opesch. Fo eay that oriticten camot be formulated in advance 1 only another way of eaying that rhotorio belonge to the humanities and not to the natural oolences. 39

Unfortunately, eeleotiolem wil not eneure brillient eritlciang but eschewing rigid formulas my at least discourage wechanical oriticlen.

The methodology used in this project w11l conolet of the dramatiotic pentad, the noung of etratogies, and, where appropriate, the applieation of four atandards of good epeech to speolflo passages. It borrowe most of 1 te primary terminology fron Kenneth Burke. The dranutiotic pentad is uned becance it emphasised the relationahips that exdet between various elomonts of the rhetorieal situntion. Holland says,

For Burke, the pented does the sane thing that ' 'Orwamer' doos. That is the pentad roveale relationahspe botweon thinge or attuntions and thelr enves or notires, just as - gramar reveale the relationokip between the moaning and the atructural agpoote of angunge. 40

Particularly in a rhatorian analyate of ouch diveros weterials as the opeoches of S1r Thomas More, the sermons and lettere of Dletrich Benhooffer, and nodern pleys that deal with the 11 res of thoes two martyre, It is necesany to nes a dorlco that is flextble and that encourages the exploring of relationhips that ight otherwise go unoticed.

Burke glves this prelininary defintion of his pented

In a rounded etatement about motires, you must hare san word thet nawes the ect (names what took place, in thought or doed), and another than nemes the soen (the beokground of the act, the oltuation in whioh it occurrod); also, you wast indloate wht person or klnd of peroon (agent) performed the act, whet means or inatrunents ho used (apeney), and the purpose. Non my violently disagree about the purposes bohnd a dren aot, or about the ohar- 
acter of the person who did 1t, or how he did 1t, or In what kind of eituation he ectod; or they may oven inaint upon totally differwat words to neme the act 1tself. But be that as it axy, any ocaplete statenent about notives will offer gom $\mathrm{kind}$ of answere to these flve questlons what was done (aet), Then or wher 1 was done (esene). who did 1t, (agent), hor he did 1t (ageney), and why (purpose). 41

Burke's pentad eovert about the same points as Hechruth does when she epells out the olx aroas a ortic wat cover in analying a rhetorical ment, 40 epeaker, andionee, place, purposo, t1mo, form. The adranteges of the pentad are 1ta adaptab124ty to all rhetorieal situations, not just opeches; and 1te greater emphesis on rolationohipe betwen factors.

The pantad also has sowo affintty with Boulton's modifleation of W1112ams' question which can be pesed by the rhetorioal oritiol Why does who say wht to whom with whut efreot?" 43 Burte' sppronoh goes eonstarebly bejond thet of Thoaseen, Batind and Breden, wo new three elemonte in the speoch of tuation. 44

It wast be emphnelsed that the important thing about Burke's pented is not the torme, but the dranatiotic approuch which explores the relationshipe enong the rarlowe factore noned by the tarme.

Another Burkean term that is to be ueed is otrategy, alrady referred to as a mothod or plen of attack. 45 It 1e, of oourwe, the gpaker's mathod or plan of attack that is at 10ove. The thak of the orttlc is to nane the etrategles of the speaker. Holland aplifion her desoription of Burte's wanting by otating, whe aoourate nuing of the etrategles obriously depends upon a careful andrule of the spaker's langunge pattorn to determine what vords most realistionly nev the associative grouplng of ideas which the speaker mike in his 
Ianguage, 46

Burke intends this torm to serve as an ald to discovering what is going on in the total stuation surrounding the ovent (or act) under acrutiny. The thetorical nature of the act is derivod from wan's attempt to 1dentify with his fellows, particularly won ho is trying to Influence their bohavior, or persuade them to a point of view or course of action. Inis identification is possible because man shares a common substance. Their difision from one anothor is an aberration of their essential nature, and it is in bridging this diriston that rhotorle is born. 47 Such rhetorical ondoavore make use of a great rarlety of otrategles to bring about the desired 1dentification. Veing fanillar proverbs to 1llustrate his polnt, Burke coments on his concept of otrategy:

Proverbs are strategtes for dealing wth eltuntions. In -o far as alturzions are typlcal and recurrent in a given social atruoture, people develop nowas for then and strategles for handifing them. Inother nome for strategles inght be attutudes. 48

The nuaing of strategles is up to the arditic. How olosely he approximates the Intention of the speaker depende upon how wall he hes analrsed the total situstion. Doubtless different critic will produce different "namings" for the same strategy, but this io no different fron the variations one would find in the oritical appraisals of orftics uaing any other approach. The parpose of using the term "stretegy" is not to try to come up with the same term Burke would wee, but to got "Inolde" the matorial in a way that another approach might not suggest. It is an attexpt to take sorlously a point that was made by Boulton: 
- H111ane strueses the central and complox natwre of the rintionchip that oxdate between a miter or opeiker and his andienoe, whenover en cot of commilation takes place. To Fehtly cophastses that, whaterer the oubjeot or ooeneles of the discoures, exttioles gannot properly fuaction unlese this relationahtp is explored. 49

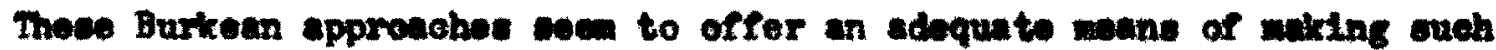
an explaration. Mis doet not proclude referense to othor sobeinre and other terminologles when these on be afted to elarify the importence of a particular elowent of the rbotorical eltuation.

So far w have been malniy concernod with the wenne of Pinding

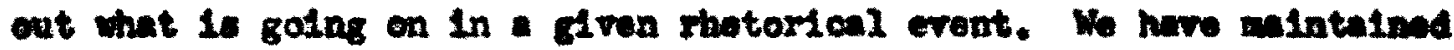

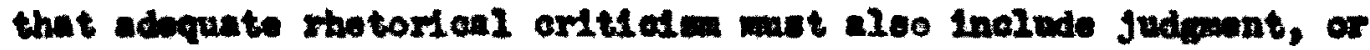
evaluation. Evaluation weot bo ocasidored in the 21 ght of all that is

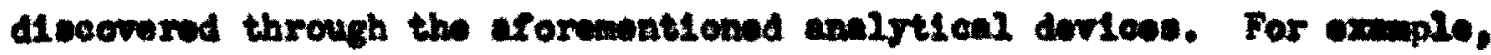

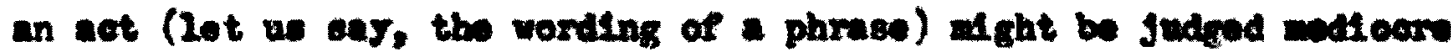
when takon out of contexty but won rewed in the soone in which it we pleod by the author, or when selated to the purpoes for inleh 1 t

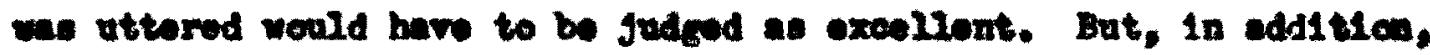
thore are four ctanderie that wil be applied to the material, wo that there an be oupariecas betreen the two pirinotple wubjeote of the inreotigation; and Judgente made on the genmen palley of thoir rhetorte.

The Arst of these etandard is thet good Alscoure should provent

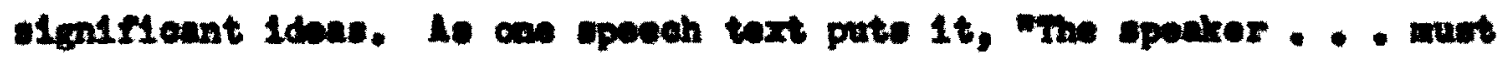

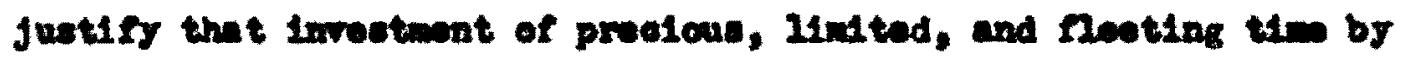
giving the audionce real mineer an information, now pointe of riow,

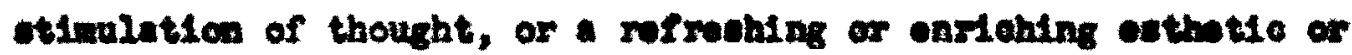
enoticanl expertence. 50 The themes of good dlecourne should be Inport tait, at loast in the eantext in whoh they are deliverod. Han of the 
Wll alvo be important fraw the leager Viev of the hietory of 1doas. They way bo baste sociel or pereonal thowes. Ordinarily, they aro 1deas viloh the 11 stenere or resders deal with in the depthe of their being; Idese that have a profound influence on thelr fundunental orientation to 118.

A second otandurd is that good discourese employs crentive oholes of Innguag. The very concopt of exeativity implies an elenont of ourprive, of finding things that one bad not thought of before. To be

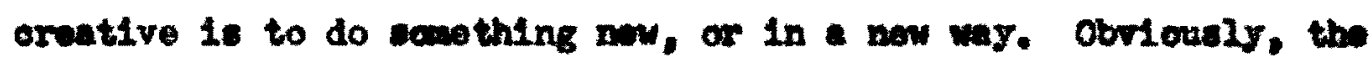

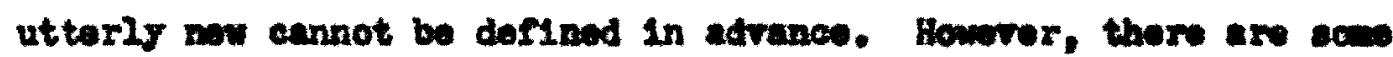
critaria which an introduce at least a modicu of objectivity to eraluation of creative languge in shetorical discouree. On enoh

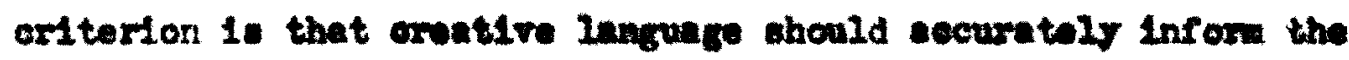

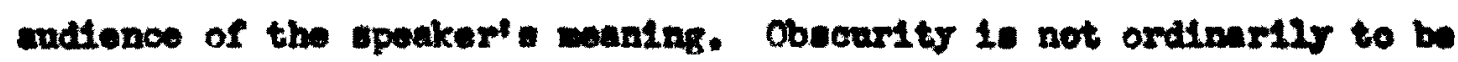

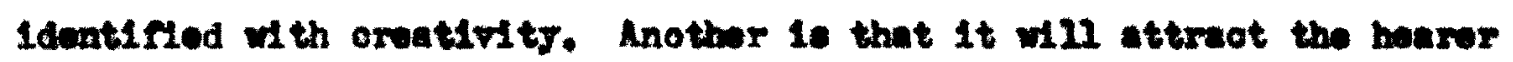

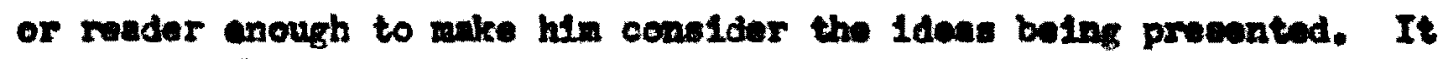
w121 Induce new way of porcelfing the moninge of the opouker. It wil bring frosh Insighte to the material preaented. It wil ut111se eambinctione of words that are atriking and that ontoh the innginution of the hearer. Croetive choloe of lenguage means that a speaker uses: - - now waje of presenting the fadilar so that his 21 etoner peroelve it frochiyl bo wes conerete woxds that onable othore

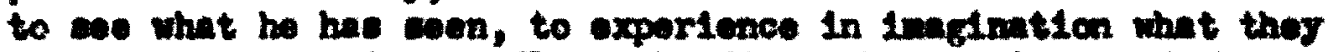
have wever known in the Noehs he flads the procteo word that dispels the fog of confusion and lends to cleaver riewe of problenef he ivvelit wht bad been hitherto Midden miationehipe. 51

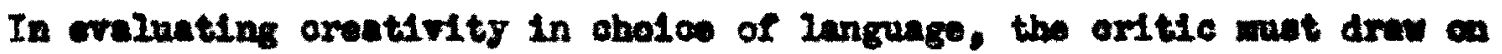
hie own exporionce vith offective otyle in addition to utilinge owoh ariteria as these, and try reponalbly to rolate it to the oubjeet at 
hand; for the judgment that is made is ultimately the reaponiblifty of the person who makes it.

A third atandard is credibility. Is the speaker believable now, and was he bellevable to his original audience? What rolutionohip, if any, exiots between the two situations? Phis standard has to do with the methode of inquiry or ansertion that are ueed, with how they are related to the entire meseage, and with the nature of the argunonte that are used to support 1deas. The critic unst exmane not only the IInes of reasoning, but also the warrants on which they are based. A fourth standard is intogrity. MeBurney and Wrage are talking about this standard when they say, "The 11stener's attitude townd the speaker 1s nnquestionbly a factor of great importance in speech. In many situations it is the artical factor. If the audience dislikes the spoaker or adstrusts hin, all else way go for maght, ${ }^{52}$ One crecial Ingredient in audienoe renction to a apaker or writer is the way in which they peroeive his integrity-whether or not thay belleve hin to be bonost in dealing with knom dats, and consistent with what they know from other contexts to be true of him. This is particularly true of such men as S1r Thouse More and Dietrioh Bonhooffer, for whon fidelity to conacionce is a key oharacterietio. The way in which thelr integrity 1. percelved is oructal to the over-all aseesment of their rhotorle. The foregoing critical toole-me four standarde, the naning of otrategles, and the dranetistic pentad-will be used for this researah. They will be applied to the seleoted woxks of S1r Thonas More and Dietrich Bonhoeffor, as wil as to the plays that deal with then. Through the we of these tools, we can assess the nuture of the1r rhetoric, trace It from one wediun through another, and discover whather or not the play- 
wrights falthrully renlect the rhetorical effectiveness of the men themeelves.

It 1 s to be hoped that these gutdelines will be servants of the writer and not nastersy that there w111 be roos to account for the unexpeted and Iiberty to aceept the exception. When important metorical elements that elude these classielcations appear, they w1Il be noted and diecuesed in the most approprlate way avallable. 


\section{Mores}

1. Lerner and Lowe, My Falr Lady," Info. n.a.

2. EII zabeth O. Andorsch, Ioren C. Stats, Robert N. Bostrom, Commanteation in Everyday Dee. Third Edition (Now York: Holt, Rinohart and Wineton, Inc., 1969), p. 25.

3. Coorge A. Borden, Rahnrd B. Gregs, Theodoro O. Grove, Speeoh Behavior and Frman Internction (Englewood Cliffs, Hew Jersey: ProntioeHall, Inc., 1969), p.1.

4. S.S. Stevens in Konneth $\mathrm{K}$. Soreno and C, Darid Morteneen, Foundetions of Communication Theory (New York: Harper and Row, 1970), p. 20.

5. Lester Thonesen, A Cralg Balrd, Waldo W. Breden, Speech Criticlan, Third Edition (New York: The Ronald Press Co., 1970), p.4.

6. Kenneth Burke, A Bhetoric of Motives (Berkeley: Dnivereity of Celifornta Press, 1969), P. 22.

7. Ibld., p. 23.

8. Thonsaen, Balnd and Braden, gp. elt., p. 29.

9. Eduln Black, Rhotorlan Critiolem: A Study In Mothod (Now York: Meamilian, 1965), pp. 5-7.

10. Arlatotle, Bhetorlc, $1355025-30$.

11. Marle Hochmuth N1chols, Fhetorle and Critlelism (Baton Ronges Lout siana State Untreroity Prese, 1963), p. 7.

12. Black, op. clt., p. 11 .

13. Tb1d., p. 15 .

14. Wayne E. Brockriede, "Diwensions of the Conoept of Fhetoric," Gurterly Journal of Speech, rol. LIV (1958), p. 1 .

15. Burise, op. c1t., p. 43.

16. Nichols, op. att., p. 13. 
27. Ot1a H. Walter, "On the Variatioe of motortoal Critiefin," in

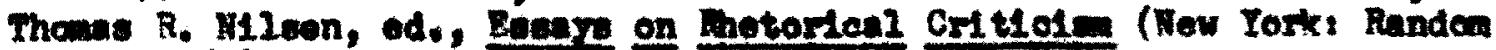
Forea, 1968), P. 170 .

18. BLaok, ge. git., pp. 18-19.

19. Hoid., p. 20.

20. Burke, g. aft., p. 46.

21. Thonesen, Balrd and Bradon, ge, gt., p. 12.

22. Black, og. 요t, pp. 36rf.

23. Ib1d.. pp. 49re.

24. Ib1d., p. 76 .

25. Toid., p. 214.

26. Io1d., p. 235.

27. Ibld, PP. $1339 \%$.

28. TbId.: Pp. 235-6.

29. Thomown, Bald and Breden, gq. e1t., pp. 6re.

30. Ibid., p. 11 .

32. Ibid.

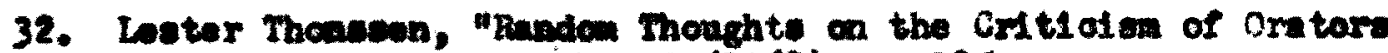
and oratery," Wetern Greph, val. 32 (1968), p. 185.

33. Oeorg W, DeII, "PhILewophto Judgante In Contenporery

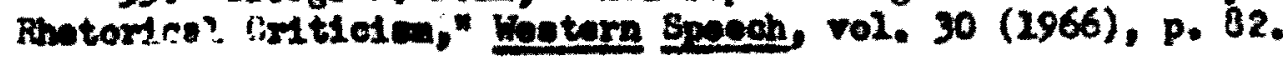

34. Walter R. Flaber, HA Hothe Viow of Comantontion," Guarterly Jourmal of Speech, rol. Iti (1970), pp. 132-139

35. Virgina Hollnd, "Rhotorioal Critlalent A Burkean Mothod," Ganter2y Joarme of Specel, vol. XXXIX (1953). pp. 444-450.

36. Told.: P. 445 .

37. Kennoth Burke, a Gremar of Motspes (Berkeleyt Dnfreralty of callfornte Preas, 2969), $\bar{p}, \mathrm{x}$.

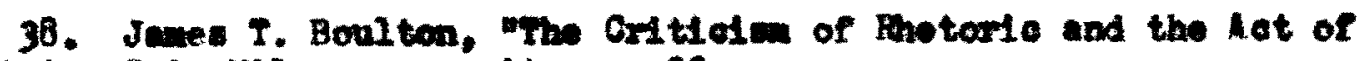

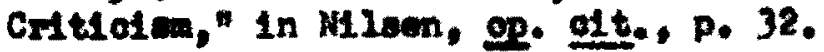


39. Walter, 100. eft.

40. L. V1rginia Holland, Counterpoint: Kenneth Buxke and Aristotle's Theorles of Phetortc (New Iork, PhilosophIeal Library, 1959), p. 61.

42. Burke, Gramar, p. xv.

42. Mar10 Hochanth, A Hilotory and Critioian of American Publ10 Address, vol. IIT (Now York: Longuans, dreen and $60 ., 2955$ ), $\frac{190.9}{9}$ fr.

43. Boulton, op. ㅇt., p. 30.

4h. See above, p. 8.

45. See above, p. 9.

46. Hollend, "Rhetorical Gritlcien," p. 446.

47. Soe Burke, Phetorlo, pp. 19-23.

48. Kenneth Burke, A Ph1200ophy of Literary Form (New York: Vintage Booke, 1957), p. 256 .

49. Boulton, og. elt., p. 30.

50. N1m Johnson Sirett, Lew Sarett and William Trufant Foster, Baste Prineiples of Speech (Bostons Houghton Mifriln Co., 1966), p. 37.

51. Told., p. 40.

52. James H. MaBurney and Emest J. Wrage, The Art of Good Speech (New York: Prentice-Hall, Inc., 1953), p. 43. 
CHAPTER III

SIR THOMAS MORE

On Tresday, July 6, 1535, Str Thomas More, Kntght of the Raalm, formerly Lord Chancellor of England, long-time friend and confldante of KIng Honry VIII was beheaded for treason on Tower HII in the City of London. This event was groeted with conoldermble diamay in Fngland, and perhape even more abroad. 1 For Thowa More was ganerally acknowledged by his contemporarles who know the literary and polltical scenes to be ons of the flnest men of his or any age. Plobert Whittinton wrote of him,

Hore is a man of an angel's wt and singuler learning. I know not hts follow. For where is the man of that gentleness, lowliness, and affability? And, as time requireth, a man of marvellous ifth and pastimes and sometime of as and gravity. A man for all soasons.2

Behind that expcution lies an exciting otory of intellectual and political adventure, and within it are elements of persuasion that should be of great interest to rhetoricians. The act that is central to our Interest is SIr Thomas Moro's refusal to take the oath of eupremaoy because his consolonce forbade 1t. In connection with that refusal arv several erents of conequence for this study, particularly More trial and the speech he gave on that oosasion. In uning the dranatiatio pented to analyse the act, will look at the following elements: the agent, Sir Thomas More; the seene, Sixteenth Century England and the Imediate environs of More's career: the purpose, Morv's determination to obey his consclence; and the agency, sowe of his worde, primarily his 
trial apeech.

Thomas More was born in February of $1478^{3}$ to John More, a 1awger of London, and his wfe Agnes. He Iearned Latin at St. Anthony's School, and was sent at the age of twelve or thirteen to the household of Archbiohop (1ator Cardinal) John Morton at Iambeth Falace. Th1 kind of servitude was nomial for boys of that day. In the houses of great mon they learned the $x$ ind of manners required for progreasing in ooclety and in their profeselons, or at court. They also, if they were bright and congenial, earned the influence of their hoets when opportunitles for advancement came along later. Certainly Thomas was bright and congental onough, and Cardinal Morton was his good friend throughout hie 11 .

More was sent to Oxford Intrersity at about the age of fcurteon. The University vas scholestic in emphasis at that tim, 4 so Thoalas would have continued his atudies in Latin, using it for his work in gramar, rhetorlc, logic and dimectic. He remained at oxford for about two jears, at the end of which he was adnitted to New Inn. The Chancery Inns, of which New Inn was one, were preparatory training sohools for Joung men who were preparing to practice law. From them one went to one of the Inns of Court, and Thomas More was adinitted to Incoln's Inn on Pebruary 12, 1496. Along wth his study of 1aw, he found time to study Greek and theology, eapecially the early Church Fathers. He also began some frlendships that had a profound influence upon his, and to whioh he was to contribut Immenoely. Among these frlends were Deaiderius Erasmu, John Colet, WIIIem LAly, W1111em Orooyn and John Fishor. Indivdually and together, they represent the flnest acholarship of the period. They 
atimulated the love of learning and writing that helps to acount for the Importance of Thomas More to Ingland and to the history of 1deas. It 1 important also to remember the very great influonce that religton had in Fore's 11fe. Te serlously considered becoming priast, but decided that his desire for a wife was stronger than his religious callinf. 5

More married Jane Colt in 1504 or 1505 , and they had four childrent Kargaret, Mizabeth, Coelly and John. Jane died in 1511, and within a month, More remarried. 5 ats second wfe was widew, Alloe Middleton, and was six or seven yeare older than Thamas. She proved to be an excellont menager and good mother to More's ch1ldren we well as to her on daughter. That she was comowhat cutspoken and not altoge ther sympathetio to all of More's intellectual intereste seenes pretty generally accepted.

More's natural uit and Intelleot, and his great learning openod up rapld progress for his in his chosen profession. His eon-in-1an,

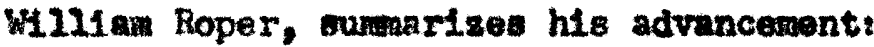

After this he was wade one of the tuderaberiffe of Lonton, by which offlce and his learning together (as I have heard him say), he gained vithout grier not so 11ttie four hundred pounde by the year, alth there was at that time in nowe of the prince's courts of the lawe of this realu any matter of importance in controversy wherein he was not with the one part of counael. of wom, for ht learning. Hedom, knowledge, and expertence, wen had such eatimation that, before he came to the service of KIng Henry the Fiphth, at the oult and Inetance of the English merchants, he was by the King's coneent made tutce ambassador in certain great cauees botween them and the merchente of the Steelyard. Whose wiee and disoreet dealing thervin, to his high comendation, coulng to the XIng' a undaratanding, provoked his highnees to cause Cardinal $\mathrm{Helsey}$, then Lord Chancellor, to procure him to his serviee. 
Roper aleo tolle us of the dolight that King Bonry and Guen Catherin round in More's company. 9

By the the be cane to tho KIng' service, More had publiched a sood many vorees, hiotory of the relgn of Rlohard IIT, and hil famous Utog1e. In a nont umubul way, he oonbined the vort of a ooholar with the buay I1to of lewyer and, Intor, a nember of court.

At this point we wat oupply part of the soene gatnst which the egent. Thowas Nore, carried out his actions. Arthur, heir to the thron, wa married to Cetherine of Aragon in 1501, bot died alx monthe later. Vpen the death of Henry VII in 1509, the eeoond son, Henry, becane Rins Henry VII. Shortly bofore his coronation, he was marrled to Arthar': roung wdow, Cathertae, in arder to presarve the thes that had boen eatublishod between Fingland and spain. Since Catherlne had boen married to Honry' brother, a papal atepensation was required to regularies br

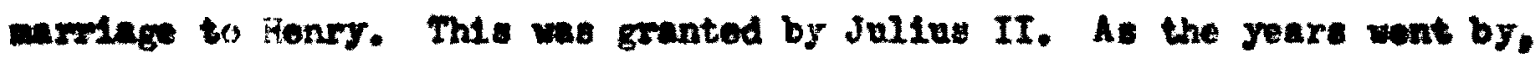
a rumber of sons were born to Catherine, but 11 of then were elther at12-bom or died Imadietely after birth. In 2516 a daghter wae born and 21ved. But there were ot1L no sons, and the King began to think about diforce. Sostlle relations with Spaln and a growing passion for Ame Bolegn made woh a divoroe Inoreasingly attraotive. Moreorer, Fenry beoam comvinoed that, in spite of the papal diepenation, he hed almod In anrying his brother's widew and was belng punishod by ood by bolnc donted sons.

Another papal action we sedeht, this time to set abite the mariage to Catherine. The pope coneldprod the ther for wown rats, and thon seld no. In the montine, the "KIne' nat ter" wa the burning 1asu in Freland, cocupring the conter of attation in alnost overy 
national and international matter. Henry docided that the pope was only the bishop of fiome, a bishop among blehops rather than the supreme hoad of the church, and therefore had no authority over the King of Fingland. He sought the opinion of people all over England and the continent, and, not surprisingly, most of it was ferorable to himself. Sir thomas More told him very early in the discussion that, in his judgment, the original dispensetion was valld and could not be put aside. Neter that More carefully refrained from taking any part in the debate. Blohop John Fisher publicly and persistently made known his opposition to the King' $\varepsilon$ action.

Cardinal Woleey, then Lord Chancellor of England, was doing his best to secure an outcome favorable to the King. He was also doing hie best to become Pope. He was unsuccessful in both cases, and w8s remored from off1ce in 1529. He successor was S1r Thomas More.

It is intereating to conjecture about the reasons for Henry' appolntment of More, knoulng More's attitude toward the dirorce. For on thing, More was an excellent furist. For another, Henry may have felt that he had better chance of changing More's mind $1 f$ More was in thie postition so close to the King, physically as well as influentially. Henry clearly intended to here his oun way, and probably could not Imagine that More, whon he had befrlended so consistently, would not eventually come around to his slde, particularly if he held the secondhighest office in the realm.

Mare wisely spoke to no one but the King about his vlews on the divorce. Henry began to push for legislation that would solidify his position on the succession, and on his position as head of the church. 
When the Convocation agreed with Henry that bishops should no longer have the power to selze heretics, the King was well on his way to obtaining the power he desired. The day after that action was taken, May 16, 1532, More resigned as Lord Chancellor. 10

An additional force that exerted great pressure during these crucial years was the stirring of reform in the church. People other than Henry had disavowed the supremacy of the Pope. England was continually recelving Protestant ideas from abroad and from some of her own clergy. Many of these ideas fitted into Henry's various schemes, and complicated the issues for conscientious churchmen such as Fisher and More.

Archbishop Cramer, one of Henry's appointees, granted Henry a divorce from Catherine, and he was married to Anne Boleyn on May 28, 1533. Their daughter Elizabeth was born soon after. Parliament met in January, 1534, and passed the Act of Succession which spelled out clearly that the throne would pass from Henry to his lawful bodily heir by Queen Anne. To it was attached an oath that covered not only the succession, but everything in the act "--the annulment of the marriage with Catherine, the validity of the marriage with Anne, the rejection of the authority of the Pope in matters of marriage--everything in it."1I The oath was to be taken by the whole population. Sir Thomas More refused to take the oath and was imprisoned in the Tower of London on April 17, 1534. Reynolds gives us an insight into More's attitude toward taking the oath:

Cranmer then argued that since More had said that he did not condemn any who took the oath, he must have some doubts on the matter and, in such a case, he should obey the King as a matter of duty. This argument for a moment 
ade More hositate, but he replled, 'that in my conscienoe this was one of the cases in which I was bounden that I should not obey wy prince, sinee that, whatecever other folk thought in the mattor (whose consolence and learning I vould not condem nor take upon to fudge), yet in my conselence the truth seemed on the other alds.12

Regandless of how he felt about the divoree and the marrlape, regard-

less of his stand as loyal churchran, Sir Thomas finally made his stand on the basie of consclence. More told an Intereating atory to a group of bishops who requested him to accompany them to the coronation of Ame, and also to sccept noney to buy a crom. It exprosses well

his determination to follow consclence rather then official pressure.

My lorde, in the letters which you lately sent me, you required two thinge of mes the one whereof, sith I was so well content to grant you, the other therufore I might be the bolder to deny you. And like as the one-because I took you for no begears and myself I knew to be no rich man-I thought I might the rather fulf111, so the othor did put we In remenbrance of an enperor that had ordained In that whoscever connaltted a certain offense (whlch I now remomber not) except it wore a virgin, should suffer the palns of death. Such a reverence had he to Arginity. How so it happened that the firat ocmittor of that offense was Indeed a virgin, whereof the omperor hearing was in no small porplextity, as he that by some example faln would have had that in to have been pat in execution. Whareupen when his councll had sat long, solemily debating this oase, suddenly arose there up one of his counotl- good plain man among them-mand said, 'Why make you to muoh ado, my lords, about so omall a matter? Let her flret be deflowered and then aftor may she be devoured!'

And so, though your lordships have in the matter of the matrimony hithorto kept yourselves pure virgins, yet take good heed, my lords, that you keep your virginity atill. For some there be that by procuring your lordshipa firet at the coronation to be prosent, and next to presch for the cotting forth of It, and finelly to write books to all the vorld in defenee thereof, are desirous to deflower you, and when they have deflowered you, then will trey not fall 800 n after to devour you. Now, my lords, quoth ho, it 110th not in $n y$ power but thet thoy may devour me. But uod, buing good Lord, I w1 11 prorlde that they shall nover dor lower me 13 


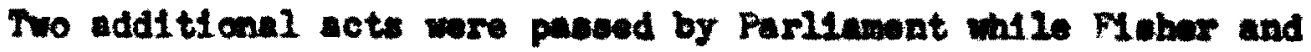
More were Iaprigoned in the Tower. The flret, the Act of Suprwacy, acknowlodged Henry to be the Supreme Head of the Churah in Ingland. The eecond ande words that epoke against the kIng's pereou or his varlous titles and cotates an set of treavon. Within the proviesone of the three aots, It wee not diffioult to draw up acoucations of treason against Fluber and Hore, even though Hore malntaloed hle elionee until arter the verdict had been brought in at tho toriel.

Various delegations Fisitad More in the rowr, attempting to get

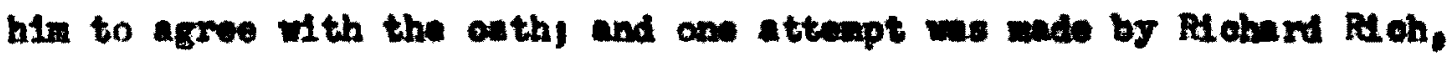
Bollottor-Oeneral, to triok him Into eaping olearly that he did not socopt the king as head of the chureh, in order that their nocueation would be lese equivoos. Ih More' a roply, which playe a key part in his trial wes as follows:

- . the caves are not olm12ar, olnce the KIng oun be made or uriede by Parliemont, to wleh every aubject being at the parliement may give hie coneant; but, we the oupromcey, the wubjoct oumot be bound, etnee he oannot give his conbent In Parliwent, and though the King be coeopted as such in Perjiament, thore ars many other oountries that do not agree. 15

The agent, S1r Thanas More, and the soene are now bafore ne in

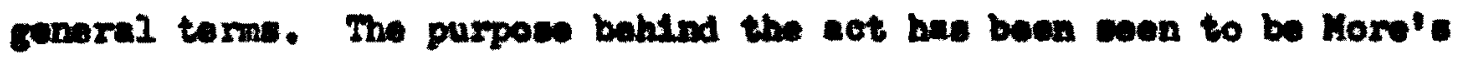
doteruination to stand on the conviations of Mle ocmelence retbor then Fleld to offlolal preseurs, even at the expenee of his 11fe. The sot 1teolf has been sketched in In broed atrokes. So gar, it hae not been

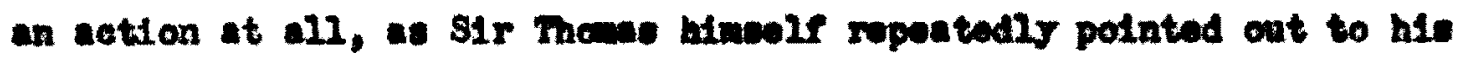
Interrogators. It was, rathor, the morusel to act.

The agoney which 1s oentral to this otudy 10 the opeoch of 81r Thomes Kore at hIs trial. We will take a eloes lock at the apoech, and 
then explore further sowe of the relationshipe anong the vartous aspecte of the total rhetorical event, lewing the naning of atrategtes as our ordtionl device.

Some textual difficulties mat be acknowledged. There is no extant record of the completo procesdings, weh wo would bo made of a modem trial. A good discuaulon of the earliest records te given by Faynolde in The Trlel of Sir Thames Move. ${ }^{16} \mathrm{cnly}$ ane of these recorde, that of Roper, wes aruilable to the writer, and he does not gatve a full accornt. Romolds quotes from several of the sources hut joes not meonstruct all of More's apech. The only complete speech arallable is found in The World'e Best Orations. "17 Tt's sources are not listad, though it obviously draws heavily frow the authentlo records named in liegrolds. All further quotations from the speech in this chapter are frow that ource unlese otherwise notad.

Hore had suffersd 111 health for soveral yearn before his imprisonment, and the monthe in the Tower had weakened hin considerably. Ho began his opeech with a reference to this oondticn, fearlng that mmory and understanding. . Should now fall we so far as to zake wo Incapable of making such ready anowere in $\mathrm{my}$ defonse $\mathrm{as}$ otherw1se I Mght heve done." He otrutogy here is two-fold: to explain hls weaknoes of physical preatence and perhape of argument, and to establish his mubleness before the King's court. This latter stratery wis typlesl of More, who was never one to appear arropant; lndeed, he often depreceted hie wry great learning and abjlity. ${ }^{13}$

Weak or not, he proceeded to rlye an orderly nccount of his Indtatment, and to answer each count in turn, is befitted a ilno lagal 
wind. He appeals f1rat to the conelstency with which he had always spcken to the $\mathrm{xing}$ on the matter of his opintion of the dirorce. He declares that maintaining his integrity by following the dictates of h1s conscience rather than basely flattering the King with dishonesty cortalnly ought not to be called treason. If his honesty can here offended the King, he considers the panishment he has already undergone ourfieiont.

His otrategy hore is an apponl to personal lntogrity. Ito effoctirenoss is based upon two conditions: his orm roputation as a man to who integrity 1s Importants and the acoptance of the basic assureption that it is more Important to follow Ood's law according to one's conscience than to follow the laws of man. The f1rat of these conditione would probably have been granted by virtally oreryone in the courtrocm. The second they may have held in principle, but were certalniy willing to abandon in pract10e. Whatover 1ts effeotireness, to More 1t was of chlof importance and, just as he zast rely on it himbelf, he must testify to it before his jurs.

The second charge was that More would not, "out of mallgmant, per11dious, obstinate, and traitorous mind, toll them [his] opinion, whether the king was aupreme head of the Church or not. . ." H1. strategy f1rst was refutation, Ito repllod that ho had always remalned silent on the matter, so that no "word or action of mine [can] be alleced, or produced, to make we culpable." More had indeed been very careful to opeak to no ono, not oren to his wife, in such way that his words could Inter bo used againat hin. What ho did answer to this question in tho Towor was "that I would think of nothing else hereafter but of tho bitter paselons of our blessed sevior and of w exit out of this miserable world." 
This 18 a winese to falth that would not sound at all out of place in Weatandnoter Hall in 1535. Broryone was part of the ohurch, and rel1glous matters and mattere of atate were always intertwined and comatines 1dentloal. A learned man would be expected to exprese himelf on relfgion as on other contemporary 1senes. More's statement would add to the Impresalon of one detormined to remaln aloos from the vexing argunent going on around hin. However, its perruanlve effect on the jurore we probably not great, for the entiment could hardly be thought Important onough to countormand the KIng' wishes.

Mors' next statesent reveals a very appealing simplloity. He said, "I wish nobody any harm, and if this does not keop me alive, I donire not to Iive." This 10 an Important affirmation about the way he I1ves, ee wil as sbout h1s attitude toward death. If the Inw of man rewands mischief between mon and puntehes Innoconce, better to die by that Inw than to live in submiesion to it. This is the strategy of declaration, by which the opeaker Intends not wo moh to persunde people to soceptanco of an 1dea, as to prosent them wth a oharacter portralt that all reanin In opdte of the dieposition of arguments. It 10, in the long run, a powerful shotorical doviee. It provides one reasen why men 14ke S1r Themas Moxe are remembered and renarated whereas thols triumphant oppononte are elther forgotten or doplored. The statoment is also a good exmole of oreative oholes of langrage, not in the distinotivenese of the words, but in the breadth of mouning encompuseed in such a short and efimle sonteace.

In the next opreral argunonte, More mingles the otrataglee of appeal to Im and appeal to conselence. He malntalne that no law oan 
puntoh a man for his silence. On the contrary, "1t is a maxim" that "he who holds his peace soems to give hla consent. . . ." Furthermore, 1t 18 "the duty of every good subjeat . . rather to obey God than man, to be more cautious to offend his consolence than of anjthing elee in the whole world." Ihe continues to bulld two cabes for his audionces one, the legality of his position, the other, the moral reotitude of his poeltion, whaterer the logal diapostition of 1t. Eech of thace ideas is algatfloant in Itself, for men mat always be concorned with both 2 w and morallty if government is to preserve 21berty. Equally as algniflount is the tension botweon the two 1dess. It 1s this tenolon which keops law from becouing tyrannose, and morallty from beconing sontimpntal. More refers to letters he wrote to John Fisher while thay were both In the Tower, In whloh, it was allogad, he had shown orldence of consplracy betimen them. Bo anye, "I do Inalet that these lottore be produoed and read in court, by which I way be elther soquitted or cosvinoed of a I1e, but beceuse you say the Blshop burnt them all, I w1ll hore tell you the whole truth of the matter." This may be labeled Imuendo, since Morv, as a good langer, would know that oridanoe wh1ch cannot be produced may rery well be non-exdetent. Who is more to be trueted," he enems to be acking, "I who wote the lottors or those who eay the letters conderm we but cannot produce them?"

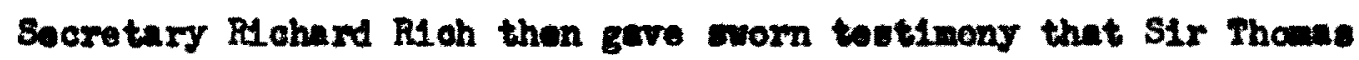
More had sald to his in the Tower that the KIng could not be the Suprome Head of the Church. We hrve already seon ${ }^{19}$ that Kore's anmwr could not be acnsidered a donial of the KIng's supremacy without greatly distorting 1t. More's roply at the trial brings out not only his eloquence, but s100, for the flret tims, h1s wrath. "If I wore a man, my lorde, that 
had no rugard to $w$ cath, I had had no occasion to be hore at the tise, as 1s well known to erorgbody, as a crivednel. . ." Thore 10 - duel strutegy here, 1rony and appeal to comon reason. How Ironie that he who refued out of honesty to take an oath should be sooubad by one tho mast take in oath dishowestly to do 1t. More gees on to an-

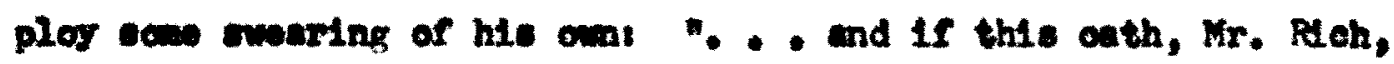
which yea have taken be trwe, then I pray I wy never woe 0od's faos, mioh, wove it otharvies, 10 an Imprecation I would not be guslty of to

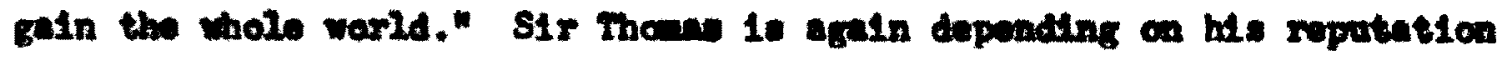

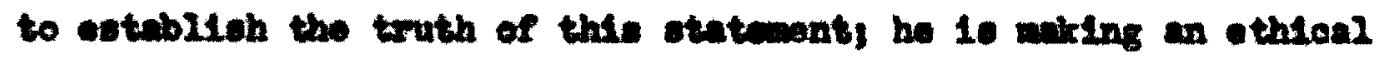
appenal. For of thesestres, the words could ourry no wolght.

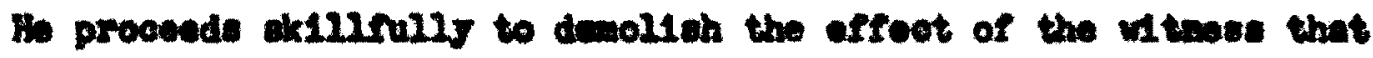

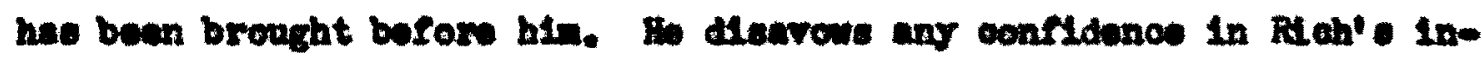

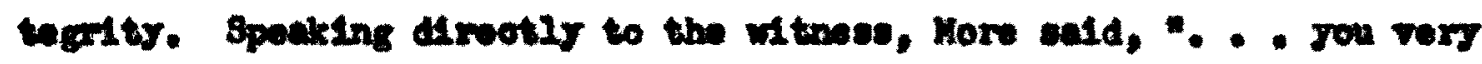

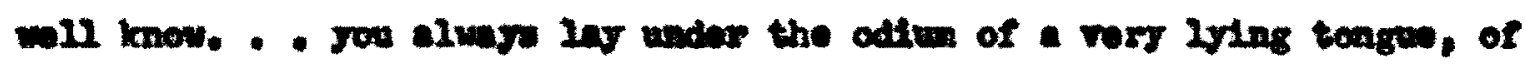
a crut gavestor, and of no goed namo and cheracter. . ." We cannot

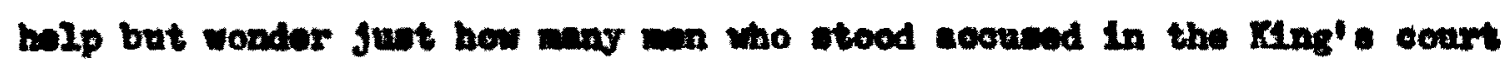
would have dared to speak so thotr acceosers in that fachlon. That Hore

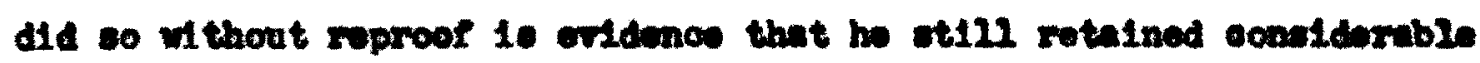

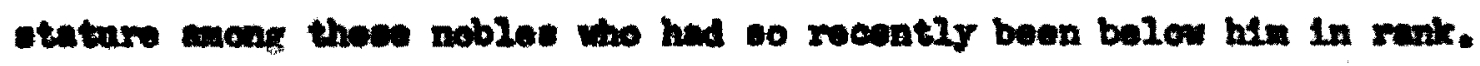

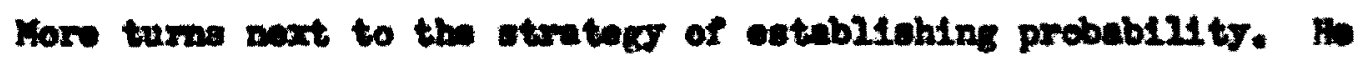
acke the court if it sosen probable that he would conflid in a porrea he esteesed so IIghtly about a matter which bo had not ontruotod to anyose eles in the world, not orron, aftor the act hed been paeced, the

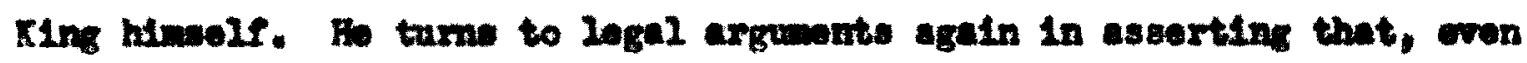
If Rlah's teotimony wore true, tho ocarerations wore laformal and no 
milce could be proved.

In a vory touching pacase, he turne to gratitude and prales to expres his rolationohip to the KIng. He talks of "the unopeakeblo

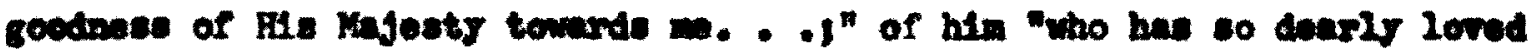

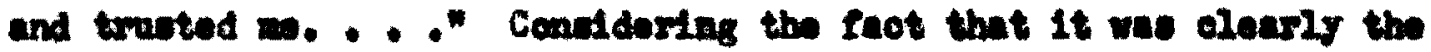

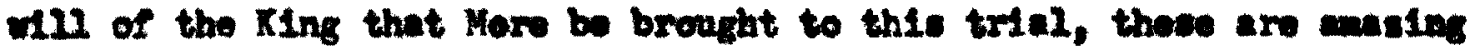

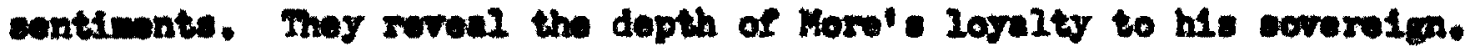
Fis personal fooling for Ranry Nudor any have aufforvd (though thare 10

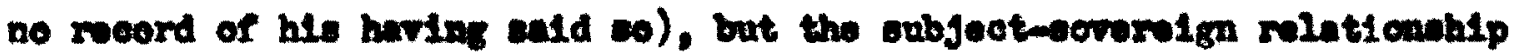
wes intect. 81r Thenav's exproselion of cratitude was part of another otrateco, howover. Ho ween probability to bring in the might of the Ring' long-tim ravor to eatablich the unlikellhood of Rloh's teatimeny haring ang anthentiol ty

-. I I eay all this, hlo Kajenty' bounty, so leng and 00 plentiruzly ocntorred upan $m$, 1o enough, in $\mathbf{w}$ opiztion, to invalldste the soandelows socusation to injurlously ouraleed and urged by this ma agalnot wo.

Hore's appoulo wore unaralling, for, as Boynolde pute 1t, "The

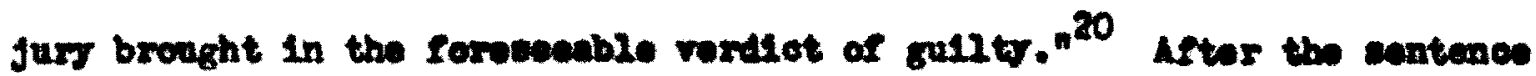
of doath was annownead, More finally apoke Erealy of hie oplnion of the Not of Sucosesion. At this point Raynold's toxt is much sullox than that

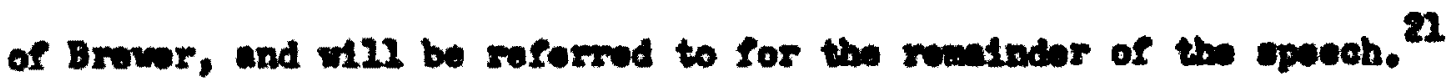
What followed was mach wore roprosentative of S1r mowas at hle best than wre the nocesearily spontanoces roplles to tho indiotenont. To puote Raynolde agetn, "The apeveh More wade we a carefully thought-out

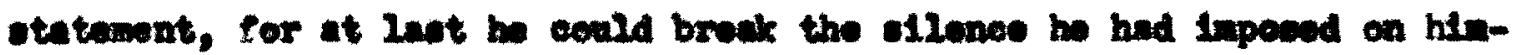
o.15. ${ }^{22}$ 
The strutogy he aploye in thene olosing paragraphs of his opeech 10 authority. He finully doclares openly h1s opposition to tha Aet of

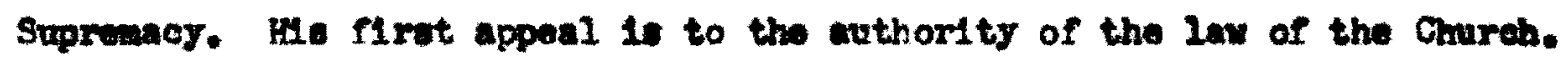

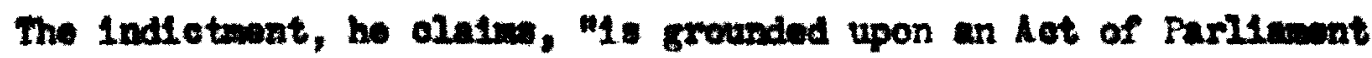
dirvetly repugnant to the Inws of God and his Boly Churah. . . 23 the showed rurther that the Aet me contrary to Englend's om etatutes, and to the RIng"s outh of orflos. The Chanoellor remerked that it was -trange that More refueed to take the outh whon "all the Biohope,

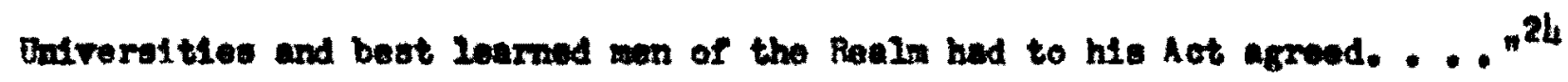
Morv' ' reply show that his great wit had not loft him, appeals to the Mder authority of andelind, and tonches upon one of the pointe that indleate how Important kore's optint on wes. We waid, wong other things,

But if the numer of Bishope and Dniveralties be so materiel a your Lordohipe wenth to teke 1t, then see I 11ttle canes, W Lord, wy that thing in $w$ oonsolenes should make any change. For I nothing doubs but that, though not in this Bealin, yot in Cnriotenden about, of thase woll-learned B1 ahope and virtuous wan that are rot aifre, thos be not the fown part thet are of ay aind therein, 25

The Impertance of Yore's opinien, to which be calle nttention bare, aunot bolp but ongege our attention. It appears that Henry could not

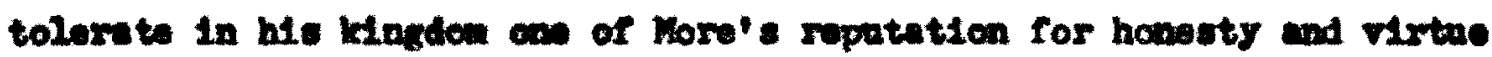
who did not cupport his sotions. It was not so moh unanimity the king was soekling as S1r thomen Morv' approvel, or his remorel.

More elosed his opeoch wIth the wish that he and his judges wght

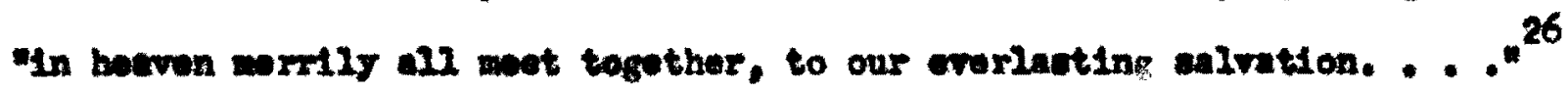
Ho wa able to aceopt his ismoltable fate in the context of h1s fatth that the Ilfe be was galning wes nore 1mportant than the one be wo loning. In a olmilar viln, be could lock with calmoses upon those who 
contunoad hin, bolloring that g gater Judge then any of thom had the 42 Inal eny. Hia behwior at this point dres addod point to a polgant otory told by Roper. He is denoribing Hore' Iast doparture from he how bafor his impriaowont.

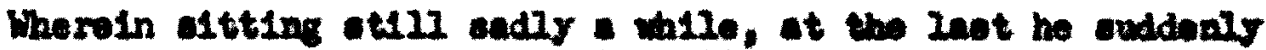

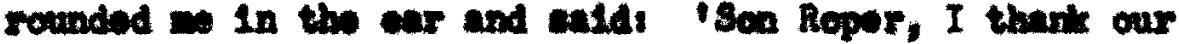
Lord the fleld is won.' hat ho mant thoroby I thon wit

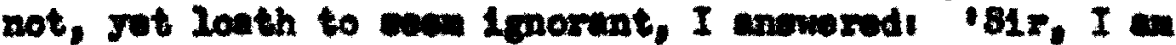

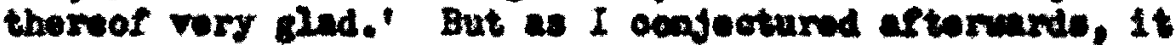
wa for thet the lowe he hed to Bod wrought in hto as

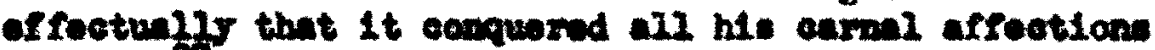
utter. 27

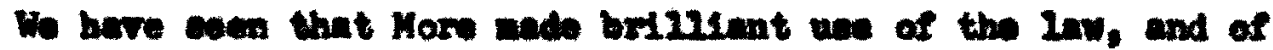

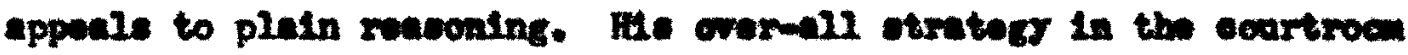

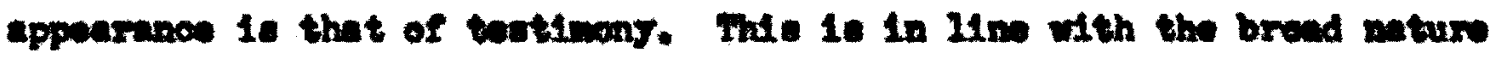

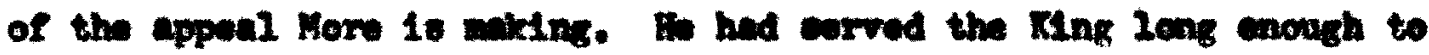

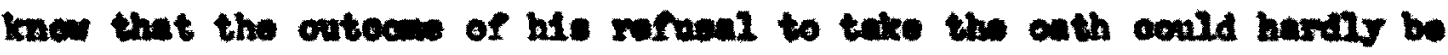

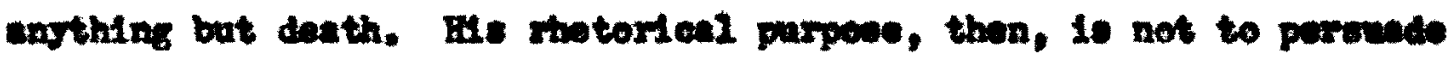
the jury. though bo and 14 es defloult for the so bring in " "gallty"

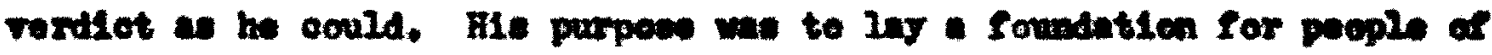

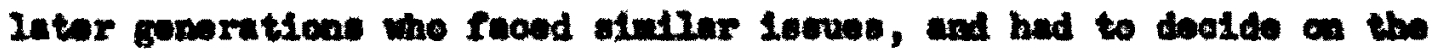

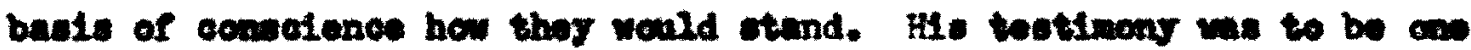

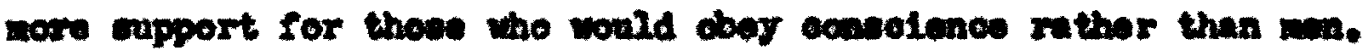

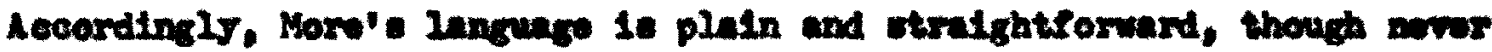

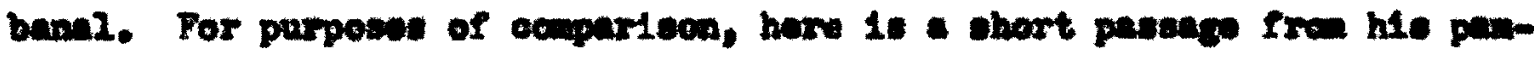

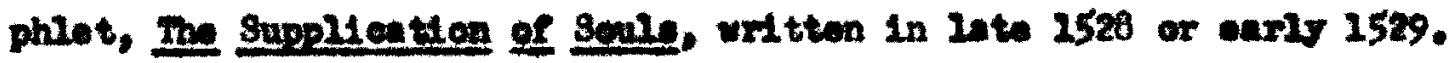

The couls apaking hore are gpecking fron purgator.

If any point of your ald frove, any picoe of rour ald

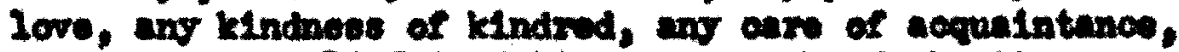

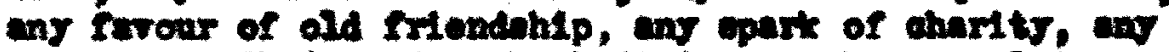
nupeot of Chriatenden, be ieft in your beares. Iet nwex

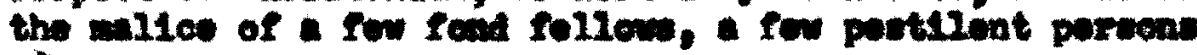


borne towards prienthood, meledon, and your Chrietten fath, res out of your boerte the onre of roar kindred, all foree of your old Irlands, and all ramabrunce of

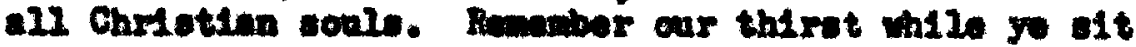
and drink, our hunger wh1le you be feactingl war zost-

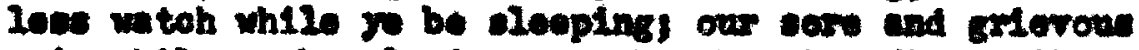
pein while ye be playings our bot byrntng Are while $p$ be in pleacrer and eporting. - . 88

Hare the Inguage and the agntax are nore polishod. Tho ropotiten of

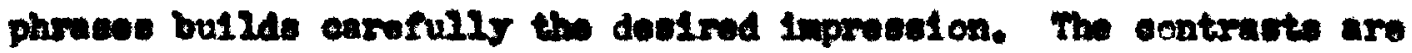

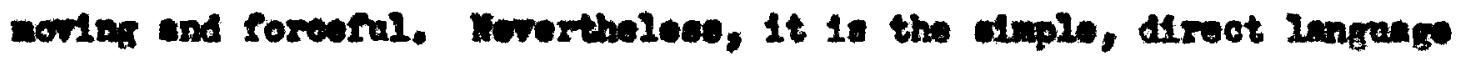

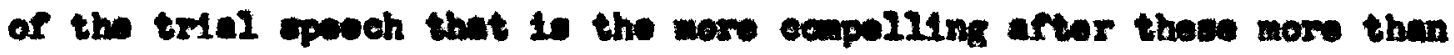

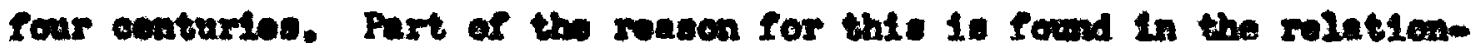

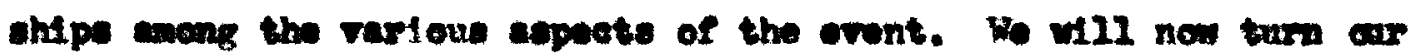

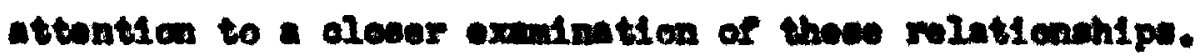

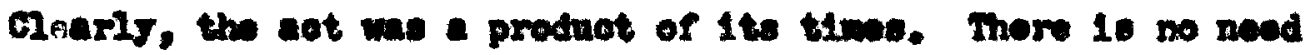

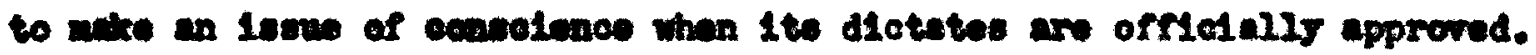
But when offietal polloy forbid the aet that a min's oanouienoe wourd

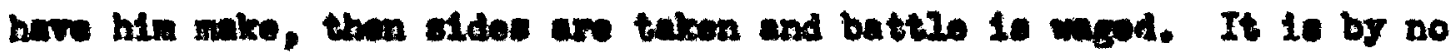

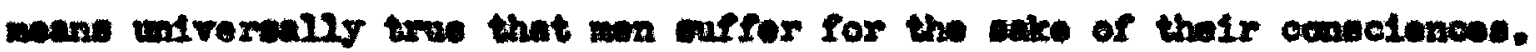

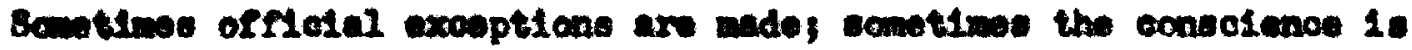

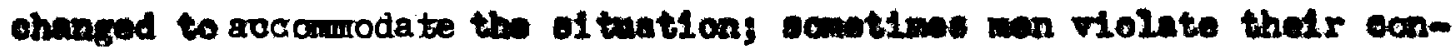

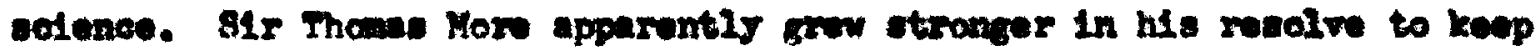

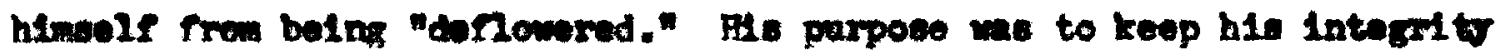

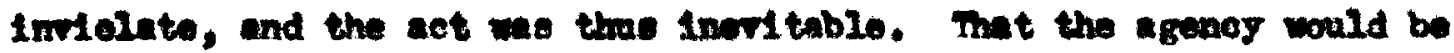

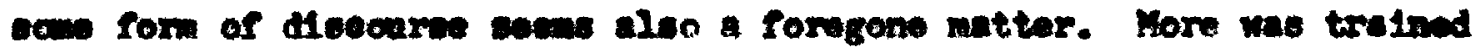
in the use of worda, both in witing and epolking. Ho was a proninont probl10 I1gure, and a notbble rotponse would be expeoted of hin at hio trial. It we, In faot, BIr Theme tho nade the triel a notable ovat.

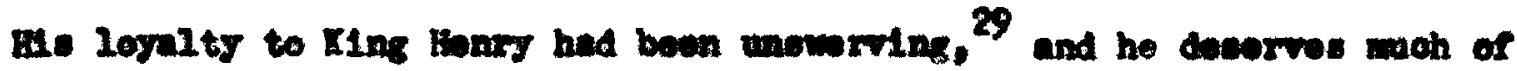


the oradit for the enooth adniniatration of fustice and the statemanlike qualities of the earlier part of Henry's relgn. In another age, wth another monarch, More might have been able to make hls stand with Impantty; but Henry was driven by an assortment of strong passions that he could not or would not check. So, one of the nobleat men of his realm foll.

In following hts consclence and heading for falrly certatn personal dianater, More did the best he could to leave a legacy of honasty to hls auccessors in the etruggles for freedan. The means he took to do so wre about the only ones open to him. Had he spoken out soonor agalnst the KIng' matter, his cbedience to the KIng would have boen aullied and hio beet legal argment deatrojed. His ollenes, followed, after his comliotion, by his clear demunciation of the Act of Supromoy, was appropriate to his purpose. HL purpose was sharpened as the ecens about hts beoune more and nore one of accomodation to the KIng's wisbes, regardless of the ahuges of mind and govermment it entalled.

The "man for all seasons" Itred and died the KIng's good eerrant, "but Ood's first." 30 In his spexking and in his actions, he provides an exmale of powerful rhetorio. Its effectiveness must be judged on the basis of 1 to inhoront worth and More's ultimate purpose for it. We have seen that that purpose was to add oupport for the primacy of comclence orer law when those two conflict. By hls otrategles of testimony and his appenl to the law he succeeded in giving that aupport In a very oubotantial way to any who wish to appropriato 1t. Its inheront worth has been spulled out in choice of langunge, signifleant Idoas, the orodiblitty and integrity of the spouker and h1s measge. 
That h1s rhetorfe did not win his relesse is the ocnaequence of the scone in which he Iired and apoke. As Reynolds says of the Jury,

They muat have been overmawed by a Comisation that ineluded the Chancellor, the two Chi of Justices, the Chlef Baron and other Judges, together with Anne Bolern's father, hor uncle and her brother, the KIng's brother-1nlaw, and, not least, Thomas Cramiell. It would have been out-of -keeping with the ties for the fury to have brought in a verdigt of lot Ouilty. Thomes More did not expeot equittel. 31 
1. Judge Jahn O' Hagen, Introduction to S1r Thanas Hore, Utopla and D1alogue of Cofort (Londont J. M. Dent \& Sons, Ltd. 1910), Pp. $\operatorname{xod} \bar{\nabla}-\nabla$

2. Quoted in R. W. Chubere Thomag More (Ann Arbor Paperbacke: The Univereity of Miohtgan Preas, 2956), p. 177.

3. The date 1 unoertain. 8ee E. E. Reynolds, The Fleld Is Wea (Mlwakle: Brice Publiahing Co., 1968), appondix I, $p, 383$.

4. Ib1d., p. 4.

5. To1d., p. 33 .

6. Iold., p. 76 .

7. Iold.

8. W11Lan Roper, The LIfo of S1r Thomas Hore, in Richard 8. Sylveoter and Davis P. Herding, eds., Two Early Tador Lives (Now Heven: Yale Untreratty Preas, 1962), p. 200.

9. Tb1d., P. 202.

10. See Reyrolds, op. alt., p. 253 for a discussion of More' reasons for restgaing.

11. Reynolds, op. e1t.. p. 298.

12. Ibsd., p. 303 .

13. Roper, op. c1t., pp. 229-30.

14. Reynolds, op. e1t., p. 341.

15. E. E. Raynolds, The Trlal of S1r Thones Hoxe (New York: P. J. Komody \& Sons, 1964), p. 69.

26. Ibid., chs. 1 and 2 .

17. David J. Brwwer, ad. The Worlds Best Oretions (St. Louta: Ferd P. Katser, 1900), vol. v111, pp. 362-367.

18. Seo Reynolds, The F1eld 1s Kon, Pp. 118 and 237. 
19. Soe above, p. 6.

20. Roymolde, The Held 10 Wan, p. 366.

22. Rngrolds, The THal of sir momas More, pp. $120 \mathrm{rt}$.

22 . Io1d., p. 120.

23. Fold., p. 121.

24. Irold.

25. Iotd., p. 124 .

26. To1d., p. 132.

27. Roper, ge. at., p. 238.

28. Paymolde, Ime Pleld 1s Won, p. 215.

29. Rayolde, Im Irtel of 81r Thanas Yore, p. 242.

30. Ibdd., p. 151.

31. Ibld., pp. 218-19. 
CAAPTER IV

A WAH FOR ALI SEABOMS

The Ilfe of Sir Thoma More sas a dramatic on. It had the - leaventa of wit, suppense, Intrigue, strong aharacter, and groutnose that acmiblne to wake axoltin and worlng drans. In the contaxt of bie t1mas, his etand provided the rivid ocntrasts so mocesenry to good thentre. The events of thow times were paceant-11ke in ecope; overwheluting peesions could eacily be gratifled, espocielly by the ereats the extromes of mann behwior were seldom modernted by the touches of

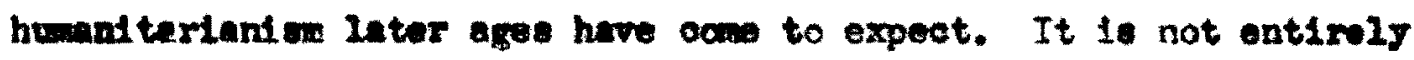
colncidental that this was the ape that would shortly produce Chriatopher Marlow and WIL1 in Shakeopone.

More was intervoted in dram, both sa entertainnent and as a tenohing tool. Hogrefe tel2s ws,

The reord of dxame in the Hore alrale begen in the hounhold of John Morton, A rohblahop, Chancellor, and later Cardinal Morton. There Henzy Hedinll 11 red frem 2490 to 1500, and there his Hature and Tulgens and Lucres ware probably perforwed. There Korv, as a boy, Dout 2490 to 1L92, used to oteo in anome the players and dellght Horton and othere with his extempere opeeches, and there, partiap, More wrote playe and acted in the 21 ttie comedies which Branue wontioned. 1

This was, of course, a onildhood intereet. But it ceons to have onrricd orer Into maturity. Hogrefa goes on to oay.

Hore perhape anried on his drantio intervets in other places. In his letter of 1501 to john Holt, he spoke of - conedy anlied Salomen. which 'w' wrote, probubly to help teach boys thalr Iatin. Probably More kept up his 
connoctions with Lincoln' Im, sinos it was abul for gentlemen to do vol he wy have been the poreen meant in an 1tem of $1529-29 \mathrm{i}$ 'Master of the Rorelst Arnold. If not, More. 1 ?

Hegrafe damonstretes that Hore and the other acholare with whom he wa clowly assocleted presented many of thair leading 1deas in drametio fonw. They recognised in the thatre powerful tool for maklng thatr ideas accoptable and attractive.

It was alnoet inovitable that More vould himealf becme the oubject of dramatic portaral. One of the earilest of such portreyrals wa a play entitled S1r Thoes More. Its dete and anthorwhip aro obscure. The manuscrlpt, which soems to be orfolnal, berare the hand writing of soveral different writere. One of thooe was arter of marked exonience, and 19 thought by sow, though not $a 11$, to have been $4111 \mathrm{xm}$ Shakempare. 3 arege assipne $1 t$ to a falriy early date, probably around 1592 or 1593.4 a large portion of It deale with two events: the riot in the City of Landon in which More played a mjor pacifying roles ${ }^{5}$ and Herv'" Inprisament and exuoution. In this play, More's oonsolence is - contral thowe. In one epeech he aevs

No Mr. Leutennt, I thanke wy Ood, I have peace of conesience, though the world and I, are at 11ttle oder But wele be owen now I hope, exe lon: when 1s the exwoution of your warmat?

A modern play in which Moro $1 \mathrm{~s}$ the main cheracter 1.8 Ion For 111 Seasons, wrtten by Bobert Rolt and flrot prosented in New York c1ty on November 22, 1961. The play nes well recelred by both publie and critics, and will serve pory wil as a tool for the impestigation of how falthfully drama can recreate the rhetoric of historical flgarea. when we begin to apply the dramatistic pented to a play, we 


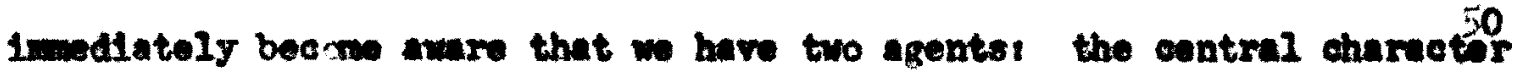
and the playurdght. Conequently, we have two cots: More's refusal and Bolt'o statement; two egenoles: the opeech and the play, two sceres, one hietorioal, the other theatrioal, and two purpowest More's dealro to stand on consetence, and whaterer oan be discorered or oumieed to be Bolt's purpose in writing the play. The first wet of elenente we have dealt with already a w found them in the date derived from tho tudy of More. Now, they mut be convidered as they are found on the pages of the play. The second cet, those that derive oolely from Bolt, must also be exawined to weo how they reinforos or nodify the rbetorlal force of fore hineelf. It Io scinawledged that the line between thees two sote is often hard to dotingulah, and that thalr relatire inportunce varies same from one relationship to another.

Ve herin with the pley and the playmight. Fe can gain valuable Inalght into the play as wole if look first at Mr. Bolt's parpose in writing 1t. In en intervew, Bolt eald, It is play about the self. We are losing the 1 dea of what a self 1s. We Inck courugemmental oourage. It secaned to ne More had 18, and thet' why I wrote about hin." ? He elaborates this in tbe proface to the playi

At any te, Thones More, as $Y$ wrote about him, becane for

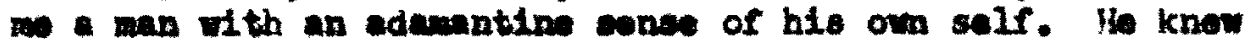
whare he began and left off, wht aree of himealf he could yield to the enoroachments of his enemies, and what to the encroachwents of those he lered. It wa a mbetential aree In both osses, for he had proper senee of fear and was a buay lover. Stace he was alever man and areat lawyer ho was able to retire irou thoee araes in wonderfally good order, bet at length he was aked to ratroet. frow thet final aroa where he locuted his self. And there thi supple, humorous,

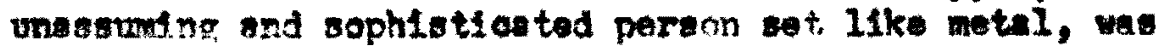
crertaken by an abolutely primiture Hgor, and covld no nore be budeed than eliff. 
Apparently Bolt wanted to get an Idea scrosas to Influence people-mor at least to present an infuential idea in the theatre. He sees a oocinl need and helieves that More's ilfe can contribute signifleant 1dee that will holp to moet that need. The need, he describes in tormo of mptiness: "5oth soolally and Individually it is with us as it is wth our elt1es--an eccelerating flight to the periphory, leaving a center which 1s expty when the hours of busineas are over." 9 H1s purpose, in other words, was rhotortioal.

Waltor Korr gived a Ilghtly different perapective on Bolt's purpose, though the focus rematins the eame. He sayo:

Por it is dramatiet Robert Bolt' moet Nigoreus intention to put the cownon man back into his very camon place and, by oentering our attention upgn a experb wind in reotion, to restore wit to the world. 10

By wt, Terr ans percoption, powore of Intellootnal procision, senee of values. If Robert Bolt wane for his play to reatore this to the world, he surely has a rhetorlcal puspose, and one that concentratos on the wif through the modium of a wan whose consclence bade his preserve h1s self at all coots.

Bolt's act, then, is his statemont of this important truth. The agenoy by which he makes his atatement is a play. Fhetoric is no stranger to drama. Indeed, one vritar says,".. thetorice can be rogerded as an esential ingredient of theatre. As long as pley offers a histrionfe view of chareoter and situation, rhotoric is its natural conconstant and moans of expresaion."11 A play has soveral adrantages to offer for the prosentution of material of rhetorical inport. It can not only be read, 1t can also be produced anis moen. It will be rend and seen by peoplo otber than just those who are interested 
In its theme, whioh is not slways true of an eseay or a book. 81no the theatre is seen by most people as an entertaiment medium, 1 to weseages rench many people whe expect to be entertainnd, sut may be moved or

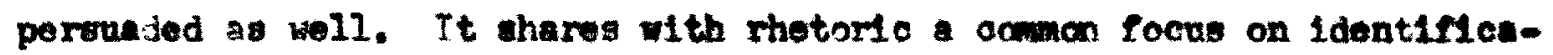
tion.

In one sonse, the scene of the playwright's oot, io the theatroany particular theatre in which the play may be produced. This means that the act 1s repented over and orer agin. When play 16 as sucseseful and popular as 1 Man for 111 Seesons, it may woll be repeated for ecreral decedess even several conturles. Consider shakespoervi In this sense, the ecene heips to shape the ect by providing an Interchange between one partloular eet of people-me cast, and enother particular eet of peoplethe audience. Fivery sudience is different, so every performance is different. The acoutics of the auditorium, the af of the stage, the temperature inside and outalde the building, oren wht else is going on In town that nipht will all affoct the performances and, coneaquently, they w1I affect 1 ts motomoul qualltea.

In another sense, the ecene is the oconsry-the stage eatting for a particular performance, represeating the phyalcel surroundinge of th which Thomas More was Pamliar in Slxteenth Century England. Bolt Intonded that his play should use "overtly theatrical mans of suttehing from one locale to another." 12 This means that the curtalns are not ued to Indionte change of ecene, except at intermisalon. Ine set is ueed throughout the produotion, with change of ocone Indicated by changes in the 11ghting. Kex'r said nt the Broadway production, "The pling locked as 1t reads: enare, pointed, pieralng. 13 
The author Intended thet the scane heve a maphorical mereronos. Ev says,

As a fleurs for the axparhuma context I took the Inreet. most alien, leath fonminted thing I know, the son and wher. The roforonow to ohipe, rivers, currunte, tides, nurigation, and wo on, are all wavd for thie parpowe. Society be contrat figures es dry ind. Ili

The capertwonan context, for the dureter, is the divin, everwarohing Churoh. Bolt takes that es a wetaphor which be expresese in the f1gure wer. Some of the opeeches and extene way be elearer wen this reletounip is kept in wind.

The agut ("Robert Balt, 37 rowre old, of ptocky bulld, author of

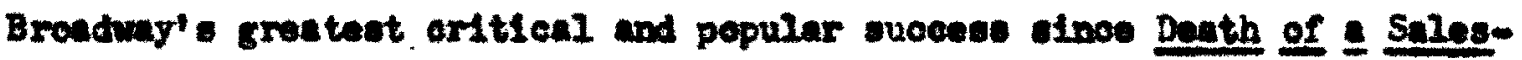

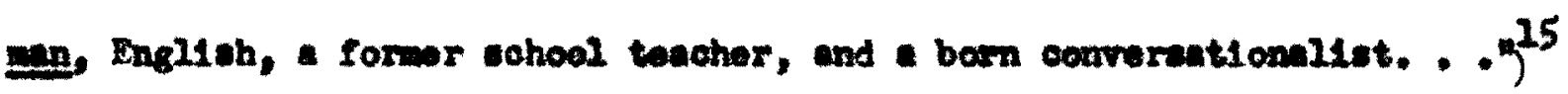
1. bet diacoversed, for our purpowes, through a atudy of his play. Whether or not be falthruly preserres the rhotorle of his contral aherneter w11l determine how effoctive he 10 in this rhetorleal orent. In this onse, the agont 18 enboldiary to the ageney.

We turn now to eame of the etrategles und by the playmight as

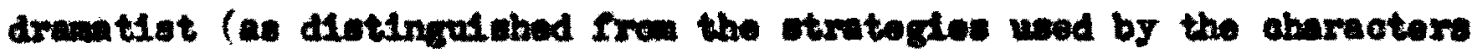

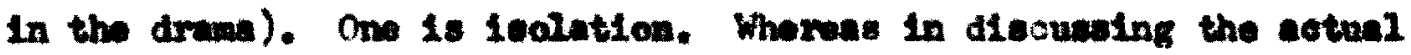
orente one wast be anere of a2l the forses that are at work in a part1oular estuation, in play the writer on, when he whed, fowe upen only those foroes thet add to the point he 1 trying to make, loaving otherv only dimly prosent or ocmpletely 1enored. For example, Cardinal

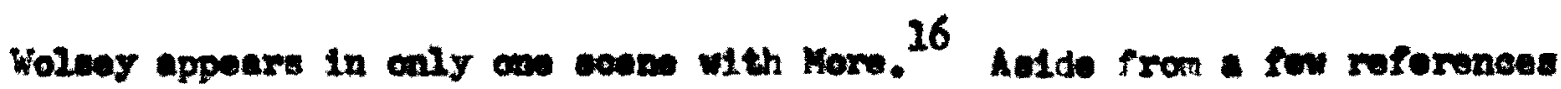

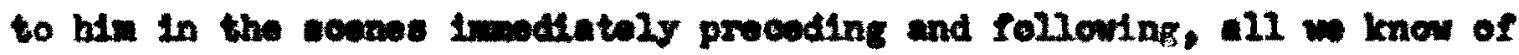
tho Cardinal is wat we lourn in this soone. We aro told nothing of the 
Cardinal's ambitions to be Pope, of his arartce or his mandpulation of Churah property to hIs oun adventage. But in the brief Hew wo are allowed, the playwright manages to create a ploture of a corrupt church and an infinf tely accommodating ordinal. contrasted with the integrity and vuavity of S1F Thowas Yore.

Another, simflar strategy is that of giving More added prominence and King Henry less. Iren More's blographers can hardly aroid making the Xing seem more Important than More good deal of the time. While hle presence is felt constantly, Henry appears in only one soene. 17 His somowhat whinsteal nature and his intense deteraination to have his om way are established in that scene, so that hls extreme displeasure and final rejection of More later are underetandable. It is olearly More's show. It is his characterisation that is carefully bullt up before us; the others serve malniy to highllght him. This can be called the otrategy of emphasis.

A atrategy thet follows this is contrast. More' a ateadfastness 18 seen againet the opportunism of Crowell and pich, the deprarity of Wolsey, the adsptability of Norfolk. Granted, the contrasts were there In real Iffe, but the playwright arranges scenes and dialogues so that the contrasts are compressed into vivid and memorabie opisodes.

An inportant strategy is embodiod in the character of the Comon Man. Sametimes he turns from the action to address the audience directly. At other times he takes various utllitarian parte, mostly of servants (though also of the executioner). Hers says of him:

The ccmon man, of our own and every century, is kept In view $b_{y}$ meane of a knowing, impudent, hardheaded otage manager tho havis frosh costiunes out of the hamper of time, thips the fumlture about with slapdash 
ofmolency, playe any onall role thet requires no ha1roplitting, and in gonomal gete through the world with wink, ticklo, and a areve. The phtlosophtsing of atricter, more stuisborn men is not for him; he is phllosophical sbout all thit, trusting only such gritu$1810 s$ as he can hold in his hand. When he turns to the audience and offors us the plous hope that we w11 all dio in our beds, he ia ineulting us and he knowg it. It is men of ocompromdas who die in their beda. 18

Thla vtratepy has en important thatorionl function, for it tends to draw the audience into the action of the drama, thus exposing them eren more fally to its perowasive elements. Fven if the viourar falls to Identify with the common man, he is led to take a sharper look st what 18 rolnt on when he is addmssed directly. Th1s strategy may be called alienstion, if we underatand by that, not hostility, but what Bertold Breoht has deccribed a: "a teohntgue which confers on the human erente to bo prosented the staup of the conspicuove, of something requiring an explenatton, something not obvious, not simply natural."1S 3olt made 1t clear that this wes what be had in aind whan he told Dr. Driver: "In 1 Man for 121 Seagejas I nood Brechtian techniques. Thay broice up the narrative and allowd wo to expand the play, so that ite ocmunt becoses very broad." 20 By allowing the Camion kan to introduos location and stuntions, thim atrategy also smplifles the stage acting and mikes 1t posiblo for the entire protuction to highlight the characterizetion of Morr.

Ye have seen how the playmipht ues the strategles of ha art to brtne into sham focus the plotnre of $51 \mathrm{r}$ Thomas More as a man of consolenoe and Intermty, IIfing by the Iav, but willing to die when obeylng the Ink unult betray his cansclenoe. We will now turn to an analyelo of Sir Thrans For as oharecter in the play. 
The firet thing to obeorre is that ect, agent, agency, soene and purpose remain muoh the eame in the play as in history. Bolt has taken scme liberties with history in order to keep the atory and the size of the chst manageatile for theatrical porposes. For example, it was not Norfolk but Audley who presided at More's trial and pronounced the sentence.? However, he has adhered very closely to the main points of the historical story. Thus, the act remains More's refusel to take the anth to the Act of Supremay and his otands related to his refusal, the agent is More; the egenoy is More's speaking the scene lis Bixtenth Century England and, epeakling genereliy, the Sourt of Panry VII; the purpose is More's determination to keep his canecience inflolate. Ine inportant modification onncerns the agency. Whereas in narrative nccounts of the evonts wostly excerpts from letters, books and opeeches, with only a few brtef renorts of converetions, in the play we are almoet entirely IImited to oonveration. Thus, the trial speoch which was the chlef agency in Chaptar Two, is represented by only three or four short opeeches in the play. The agency, in the play, is any speech of More' that bears upon hit concept of conwelence. W will now look at the strategies eraployed in that agency.

In the first scene, Fore is discussing positions with Rlohard Fleh. "A man should go where he won't be tempted, ${ }^{22}$ he tells xich. ill strategy is warning. He has reasan to belleve lich needs the warning for hisceif, tut he 180 makes it one of his own principles. An he tello atch, "Richerd, I was combanded Into offlce; it was inflicted on me. ." We are rery quilo?y moved fnto the heart of the confliot over the dealred divorce of Gueen atherine in acene between More and Cardinal Wolsey. The Cardinel says, "Ycu're constent rogret to mo, Mowas. 
If you coul? just see facts lat on, without that horrible moral squint; with fust a little common sense, you could have been a statesman. 24 The strategy is disparagement, and it works in two directions. It shows the Cardinal's compromistne nature, anj it helps to establish rore as one who will not compromise at certain important points. So far in the play, those points have not been clearly set forth. There are indioatfons later that Yore 13 willing to go along with the Intrigues of state within the limits that he nust set for himself. He nover would have become tord Chancellor, for instance, if he had not had considerable willingness to adapt to the deviating necessities of the KIng's varlous enterprises. At this point, wo know that Nore's "moral squint" definitely effects the ray he loniks at the matter of the divorce.

But More is not concerned only with keeping his conscience intact. He is convinced that there is a larger issue involved. A few lines later he answers question from the Gardinal by saying, milell . . . I belleve, when statesmen forsake their own private conselence for the sake of their public dutfes . . they lead their country by a short route to chaos. ${ }^{25}$ Here the strategy of testimony is employed to put a personal belfef in a larger context. Th1s speech shows several of the character1stics of good speaking nared earlier. ${ }^{26}$ Greative cholce of language is shom in the contrast between "private consclence" and "public duties." It catches the attention and puts two large and important concepts into Juxtaposition in a way that makes the relationshtp between them natural and manageable. Both phrages refer to signiflcant ideas and the tension between them is one that has always been crucial to the process of government. "They lead their country by a short route to chaos," is vivid and direct, emphasising with short, strong words the Idea being expressed. 
The next several scenes serve to show the warn, happy relotfonship within the vore family circle; and the intrigue that is bullding up around Cromell, Pich and Chapups, the Spanish Ambassador. We then see the ring in visit to the Yore home at Chelsea. In the midst of some general sociallzing, the KIng asks Sir thomas if he seas his way cloar to support the King In the matter of his divoree. Yore replifs, "Nh, alas. As $I$ think of it I see so clearly that i aan not cane with Your Grace, that my endeavor is not to think of it at all."27 His strategy is testimony to his convictions, and to his anguish at having to take the stand he does.

Henry gives a very eloquent tribute to More when the latter asks him why heede his poor support is everyone alse sees the polnt. The ring says,

iecause you are honest. What's more to the purpose, you're known to be honest. . There are those like Vorfolk who follow because I wear the crown, and there are those like Master Cromell who follow ine because they are jackals with sherp toeth and I am their lion, and there is a mass that follows me because It follows anything that moves-and there is you. ${ }^{2}$

Nore replies, "I an s1ck to think how much I must displease Iour crace." ${ }^{29}$ Henr's stratigy is tribute for the purpose of persuading; More's is apolog; but nost inportant at this point is the playwright's otratogy, wifch 18 to hotghten "inre's attributes of integrity and conscientiousnees.

Tn trytho to justify his stand to his angry wife, ifore refers to the linit of his adaptab1lity. He tells her, But there's a little... Iftile, area. . where $t$ must mile myself." 30 in defen of that "Itttile area," tom is willing to give his life. 
More pate himeelf on the side of the $20 \mathrm{w}$ and expreseas his conftdonee In 1to protection in apeoch to his fandig. His devghtar, Margaret, hae acked if be can't be plain with them. His enomer 10, "I atand on the wrong alde of no statute, and no ocmen law. I have not disobegod uy sorerelen. I truly belleve no wan in tagland is oafor than mreele. And I want ay mpper. ${ }^{31}$ He perolote in thise ollonee in the

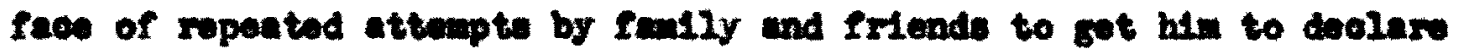
h1mee2f. Ha vas consldeat that his sllenoe would be hil logal refuge. But the Inw an be manpaleted, and otbore did not look kIndly upen his

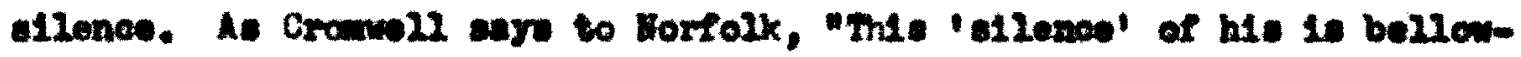
Ing up and dom Europe In $^{32}$

In rapid eequence, England's tien with the Pope wore covered, Bir

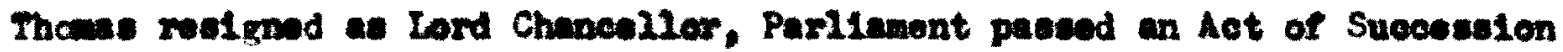

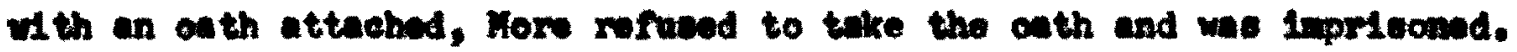
Al. otend remalnod eonotants be appoeled to the Inw and his coveolenoe. When Norfolk asked, "Can't you do what I did, and ocme with es, for fellowatip?" More replled, "And when we otand before Ood, and you aro

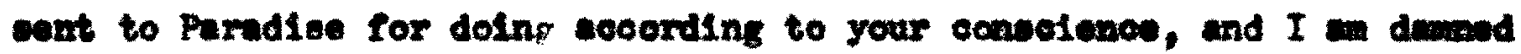
for not dolng according to mine, will you cem with mo, for fellowehtp? $3 / 3$ The otrategy is pertly teatimony to the ultimate importance, in More' aind, of consulenos. It is aleo alever way of polnting up the oontrast botwen More's sorfousness bout the Inove and Marfolk' cester adaptab121ty.

In another use of the etratery of tentimony, More elucldates the notmecons rolationship. Ho mye to Margaret,

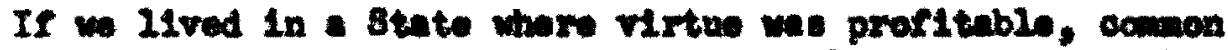
cones would anke ns good, and greed would moke us salntly. And w'd live like antanis or angole in the happs 2 and 
that need no heroes. But sines in fact wo what ararlee, anger, emy, pride, eloth, Inot and ctupldity cemenly proflt far beyond hw121ty, ohatity, fortltude, justion and thought, and herve to choose, to be hwan at all. . why then porhepe is augt stand fart a Ilttlemeven at the Hid of being harees.34

In another t1w or another place Mord's act wght not be neceasury or

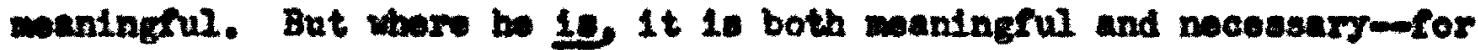
hin.

It his triel, More continues his rafueal to opouk out on the mattor of the diroros, wlintaining that "the worid mat congtrw acoording to

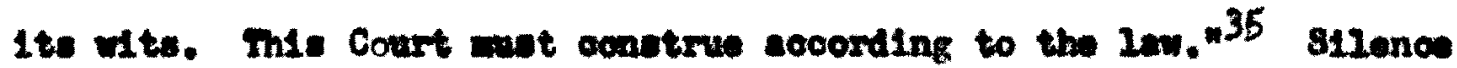
eannot be conetruad to be daniel. Iot, oren if the In be turned aglnet hin, "In miters of oonectence, the lojel oubjeot 10 mere bonmden to be

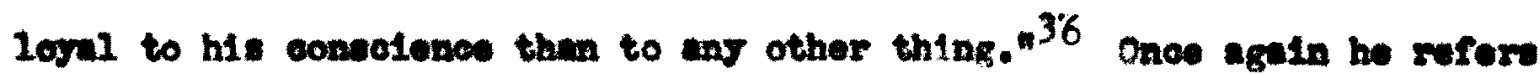

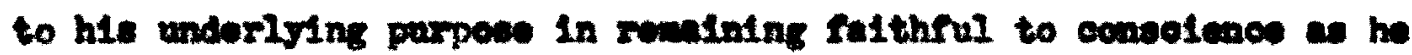

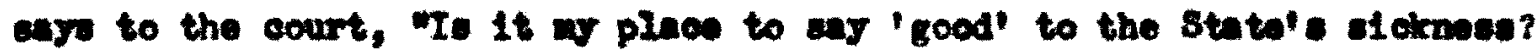
Can I heip ny king by ctring hin 210 wan be ede for trath? 1112 you help Bngland by populating hor with 21are?" The etrategy of 1ray is hexe exployed to axpese the ohnllownes of the position of Hore'

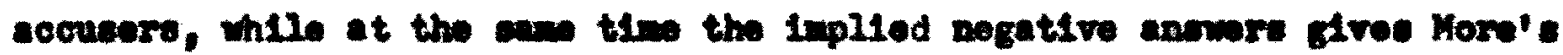
retionsle for romining otsadrant.

After he be been pronotuced gullty, Kore flnaly epeake ble and.

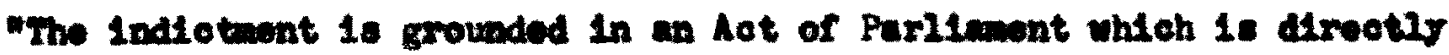
Iepugant to the Inw of Ood. The KIng in Ferlienat camot bastew the

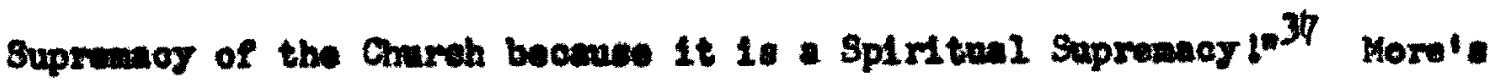
Pinel etrategy is demuncietion. Now there on be no question about ware he otands, and why. If that be traneon, then Horo 18 roelgeed to betrayed. 
With the analysis of the play before us, wo now procend to exmatine the rhetoricel atrategles we have found, and discuss whethor or not thoy are falthrul to More' on shotoris.

It should be soknouladged that a good doal of Information about the provistane to which More objeoted has been oultted for the reke of

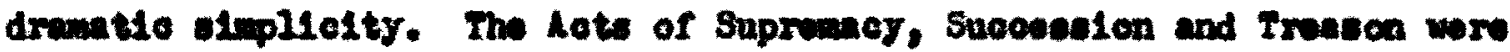
.11 Involved, and thair Inplleaticn were far-roakhing. There wro wany forces on both Wore and the Iing that are not sontloned in the play. Iot the shotorioel fores is not 2oseenod thereby, and way oren be inorvaned. S1r Themal More cuerges as a man of tremendowe courage and lofty conviotion, atanding againat a forddable dieping of thesr foroe that macked ab abreal morel vaclilation,

The overwall atrategy by which this pletare of More is achlored 10 teatimong. Ropontediy, ho toutifles to his completions and his falth

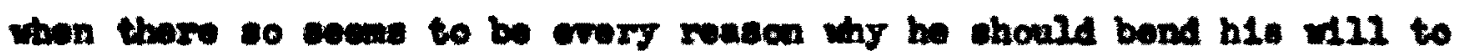
that of the KIng. Testimony 10 a whese to what on believes to be

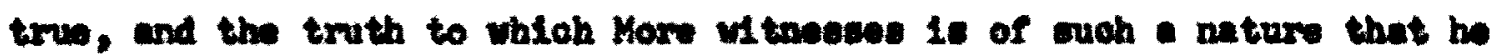

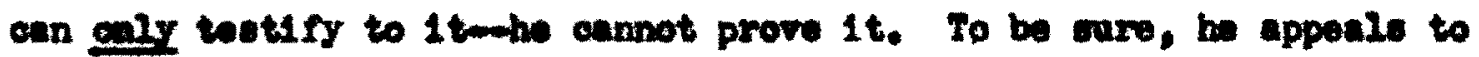

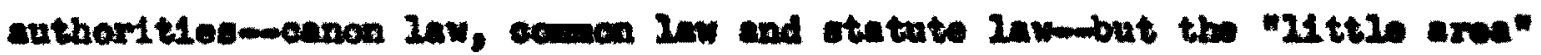

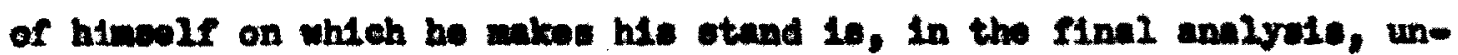

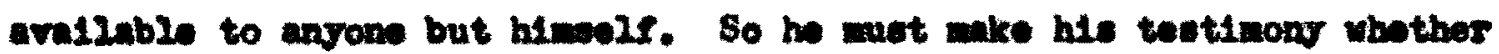
or not 1t earns hil a ventiot of innocent.

His seocadary orerwall otrategy is 2ogallty. Ho makes witty and sophlationted wee of the 2n. Bo knowe 1 te wall, has dieponeed 1t, argued by 1t and lirod by 1t, and now be expeots it to sheltar hin. That it did not 10 no diserndit to the 2aw, but to thoes who manipulate it for ond that are inindoel to $1 t$. 
How effoetive wro his etrategles? In terwe of unning Nor hts Iroedon, of courve they falled. However, there is 11ttle the plarmaght an do about that! Ho is not at 21 berty to reant hietory to moh degree. But in hrve seen ${ }^{38}$ that Bolt wrote the ply to present a plom ture of a mon who had the natal courage to be true to his aelf. For that purpose the etreteglea ere affective. The ploture is clear and

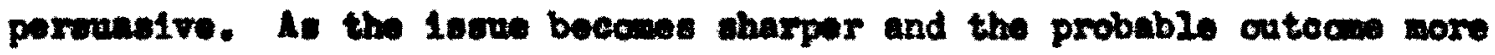
apparent, Hore derines the territory he 18 umilling to glve up, and

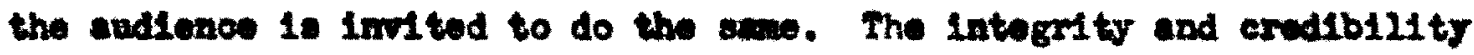

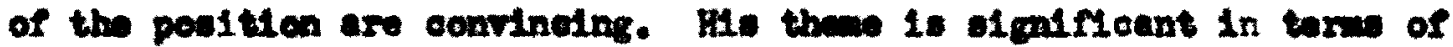

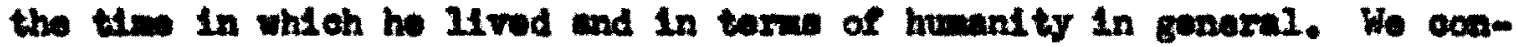
elude, then, that his rhetorian otrategles wro effeotive.

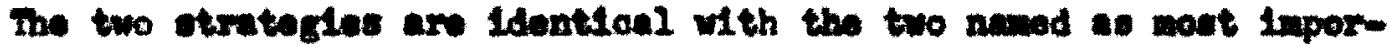
tant to the hietorioal Thowa Nore. In the play, they are put into now couverastionil form and pleced where they 111 be noot efreative. Yet thoy romaln bolierable in the I1ght of wht we of of the woon of the

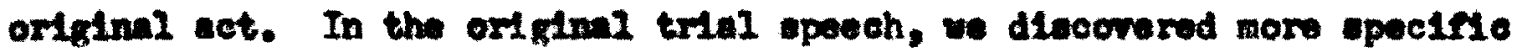
Kinde of etratefles in relation to the 1aw, whreas thoes in the play

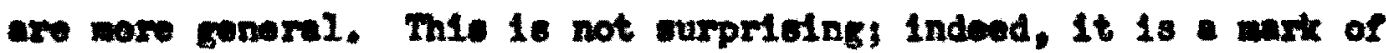
fatthrulnoes to histary. If in the play we find a genaral ropropente-

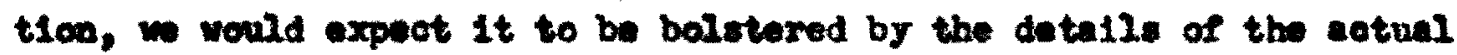
rrent.

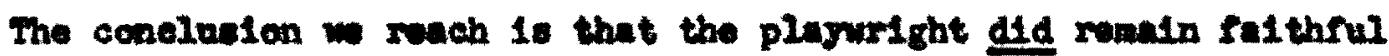

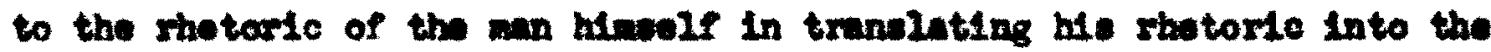

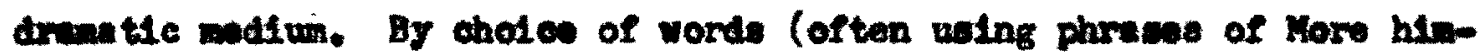

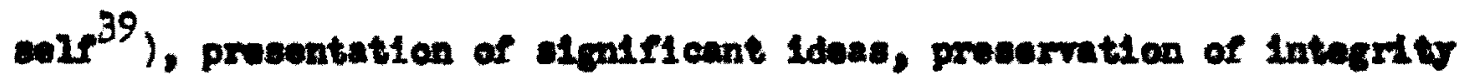


and arodibility of charactor and we of strategles, Bolt gives his andiences an honest representation of the rhetorical olenonte that mede Morv' discourse erfective. 
notes

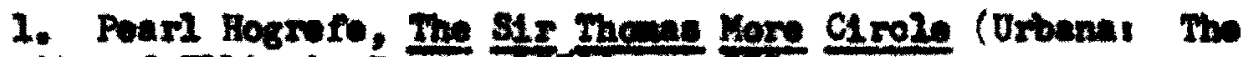
Untrarnity of IL1nois Prose, 1959), P. 253.

2. Mo1d.

3. N. W. Grogs, ed. Mes Bonk of S1r Thones Kore (Oxford

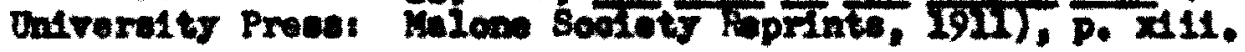

4. Iold, p. xix.

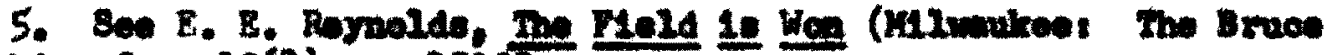
Foblening Co., 2968), p. 120 f.

6. 0regs, 92. 91t., p. 57 .

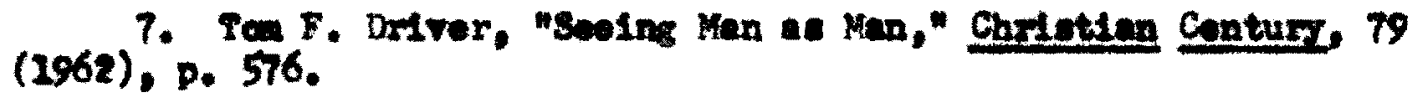

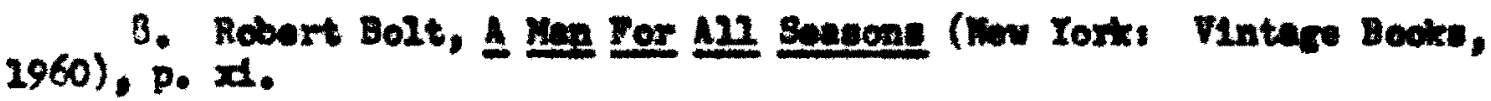

9. Ib1d.

10. Wultor Korr, the Inetro in Solte of Iteelf (Now Tork: Siman and Solmetar, 1963), p. 161.

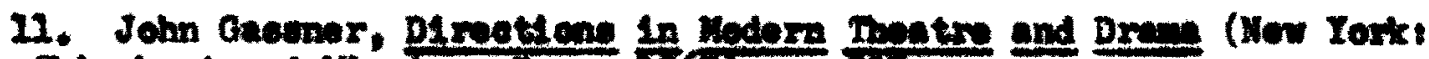
Helt, Fhinohart and Hnoton, Ince, IS67), P. 237.

12. Bolt, og. oft., p. xw11.

13. Kerr, ge. o1t.. p. 164.

24. Balt, ga. gt., p. x.

15. Drive, 10a, alt.

16. Bolt, g. att., P. 10-14.

17. Dold. . . 27-33.

18. onemer, ag, ost. p. 164 .

19. Bertold Breokt, in Toby Cale and Balen Crich Chinoy, eds.:

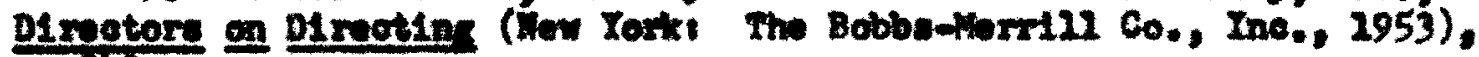
p. 240. 
20. Driver, 오. et., p. 577.

21. Reynolds, 오. c1t., p. 366.

22. Bolt, gp. c1t., p. 5.

23. Tbid., p. 6.

24. Tbid., p. 11

25. To1d., p. 13

26. See above, pp.

27. Bolt, op. a1t., p. 30.

28. Ibid., pp. 32-3.

29. Ibid.

30. Ib1d., p. 34.

31. To1d., p. 39.

32. Told., p. 57.

33. Tbid., p. 77 .

34. Tb1d., p. 81.

35. Tb1d., p. 88.

36. Told., p. 89.

37. Ibid., p. 92.

38. See above, p.

39. See Bolt, op. cit., p. xv. 


\section{GAPTER $\nabla$}

\section{DTEFRCA BNHosmen}

On Apr11 9, 1945, nuber of exwertions tock place in Bernany. Anong those who 1170 wre ended by the Nanl regine that day was a Protestant theologian, Dietwioh Bandeaffer. ${ }^{1}$ the vtory of how a Latheran paetor and tencher ans to be expented for political resecne by the offletals of the Thind Retch 1s a long and abeorbing one. It

1. told In conniderable dote1l by Bothge in his long thy blogrephy. For the purposes of rhetorlcal andyele, we will apply the dramatietse pontad and toll onough of the otory to alerify the rolationohipe batumen the Itre lowante.

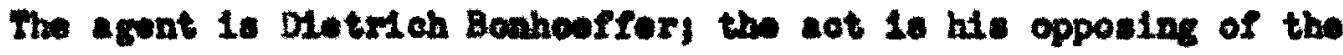

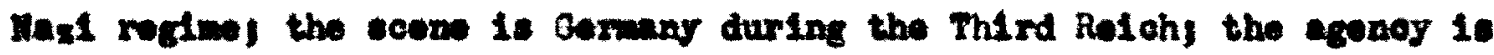

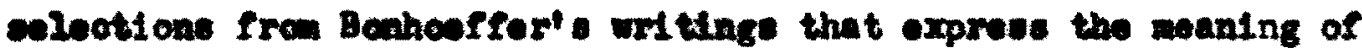

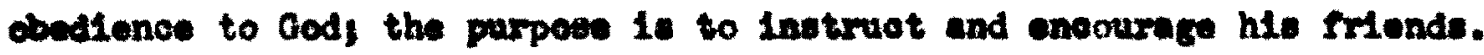

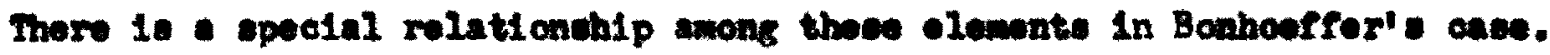
Apart from all fiv ecastituents thore is no rhotorieal "oront." Act, agency and parpose erv maninglese apart fren the agent and tho ceope and their rolationshp. The celeotod untinge wo ahall oxalns as tho ageney do not of themeelves elvoldate the sot or the purpose. Oaly by rolating then to Bonhoeffer and the situntion in with bo 11 ved w11 ther be ceen to be rhetorteally related to Bonhopfrer's parpose and to the act which soot hin his IIfo. 
In order to make the miationshipe as clear as possiblo we shall look firvt at the scono, then proosed to the agent, the sct, the purpose and the agenoy.

The rlee to power of Adolf Hitler and the pasil party took place gradululy during the yeare of the Wolmar Ropubl10, 1920-1933. ${ }^{3}$ when the long-amalted noment for Bltlor' take-over arrived, it could rightly be ald that "HItier's assumption of the Chanoollorehip of the Reich on Jamuary 30th, 1933, took place whin the correct forme prescribed by the Constitution." 4

The orente that took place doring the next fow wonths ended any necosefty for the Wasls to stay within constitutionel bounds. As the March 5 Ralohstag elootions approached, they felt the noed of etrongthenIng tholr position, alnoe thedr party had nover yet rocolved a clear enfority of rotes in eny elootion. They consplred to have fire eet in the Rolchetag bulleting and blawed it on thelr opposition. 5 In the gener al ocarumion and alam that followed, the Masle pustod through an edtet wot1tied "Proteotion of 8tate and People," the effect of which we rirtualy to anke Germany a pollce state. Howerer, the Corman peoplo coomod convinowd that it was for their oun good, for together, the kasls and the German Netionulist Perty elected majority to the Reiohstag. Lase than three weoke later, that body adopted an Enabling B121, thes dissolving itsele and putting "the Goverwont" In complete charge of the coontry." On July 14 , the Hasl Farty wa declared the only lagal polltical party In Oermany. $?$ On Ootober 14, 1933, Hitlor announced dernany' withdrawel from both the League of Fatione and the Dlesmement Conterence, 8 thus opening the way for roarwawent and freeing oermany from foretgm oblige- 
tione that might stend in the wy of the ventures Hitler bad in alnd.

Within the Mast party, there wae ome opposition to Hitler, partlealarly with regard to hls deofre to arold an arwed revolution. Bitler allenced th1s dissent in a manner that was to become typlesl: he had them maxdered. Between June 30 and July 2, 2934, somewhere In the vicinity of two hundred men ware killed, lncluding eoveral highly pleoed leaders.?

When, on August 2, 1934, President Hindenberg died, Adolf Hitler asoused his postion, rotalning the Chancellorship, and bocam in t1t2o as will as in fact, the dictetor of Germany. (Shiror records that the

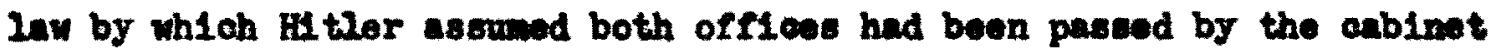
the day prior to Hindonberg's death.) $)^{10}$ Th1s manourer was aubatttod to the Cormin people for approval, and "In one of those plobisedtes which the Kasi regim handied with so mooh Firtuostty, the arrangement gained the consent of 38.4 adllion out of 45.4 willion roters. $n^{11}$

From that point on, the way was relatively oloar for Hitler to do whatever he vanted with and through the Gerran nation. He achieved a succession of brilliant accomplishnonts in foreign polloy. "Ho... shattered the oystem of European colloctive peots Inftiated by France, and . . gained the partnershlp of Poland, Italy and Japan with hie polloy of bilateral agrements. ${ }^{12}$

Ho also encouraged and Nigorously pursued a virulent and brutel anti-Semitian. Hitlor's om anti-jowish feelings can be traced back to hto jouth in Austria. ${ }^{13}$ Those of the Oerman people who aupported hin are probably more ocaplleated. Perbaps the Jows provided a handy scapegoat for the gullt foolings of a nation that was dejected after its 
humillating defeat in 1910.14 At any rate, oppression and persecution of Jews in the Nazl regime progressed until the "final solution"-the genocidal gas chambers-mas implemented.

Responses to the Nazi regime from the churches were varled. At the rery begiming of the Third Pelch, it was represented as a Chrlst1an government. Mau and Krausnick say of Hitler:

In his proclamation of Fobruary lot he gare an assurance that his Goverment would ' Alrily protect Christianity, which is our moral basis' and he concluded with the wordst 'May Almighty Ood show weroy on our work, gulde our will, bless our understanding, and farour us with the confidence of our people.' on February 11th, in the Berlin Sportpalast, Papen apoke of the 'new Chrlstlan Rolch of the German nation.' Whole SA (Brownahirt) formations went to church. In the Voelkischer Beobachter, the offioiel organ of the Iast Party, there appeared a leading article headed: 'Chrlotianty: the basis of Adolf Hitler's Goverment. 'I5

Th1s Illusion did not last lang. Nevertheless, there was a large sogment of the Stute (Iuthoran) Churoh that continued to profess Its loyalty to Hitler right up to the Inal dofeat of the Reich. Whon, In 1938, an oath of alleginnce to Hitler was rogutrod from the Protestant clergy in the diocese of Hunover, the rast majorlty of them took 1 t. 16

A falrly strable nuber of clergymen rofused frow the beginning to eupport the Nasls, and formed what was called the Confoselng Ohurch. A. time went by, they becane the terget of special pereecution, and gradually had considerable internal difficulty becaue of the restrietions and harraesment they suffered. 17 In apt te of the persecution, however, many clergywen remalned adamantly opposed to Hitler, oince his program had the effect of putting the state in the place of God. 18 HItIer's call for lebenaraun 19 Ied to the oceupation by Germany 
of Anstria in March, 1930, and of Czechoslovakia in March of 1939; the Invasion of Poland on September 1, 1539; and ErItain and France's declarations of war agatnst Germany on September 3, 1939. In April of 1941, H4tler's armies overcame Yugoslavia and Greece, and In June they attacked Pussia, wth whom Hitler had signed a non-ggression pact only two years before. Whth the entry of America Into the war in Jecember, 194l, German miltary resources became overextended, and, in spite of the efforts of the Japanese to keep Amerlca too busy in the Pacific to be effective in Europe, Cermany's enemies gradually got the upper hand and forced her and her military allies to unconditional surrender on $\mathrm{May} 7,1945$.

During these war years, the capacity of Hitler and his followera to inflict horror became monumentel. The systematic murder of thouaands of mental defectives and other "worthless" people was carried out, especially in Poland. ${ }^{20}$ Millions of Jews were exterminated, a ghastly process that went on right up to the time of the final capitulation of the Relch. 21 The full extent of this wassacre was kept from the publio, but Its existence was justifled by blaning the war on the Jews and proclatming them the sworn enomies of Germany. The Nazi Propaganda Minister, Joseph Goebbels, 8a1d such things as these in an editorial in 1941: "The Jews are our destruction." "Rvery German soldier's death in this war is the Jews' responsibility." "The Jews enjoy the protection of the enony nations. $n^{22}$

Hitler himself became more erratic. One of his closest advisors, Albert Speer, has written his Impression of Hitler during the later war yeare: 
In the past Hitler had had a fine sense of discrimination and was able to adapt his language to the people around him. Now he was unrestrained and reckless. His speech becase an overflowing torrent like that of a prisoner who betrays dangerous secrets even to his prosecutor. In his talk Hitler seemed to me to be obeying an obsession. 23

In the light of all these factors, it is not ourprising that a strong resistance movement grew up within Cermany, and within the Naz1 Government 1tself. There vere sone efforte to eatablish contacts with other goverments so that negotiation could be conducted if the NazI regine could be overthrown. 24 sventually, resistance centered in the plot to sesassinate Hitler. An attempt to do so was made on July 20, 1944, in HItler's headquarters near Rastenburg. 25 The attempt failed, and an estimated 4,980 people were executed by the Nasis in reprisal. 26

It was this discordant, shaotlc eetting that was the scene of Dietrich Bonhoeffer's Iffe and work. It was scene of authoritarian oppression, of strident militamism and of values ordered only one way-the state's. We will now look at the agent, Dietrioh Bonhoeffer.

Bonhoeffer twenty-seven years old when Hitler cane to power, having been born in Breslau on Fobruary 2, 1906.27 Thus, much of the direetion of his Ilfe was set before the Third Reloh spread its perrasive Influence over Germany. Nevertheless, his thinking and activity would be greatly altered by Nazi philosophy and programs.

Karl Bonhoeffer, Dietrich's father, was a famous psychlatrist and professor. The family home, both in Breslau and in Beriln, to which the Bonhosfers moved in 1912, was comfortable, happy, cultured and well-appointed. Through both family and frlendship there were contacts with some of the most prominent familles in Cermany. 28 
Dletrlch declded while he was still a boy to become a theologian, and apparently never seriously entertained any other possibility. He studied at the Tniversity of rubingen, spent several influential weeks In Rome as a stadent, and graduated from Berlin Jniversity. During these years, he became acquainted with the theology of Karl Barth, who was to remain one of the strong influences on his thought. He served as assistant pastor in a German congregation in Barcelona, Spain, during the latter part of 1923 and the first part of $1929 .{ }^{29}$ He returned to lecture at the thiversity of Berlin for a year, and then spent a year atudying at Inion Theologlcal Seminary In New York City.

Though Bonhoeffer was distressed by the riging nationalisa and anti-Semitiom during these years, he made no political comitment at this time. Bethge says,

- . In 1929 he took little Interest either in rightor left-wing polittos, but deroted himeelf solely to theology. Indeed after his first practlcal coumitment to Churoh and society in Barcelona, he returnod to his stuties with greator zeal. 30

Theologically, he wes advancing rapldly. His Ideas were being clarffled, and he was developing concepts and a atyle of his own. He continued to lecture in Berlin, and became active in the growing ecumenical movement. 31 Through his work on 1 ts behalf he made many important contacts with church leaders in various countries, contacts which became hIghly olgniflcant to the German rosistence movement. Fron the standpolnt of his theology, he took issue with the adulation being accorded Hitler. On a radio broadcast on February 1, 1933,

- his theological insight enabled him to warn his ilsteners that, ohould the leader iallow himeelf to succumb to the wishe of those he leads, who w1ll 
always seek to turn him into their idol, then the 1mage of the leader will gradually beccue the image of the "misleader" . . This is the leader who makes an idol of himself and his office, and who thus mocks God, 32

The last sentences were cut off the air for reasons that are not clear. 33 Bonhoeffer had the complete speech publiahed in a journal, and clrculated copies to his friends.

As conditions worsened, particularly with regard to anti-Semitiom, Bonhoeffer pondered how information about the true situation in Germany might be gotten to Amerlca, so that support could be obtained there for the Confessing Church. He cast his lot with those who opposed the State Church's collaboration with the Nazi regime, and began to apeak and write of the Church's responsiblilty to challenge the State when 1t believed the latter to be usurping its proper authority. His main concern was orer the Jewish question.

From late in 1933 to early in 1935, Bonhoeffer served as pastor to a German congregation in London. Bethge says of this period:

Thus the eighteen months he spent in London were dominated by the church struggle and its indirect effects upon the ecumenical movement. The latter took up a great deal of Bonhoeffer's time. His parish work, although not neglected, became increasingly involved in the struggle. His deepest commitment at this time, however, was to his reflections on the Sermon on the Mount and on 'discipleship.'

Hence from now on there were to be two different sides to Bonhoeffer. On the one hand, the man who was to dare more for the sake of the Church than most of his Irriends to whan the German church oppositton's plans--from which, before long, the Confessing Church would spring-were to mean just that ilttle bit more than they meant to his fellow militants; the man who behaved as though the 1deas of tomorrow were the realities of today and who, when the inevitable setbacks cam, was always ready to renew the attack. On the other hand, there was the Bonhoeffer who sometimes seened so reserved as almost to be a stranger to these struggles, who might suddenly be irritated by the Iimitations of his Confession; who was driven by quite different visions 
of the reslization of the Gospels. 34

Upon his return to Berlin, Bonhoeffer took orer the loederehlp of a Seminary for the Confesaing Church. He developed there a closeknit comunity with a rigoroud derotional life, and a profound inrolvement with theology. He wrote two books during this period, Lffe Together and The Cost of Diacipleahip. One of his trenulators says of these books: "These two works are the distillation of his fundamental message--ithat it means to live with Chriat." 35

State suppression of the churches increased in intensity, and the Seminary was declared illegal. It was some time, howeror, before it was actually forced to close. Bonhosfer's activities on behalf of the Confessing Church continued, especially h1s contacts with Chriatians in other countries. Iargely as a roult of ouch conduat, In 1936 he was forbldden by the State to preach or lecture in Beri1n. ${ }^{36}$ More and nore atrictures were adopted against the Coafessing Church with the result that

- . church activities oame to a rirtuel standstill and barely a day went by without alther the administration or the pastore of the Confesaing Church contravening one Law or another, or falling, Into some form of trap. By now it hed become quite Imposalble to serve the Confessing Chureh while remaining within the law. 37

The Seminary was closed in September of 1937, but 1ts activities were transferred to locel parishes where the work was continued pretty much as before, though the otudents were more scattered. Early in 1938, Bonhooffer was forbidden to enter Berlin. His father was able to get this modifled some, but Bonhoeffer was no longer froe to attend meetings there. ${ }^{38}$ he had many contacts with those who wore working in the realstance moveswent, and had elready been of holp to 
them by malue erequent trips out of the country to vigtt frends in the ecumentcal mevement who could mrovl te valuable asalotance. As the effectiveness on the Confessins Church lessened almost to the sero point, Bonhoeffer became more and noro active polltically until he was a fullfledered part of the restatance.

Bethre tells something of wat this meant to the young theologian:

For Aonherfer, at Geman theologtan and a Iutheran Chriatian, the stop into political action, orer whioh he oti11 hesitated, meant going Inth nev ond untravelled country. It uss cortalniy a mowenteus etep when one went over from silent opposftion to open Ideological protest and direct warning, as did Individual bishops and that memoranden of the Confeselng Ghureh; hut ft was a rarther and wore orltios otop into that politicelly ccontable revoluttionary planning for the puture. But that is what happenad in Bonboeffer' oace. For a long time he nerely knew and approred of what was golng on, t111 that knomlodge and approvel doveloped into cooporat1on. 39

Eonhoefser's work was interrupted in the sumer of 1939 by a trip to the inted States. Concemed orer the likelihood of bing anlled for milltary service which he could not bring himsels, ideologically, to accept, he consented to return to Inion Saninary in New York where he expected to resune his theological and ecumentcal work. However, the arrangements in Amcrica were not what he had expectod, and he folt a compulstion to be with his orn people when the time of the wort bufferIns came. It returned to Germen; before the ousmer was over. His own worde, in a letter $t$. Pelnhold Mebuhr, best explain h1s feelings:

I have made niatake in coning to America. I mist live through this difficult pariod of our national history with the Christian peopla of Germany. I w1ll have no right to partlelpate in the reonotruction of Ohristian iife in cemeny after the war if I do not share the trials of this tims with $\mathrm{m}$ people. . Chrietian in Cermany will fece the terrible eltermative of either willing the dafeat of thair nation in order that 
Chrietian civiliation may ourive, or villing the viotory of their nation and thereby detroring our civilisation. I know which of these alternative I puat chooses but I connot mike that cholce in eecurtty. 40

He returned to a grouing invelvement in the conepiracy to overthrow the Nas1s. His brother-1n-1ew, Hans Dohnany, wa en InMuontial Inyger In Berlin and a leader in the resistanes. Much of Bonheaffer's work wa done in conjunction with him. Be bogen a double 11fo. He cubotitute for alltary duty was portion in the Abwhr. or Intelligence Buranu of the HIgh Command of the Arned Forces. At the ane time be corved as a oourler for the reoletanee nerement and aseleted 1 to losdore with his considormble talente wherever he could. Bethge naye of Bonhourfort attitude tomand on of his fellow conopirator, an informars

It coend to hin appropriate in a oftuation into which a prosupticas bermin had mancourrod his country, and In whith 11 thowe who were oupable of action wor. euffering from paratrote of the connatones. So the patriot hed to perform mat in norwal tines is the setion of a scoundrel. 'Ireeson' had beocm trat patriotien, apd what was normaly 'patrotion' had bew ocas treacon. 4

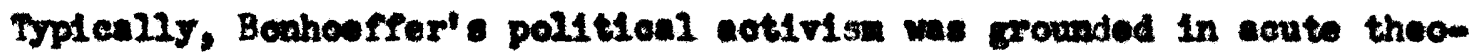

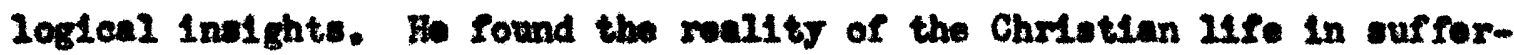
Ing for the sake of a juet anves, won though 1 t be an 111 ged one. He wrote Inter:

Man is ablienged to partiolpete in the oufforinge of ood at the hands of a pollese world.

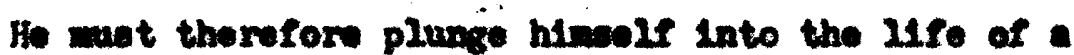
godiese vorld, whout atterpting to glose over its ungodilneas with a veneer of relicion or trying to tranefigure 1t. He mat 11ve 'voridy'ife and so partiolpate in the oufrexing of God.42 
The resistance morewont Pinily put all 1 ts energy into the plot to asenasinate HtIer and take orer the gorermment. Bonhoeffer was Involved In thil, of course, but took no direet part in the July 20, 1944, attempt. By that time, ho and Dohnanyl had been arrested and 1mprisoned. The arrests were ade on Apr11 5, 1943, at juet about the time Dietrich Bonhoeffer was to amomae his moent engagement to Maria ron Wodemeyer ${ }^{43}$

The Mret fow nonths of Bonboeffer's 1nprisoment were not as bad as they might have been. He won the friendehip of wny of the werders, and anaged to contimu his roading and writting. Some of his nost prorocative theologienl Ideas wre dictohod during this t1mo, and are preserved in Lattere and Papere frow Priaon. After the fallure of the July 20 plot and the Lleovery of anterials that clearly impliented Bonhoeffer, he was moved from prison to prison. As the All1ed axdes neared Berlin, Banhosfer we exeouted on April 9, 1945, at the Floseenburg concentration amp.

Fls long-tine friend, Blohop Bell of Landon, sald of hin in a monorlal servioe on July 27,1945 , In Londont

Hi death 18 a denth for Germany-indeed for Europe too. . his denth, Ilke hil life, ariks a faet of the deepest ralne in the witnese of the Confeselonal Pio) Churah. As one of a noble coupany of enrtyre of differing tradition, he represents both the reoletance of the bellowing soul, in the nwe of Ood, to the aeanult of ev1l, and also the moral and political rovolt of the human conselence sgatest injuetioe and ornelty. Ho and his fellows are lndeed built upon the foundation of the Apostles and the Prophets. And 1 was this parsion for fuotice that brought hin, and wo many others.. Into such olose purtmerahip with othor rosisters, who, though outelde the Church, ahnred the ane huanitarian and 11berml 1deale. .44 
The ecene and the agent are now before us. In describing them, we have inovitably been deacribing the aot as well. For during the Last several years of Bonhouffer's Llfe, agent and act wore one: opposition to the Masi regiw. Zeller notes: "Dletrich Bonhooffer - . once remarked: ' $A$ wan who thinks and cots reaponofbly need not worry about approvil. His only concern must be the Imperative need of

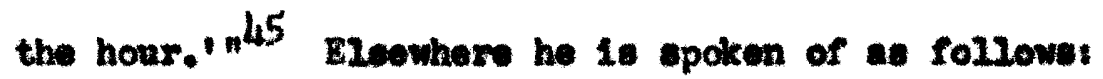

In a euming-up at the turn of the year 1942-3 he put the truth ruecinetiy when he wrote that 'the great maequerade of EV11' appearing 'In so many honourable and ceductiv gulces' had confueed all traditlown ethloel concepticas. 'The safe roed of duty,' of obedienos to orders, appeared to the Cerman Individual as a wy out of the diseconcertIng abundanoe of possible dectatons. But in fact it meant that be was catiorled with 'a anfe oobsctence instead of a clear one, 'and ultimately that his rendiness to serve the communtity wa mimed for eril. The power of evil could not be fought with the elmpilolty of a prinoiples only the 'rick of an cotion undortaken on one's oun reapensibility', oculd 'strike at the heart of the evil and overeane it.t. 46

Bonhoeffer saw his anti-Nazi activities as his duty to ood in that particular sttuation, and he took overy means avallable to carry 1t out. There were, of course, thole serles of Individual acts, not wany of which wre directly comected to a particular dicooures. But taken together, they 11luetrate mach of what he sald during his later years, putting into real action what he atated in more contemplative and theologieal torme.

The purpose behind both the act of oppostition and the ageney by which he expressed his opposition, was to inatruet and eneourage his readere in the midet of thair comon pertl. Onderiying all of Bonhoeffer's iffe and work was hls detormination to obey God at all coste. 
When this meant opposing the Nasis, that is what he did. At flrot, ho belleved that this should be done wthin his duties as a churchmen. But when he becane cominced that his opposition must be oarried into the polltion arom if he ware to centimu to abey God, ho did wo whole-hartediy. Drawing on his conviotion, ho wated to dive every poselbie support to his frionds and othore who noeded It. Wh thet purpose, he wrote of the meaning of obedience to ood in mach time as h1..

Benhoeffer vrote acmething in his Ethice that helps us to underatund his purpose:

Ood's comenndwent is the opeoch of Ood to win. Both in 1 te contente and in 1 ts form it is concrete spech to the concrete man. Cod's comenchent loures man no rocm for epplication or interpretation. It leaves room only for obedienee or disobedience. Cod's comandment camot be found and knom in detachment from tim and pleses it ean only be heard in a local and tesaporal context. If

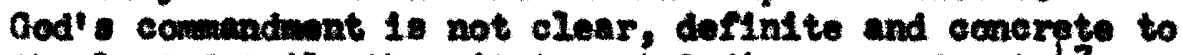
the last detel1, thon it is not dod's comandment. 47

For Bonhoerfer, Oed's comendinent was opposition to the Haxla, oren to

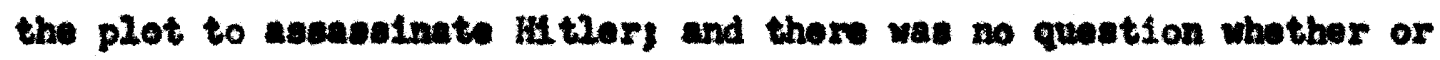
not to obey. It we this riew of God's somand that he wibhod to ahare wth hie readors.

The agonoy in our rhetorion investigation is eelected mitings of Dietrich Bonhoeffer. Those enlectione are made on the beale of the following exiterias thoy have rhetorical intent; they are related to the puxpose already atated; they ropreasnt a pertod or wont that wae

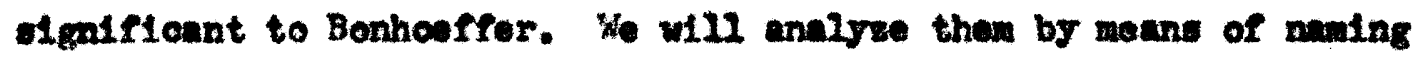
strategies. 
The first passage is from an essay entitled "After ten Years." 48 It was written at the end of 1942 and sent to a few friends as a Christmas message. It's purpose was evidently to clarify the confusing times in which they lived, and to encourage his friends to remain steadfast in the nidst of oppression. Hence he says, "I belleve God will give us all the power we need to resist in all time of distress." 49 It had been almost exmotly ten years ince Hitler's accession to power, and now Bonhoeffer's arrest seemed iminent. 50 It was an spropriate time for a brief but important statement of his unwavering obedience to God.

He beglns, "The great masquerade of evil has wrought havoo with all our ethlcal preconceptions." 51 His strategy here 18 exposure in a two-fold sense. He is exposing the masquerade," and he will proceed to expose the ethical preconceptions which evil has undermined. Using the atrategy of parallellan, he goes on, "Thts appearance of eril in the guise of Iight, beneficence and historicel necessity is utterly bewildering to anjone nurtured in our traditional ethicel systems. ${ }^{52}$ "Light, beneflcence and historical necessity" clearly refer to the Naxi prom paganda by which Hitler attempted to convince the Germans of the Indispensability of his lesderwhip (an attempt whtch was largely successful). But Bonhoeffer's phrase "appearance of ev1l in the guise of IIght" is intended to expose it for what it wast depravity. Ifs choice of language sets the two opposites in otark contrast and prepares the reader for the exposition which follows.

He then rofere to the "Traditional ethical gyatems" one at a time and uses a strategy of systematic attack to support his orfginal atate- 
nente. The f1rst is rationalism. Me charges the rationaliet with "o nive lack of realism. "59 Using atlitary motaphor, he asserte:

- . In the meles of conflicting forces he gots tmaplod upen w thout huring anteved the ilightest effeot. Dieappointed by the irmtionality of the verld, he realised

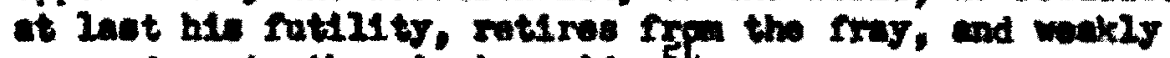
currondere to the cinding olde, 54

This atrategy 18 olooe to nane-calling. Diappointed, fatility, nt1res, wakly-thees are pejorative terme.

The acond ayoten is norel fanticiem. Ho insediately wane his

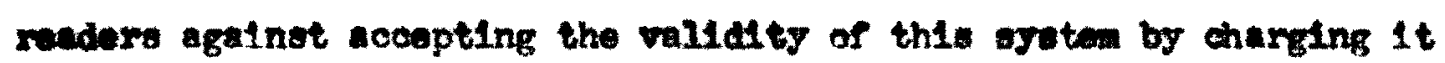
with "total collapes." 55 He imputes to the adrocates of this ayatem a woral purfty, whioh might eound 11ke positive value. But Benhomffer makes it oleer that its value is 11luoory, that it is in fact a atwinent. Its strongth exdsts only in the inagination of the one who balleves he has 1t. He uses almile to expose the weakmass of this ayoteru: ". . IIke a bull he goes for the red reg inetead of the nan

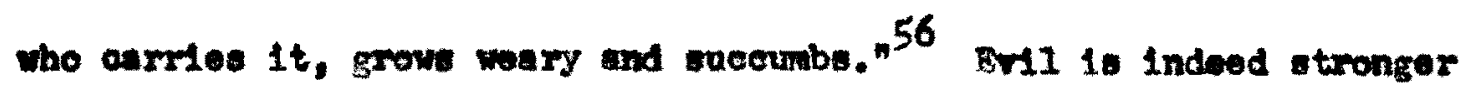
than this kind of Ifthtecumese, he infers.

He next attacks ooneclense. Conncience is a arucial conoept in this atudy. We have used 10 to refer to an ultimate conmitmont to the Mghest value of ond. I1fe! in the ease of both More and Bowhosffer, Ood. It reprwents a comitment wieh cennot be abrogated without a degree of elf destruction. In that semes, coneclence can symbolise Bonhoeffer's obedience to bod and hil determination to romatn faithrul to the Christian 0ospel as he underetand $1 t$.

That is not the way he uees it in this passege. Here it noara an

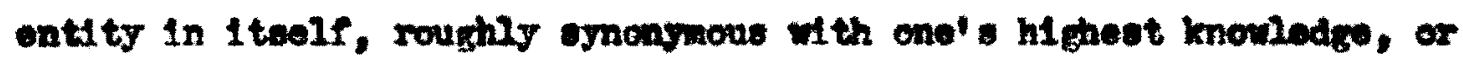


best intentions. It is something on which one relies solely, rather than a guide to a higher authorfty, such as God. It is an thical oystem, and as such Bonhoeffer calls it insufflcient. Evil approaches the man of conselence "In so many specious and deceptive guises that his consclence beccmes nervous and vacillating." 57 a strategy of derogation is apparent in "apecious and deceptive," while "nervous and veoillating" are pat in a consequential relationship to such an encounter with evil. He warns, "In the ond he contents himself with a salved instead of a clear conscience. ${ }^{58}$ The close proximity of "salved" and "clear" form another of the contrasts by which Bonhoeffer underscores the evilness of the enemy that is being faced. An important clue to h1s general attitude toward consclence is found in the statement: "If a man relies exclusively on his consclence he fails to see how a bad consclence is sometimes more wholesome and strong than a deluded one." 59 In other words, conscience must not be ultimates only God is ultinate for Bonhoeffer.

Duty is the next ethlcal alternative of which be disposes. Ho points out that nthe responelbility for the imperative rests upon its author, not upon its executor." 60 But this is a way of evading decielon and responstbility, and "the man of duty will in the end be forced to give the devil his due. ${ }^{61}$ The strategy is wamings he who follows blindly w11l discover that the one he follows will eventually be wrong. "What then of the man of freedon?" he asks. He ralnes this position highly, but warns, "He must bevare lest his freedom should becane his own undoling. For in choosing the lesser of two orils he may fall to see that the greater ev1l he seeks to avoid may prove the Iesser." 62 The 
"fallure" here would agnin be making oneself his highest authority.

The last ethieal syaten ho examined is private firtae. If introduces this with the pejorative phrases: "Some sock rofuge... In the sanctuary, ..." ${ }^{63}$ thue setting this position astid as undeatrable for the person who would realet orll. Such man "are compelled to seal their Ilps and shut their eyes to the injustice around them on Such a reaction to injustice is the opposite of true othics. If they are to remain "pure ercen the defllements incurred by reeponsible action," 65 they can do so only "at the cost of self-deception." 66 He is using the strategy of ridioule to attack this poution. Fe warn that "that whioh they leave undone w12 st12l torment their peace of wind. They wiI elther go to pleces in face of this disquiet, or develop into the nost hypocritieal of all Pharisees." 67 This is the harabest juigment of any he makes ageinst the varlous ethical ayetems. It reflects his on count tment to active obedience in the conorete situation.

An alternate nawe for the strategy ued throughout these exaninatione could be 1conoclen. Ioonociesa is the absttaring of Idels, and each of these syotems might be oonuldered seored by its adherente. Thus an attack on them could appear to be the breaking of samething holy, whereas to Bonhoefrer it is the removal of felae gode.

Having disposed of then all to his atiafaction, he efves the only postiton he considers temable. It is quoted here in rull.

Who stands his ground? Only the men whose vitimate oriterion is not in his reasca, his prinoiples, his consolence, his freedon or his virtoe, but who is readr to sacrlftee all these thing won he is exlied to obedient and responstbie setion in fatth and exclusive allegtance to God. The rom upona1ble man eecks to makg his whole Iife a responae to the question and call of 0od.68 
The strategy 1s personal testimony. The last sentence, which states the theme of the passege, is falth statement. That 18, it cones out of Bonhoeffer's falth and his relationoh'p to God, rather than resson or loglc. It 18 a bellef to which ho besis witness, and which underlies all of hle vriting and his actirities.

If falth in God be pranted as worthy uitimate comitment, then wat Bonhouffer agys here is conslatent, and, to that extent, oredible. Thowe who reselved this material would recognize that the rery act of alroulating such ideas was an act of courage. They would know further that ho had been buy prootiolas what he preached for thow ton years. The wy in which he pat his theology to the test in his own actions would ertablich ble oredibility. To the extent that the readere realieed the relationohip between word and deed, they would accopt Bonhoeffer as - man of integrity.

According to the previously noted oriteria of oxentive lenguage, efgnifloant 1toas, intogrity and credibility, this is good rhotorleal discouree. In tems of strategles, it emplnys evrerel, with the general strategy being problem colvinf. That 1s, he prosents a oftuation which he represents as bed, he ogrotematieally demollobes the tredit1conal responsed to $1 t ;$ then he gives his conetructive anower.

The second seleotion to be anmiysed is a portion of an sesuy written while Bonhouffer was in prison and ent1tled "Thoughts on tho Buptiem of D.W.R." ${ }^{69}$ It is writton as though addreseed to the ohild (Bonhoarfer's Godeon), and wat sent to the ohlld's father. ${ }^{70}$

Bonhoeffer begins by referring to the anelent Chriatian Itwal being performed over the ohild without the ohild' knowledge. "But," 
be deye, "wo too are being driven beck to flret princlples." The ueo of andogy merves to turn the meeage toward the contemporary situntien. He goes on:

A tonoment and redemption, regeneration, the Holy Ohost, the love of our oneutes, the wroes and reverrectl on, Itfo in Chrlat and Chrletien diselplochtp-all thow thinge have

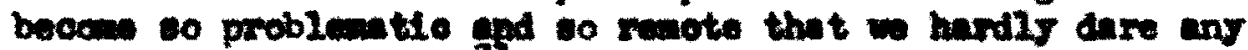
wore to speak of them, 71

To nawe those traditicenal Christian theologloal cetegorles and then say that "we hardly dare to speak of thew," is a rath $x$ abrupt way of nolne - otrategy of unvolling. For to the sensitive reader the truth of what

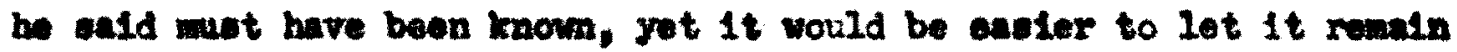
uneald. It is evidence of the profound intellectula searching which Bonhoeffor was undertaking. Ho continues, "In the traditional rite and onremonles we are gropling of ter sowething new and rwolutlonary without being able to understand 1 or utter it jet." ${ }^{72}$ He ereates a atrong contrast between the treditional and the new, thue pointing to the foundations and the future of falth. Permanenes and ferment, otability and hope axe Intermingled. Howerer, the Mack of undaratandIng" Iewres the expheale on unoertainty. "That is our oun fallt," ho anse, 73 and proceeds to tell why.

Daring these youre the Chureh has foupht for owfpreservition as thoogh it wore an ond in 1tevlf, and has thorvby loot ite abance to epeak a vord of necuolliation to wankind and the world at Iarse. 74

Thie is intended to be condemnation of the etroagest sort. For it is procisely this "word of roconelliation" wich is the Chureh's prieary

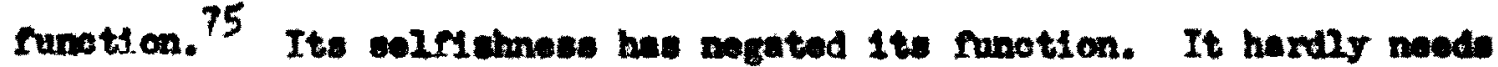
to be added that the world in which Boshoeffor wae wry tins noeded that word of reconolization in the direot wy imacinable. 
As a consequence of this loss, the Church w111, for the time belng. confine itself to prayer and lolng right by ali mon. But a new day is comirg.

It is not for us to prophesy the day, but the day w111 cane when wen vill be ealled aguln to veter the word of ood with such pover as w11 change and renew the world. It 112 be - now Ianguage, whigh wil horrify won, and got orembel them by 1 te poirer. 76

The atrategy of prediction is amployed hare, along with the otretegy of tebtinony. For no such prediction can be made on the basis of available "facts;" but only on the basls of falth. The language is simple and dear, and creative becanee of 1 te atrong combinations of 1deas. Thare I6 nothing unusual about the vords, "men will be called sgaln," bet in the context of the deeperate times and the sambre tone of the vordi preceding, they have apecial vigor and optiniom. The optinion is reInforced by "change and renew." That the languge which wi11 oowe wi1 "horrify wen, yet overwhaln them by 1ts power" points to the extraordinary nature of the expected eveat. "It wi2l be," he goes on, "the langiage of a now righteouness and truth, a language which prociatw the peece of ood with men and the advent of his kingdom." 77 Here is the strategy of reassurance, for these are more traditlonal coneepts, and though the language way be new, it will be spaking of known realitios. "Until then the Chribtisn cause will ba silent and hidden afreir, but

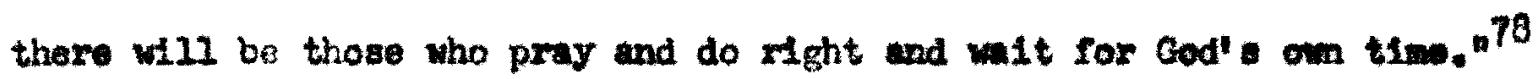
The reassurenco is contimeod, but there is added an Implied vanning for ther was still a very vistble and vocal Church, oven In cermany. Bon-

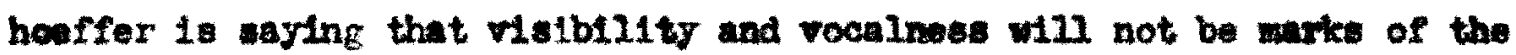
Churah. 
The whole passage is a reallstic appraisal of the grim situation of the Church at that time, and an optimistic look ahesd. It seems an appropriate message for the occaston, impressive in the sane way thet the birth of a child is Itself a polgnant and a hopeful event in the midet of tragedy. The rhetorical value of the passage canes fron a combination of strength and clarity of language and the way in which it bullds on the meaning of the event to which it is addressed.

The last passage to be considered is a portion of a letter writton fram prison on July 21, 19l4. Th1s was the day following the fallurv of the long-awaited attempt to aseassinate Fitler. Since his activity in comection with that attempt was largely the cause of Bonhoeffer' inprisonment, the fallure must have been terrible disappointnont to him. Had it oucceeded and the resistance leaders been able to take over the govermment, he and others would have been freed to begin the taok of building a now Cermany. As it was, the danger of their position was greatly increased. The letter 18 written to Bethge and published in Letters and Papers from Prison. 79

He begins by saying that he w1II not discuss theologion problems this time. "There are times," he says, "when I an Just content to 11 re the Iffe of falth without worrying about 1ts problens." ${ }^{80}$ In 1ight of the circumstances, this indicates that Bonhoeffer had achieved conaiderable mastery over any motional turmoll he may have been euffering. of course, he could not have eaid anything that directly roferred to the events of the previous day because of prison censorship, ${ }^{81}$ but even so his words show a tremendous innor unity that could not be ahattered by outer dlaaster. Hil strategy is teatimony, not, probably, deaigned 
to be pereuasive, but powerful in 1te simplicity.

In splte of his disclainer the beginning, he turns to theological matters: "During the last year or so I have cowe to appreclate the 'worldliness' of Chrlstianity as never before. ${ }^{82}$ He uses a ctrategy of paradox, because he attempts synthesis of two concepts, world11ness and Christlanity, that have traditionally been thought to be in opposition to esch other. He explaing further, "The Chrletian is not a hono rel1glosus, but an, pure and elmple, just es Jesus was man." 93 The strategy used is a shook tactic, for to say a nohristian is not a religious men," goes against the ordinary way of thinking of Chrigtianity. Though it may not have shocked the reciplent, who shared my of Bonhoeffer's views, it would st1ll have that effect on many readers todny. The worldliness he has in mind is "something in which the knowledge of death and resurrection is ever present. ${ }^{84}$ Ints is the strategy of explication, for he is now showing that there 1 more depth to his wee of words than might at first appear.

later he says, "I thought I could acquire falth by trying to 11 ve a holy 11fe, or somethlng like 1t." 85 He 18 ot1ll disaasoeiating concepts that had traditionaliy been Iinked together. Then, he says, "I discovered and am still discovering up to this very monent that it is only by living completely in this world that one learns to believe." 86 The use of the phrase "this very moment" 18 signifloent in view of the day on which he used 1t. Did he consider the catastrophic events of the day before a leaming expertence? Fridently he did. When he ays that "It 18 only by Ilving. . that one learns to bellere," he is once again doing a complete about-face wth traditional concepts. A dogmatio 
approach wowl be that one learns to live by belleving. Bomhosffer shows by this recurrinf atrategy the orlginality and frochness of hio thinkinf. The langonge is creative in that it makes these novel polnte of riev olear and arreating.

He makee further explanation of his polnt:

Th1s to what I mean by worldliness-taking $21 \mathrm{fe}$ in one's otirlde, with all 1 to duttes and problems, 1ts nucoesses and ruliures, 1te expertences and helplessnoss. It is In such . Lfe thut threw oureelves atterly in the anve of God and partietp te in his autrering in the vorld and wateh wh chrlot in Gethemane. . How can cuccese malke us arrogent or fallure load us astray, when w partiotpate in the oufferlags of lod by Iiving in this world?

He employe the atrategy of clarifleation to how thet to bo voridiy 10 not to abandon nod, bnt to cone closer to him. The raforonoe to Chriet In Gethemane is an 1dent!fleation strategy which would realind he reader of opottlo time of emotional and opiritual ouffering in the 117e of Jeuns. Thts would serve as encouragenent by example, and support Bonhooffer's point concerning Chrlotian worldisiness. The Iast entence, the rhetorlcal questlon, employs the etratogy of reassurance, asearting that the IIf Bonhoeffer is aspousing is the Iffe that bringe man in closest touch with God.

He says of the point he has been discussing: "I an glad I have been able to learn 1t, and I know I could only have done so wong the road I have travelled. ${ }^{88}$ This is a teotimony to his personal acoeptence of 811 that has bappened to hin, even his gratitude for what it has brought to him intellectually and apiritually.

The ablitty of this letter to influence people is found partiy in the language and the otrategles, but aloo in the total oftuation It 
represents. Knowing that Ponhceffer had partictpated fully in the sufferings of the world, and that he did so convinced that he was obeylng God, gives added authorfty and credib131ty to what he says. Fram a theologtcal point of Fiew, his ideas are far from completely worked out, but the great amount of attention given to them in books and journals shous that they have the power to move people to further investigation of his thought and 1 ts meaning. In that senee, then they sre rhetorically effective.

With these three examples of Benhoeffer's diecourse before us we will now consider the total effect of his rhetorle. Here the dramatiotio pentad is of particular help. For Bonhoeffer's rhetorical power is a product of all the elenents we have examined. Though he showed signe very early of great theolorical ablilty, some of hla most provocative insights were direotly related to the struggle against the Magis. Would they have oome out of quiet, sheltered univeraity existence? We do not know. Shat we do know is that they came from the cauldron of persecution and resistance that Benhoeffer IIved In for twelve years. Not only was that scene an integral part of the source of Bonhoeffer's thought, it was the testing ground for 1t. He not oniy sald what he belleved, he lived it and he died because of it. This is a very influential witness. Ao we put words and acts together, we discover compelling comitment that moves us to consider it earefully. Bonhoeffer called it obedience rather than consefence, but it is for hir an ultimate coumitmont upon which nothing can Infringe. It is an outetanding example of how thealogy wedded to practice can have rhetorical effectiveness.

In revlew we may see that the following 1deas emerge as centrul to Bonhoeffer's conviotions: Mrst, he recognized evil in the Nast regine 
where mary saw good. Thls is wade especially clear in the discusetion or Bonhoeffer as agent in relation to the scene. It also comes through In the stratery of exposure in the passage from "After ten Ieara." Closely related to this, secondly, he belleved that the churoh in Oermany had been unfaithful. We find this in the attack on tradtulonal waye of reacting to evil in the essay, "After *en Years," and even more in the strategy of unvelifing in "Thoughts on the Baptiom." There he cleo uees the atrategy of condemation agalnst the church. Third, he has a prom found fatth in coi. This is one of the main themas of the analyois of Bonhoeffer as agent, and 1 f found in the rhetorio in the exany exter of the use of testinony as atrategy to show ind persons falth. It is particnlarly striking in the letter of July 21st. A cansequent of this 18, fourth, is determination to obey cod in all situations and et whtever sost. Ti1s is set forth in "After Ten Years" as the oolution to the problem of meeting evil, and underlies the testinonias of all three pessares. It also is prominent in the analysis of the agent. Fifth, wo belleved that there was gomune hope for the future, baed on the goodness of thd Tis 1dea is expreased in the Baptian essay by the otrategy of prediction, and in tho letter through clarifleation and identification.

Sotrleh Bonhoeffor brother-1n-1aw wrote a very apt cumary of this kin of nersusalvenesa:

Thus Tonherefer' If for the future. De has set a med for a now type of true leadershtp Inspired by the goopel, dally realy for martydom and death and labued by new optrit of chriatian humanim ary creative cense of clvic duty. The rotory wich he has wow wa a vetory for us all, exgueet never to be indone, of love, 11ght: and 11berty.? 
noms

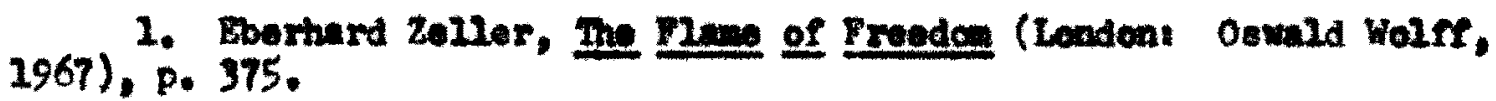

2. Bberherd Bethge, Pletrloh Bonhoefrer, trans. Brlo Noubacher ot a1. (How Yorkt Harper how, 1970).

3. A dotulled cooount of the period will be found in Willian $L$.

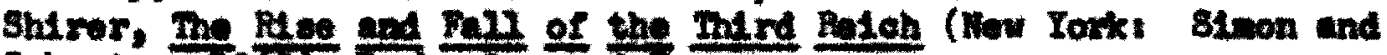
Sohwster, 1960), Boor ono and Two.

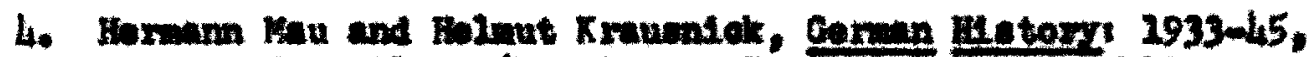

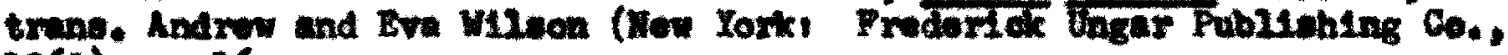
1963), p. 16.

5. Dold., p. 23 .

6. Dold., pp. 25-7.

7. Fold., P. 19.

3. Mold., p. 61 .

9. Thid., p. 52 .

10. Shi rer, ge. elt., p. 226.

21. Mau and krauentek, ge. adt., p. 5h.

12. Dold., p. 66.

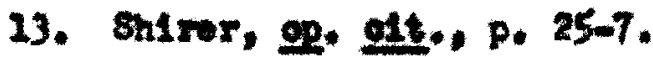

14. Wau and Krausntok, og. eft., p. 69.

15. Bdd., p. 15.

16. Shirer, ge. e1t., p. 230.

17. TbLd.

28. Fold., p. 240. Sec aleo Bothye, op. O1t., pp. 483-5.

29. Mau and Kroneniok, p. 72.

20. Iotd., p. 223. 
21. Tbid., pp. 126-7.

22. The Nez1 Ioars: A Documentary Hilatory ed. Jouchim Romak (Englewood CIIT78, r.J.1 Frontice-Hat, Inc., 1969), p. 156.

23. Albert Speer, Inolde the mind Reioh, trans. Richard and Clare Winston (Nex Yorks The Meckinan Co., 1970), p. 305.

24. Harold C. Deutach, The Congdracy Alainat Hitier In the Twilight War (Minneapolis: The Un1versity of Winnesota Pres8, 1968), pp. $38 \mathrm{ff}$.

25. Zeller, op. alt., pp. 301fe.

26. Shirer, op. o1t., p. 2072.

27. Bethgo, ge. it., p. 3 .

28. Ibid., pp. lefe.

29. Tbld., p. 70.

30. Tlo1d., p. 93.

31. Iold., p. 178 .

32. To1d., p. 194.

33. To1d.

34. Tb1d., pp. 256-7.

35. Dietrleh Bonhoeffer, Lfe Together, trans, John W. Doberstein (New York, Harper \& Row, Pabilohers, 1954), p. 11.

36. Bethge, gp. eft., p. 426.

37. To1d., p. 484

38. Fo1d., p. 503.

39. Toid., p. 526.

40. To1d., p. 559.

41. Mo1d., p. 529.

42. Dietrioh Bonhooffer, Lettere and Papere fran Pricon, ed. Bberherd Bethgo, trans. Regtnald Faller (Now York: Tho Mackilian Co., 1953), p. 222.

43. Bothge, op. oft., pp. $691,695$. 
44. Ibid., p. 833.

45. Zeller, op. cit., p. 207.

46. Mau and Kraumiok, op. G1t., pp. 135-6.

47. Dietrioh Bonhowffer, Bthles, ed. Bbertard Bethge (New Yorkt The Mackfflian. Co., 2955), p. 278 .

48. Bonhoeffer, Latters and Papere from Prison, pp. 15-34.

49. Told., p. 27.

50. Bethge, op. c1t., p. 686 .

51. Bonhoeffer, Lettere and Papers from Prteon, p. 27.

52. Io1d.

53. Ibid.

54. Toid.

55. In1d.

56. To1d.

57. Ib1d., p. 18.

58. Io1d.

59. Thid.

60. Ibid.

61. Inid.

62. Trid.

63. Fold.

64. Tbid., pp. 18-9.

65. Ib1d.. p. 19.

66. To1d.

67. Ibid.

68. Th1d.

69. Th1d., pp. 179-188. 
70. Bethge, ge. aft., p. 612.

72. Bonhonfrer, Lattere and Pepere from Priaon, p. 187.

72. nold.

73. Ib1d.

74. Indd.

75. Bonhowfter, Ethaton, p. 301.

76. Bonhoeffor, Letters and Pepare fron Pricon, p. 188.

77. To1d.

73. Iold.

79. Tosd.. pp. 225-7.

80. Inte., D. 225.

82. Inid., p. 21.

82. Io1d., p. 225.

B3. Fold.

84. Iotd., p. 226.

65. Tb1d.

86. nold.

87. Thid., pp. 226-7.

88. Tb1d., p. 227 .

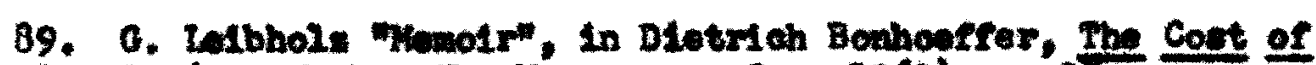

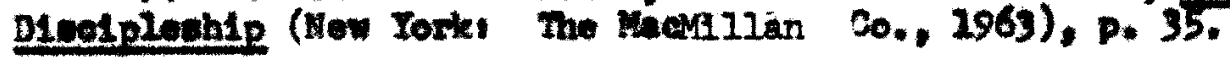




\section{GA PTRA $\mathbf{7}$}

\section{THE CUP of TharbLrat}

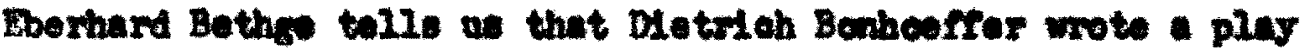

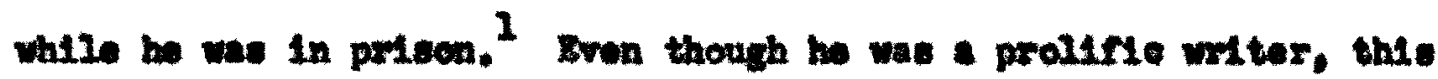

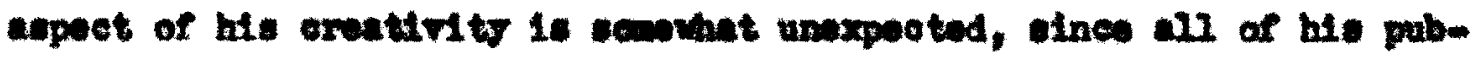

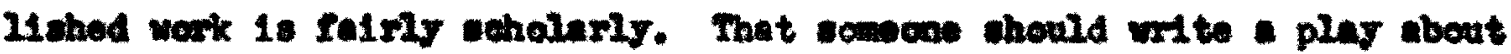

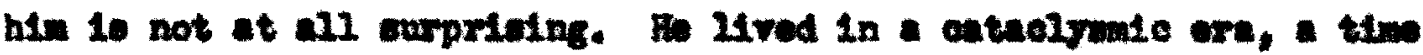
and plnoe of mal tragedy. Ho ande most notable stund from a point of viev that was, in thet the and plice, woural. He was an of

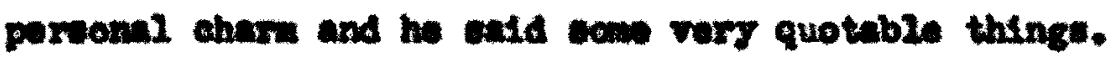

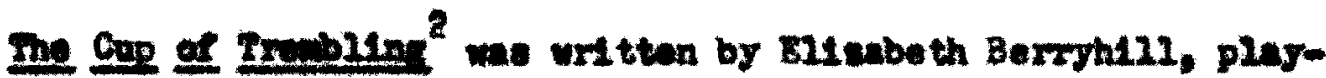

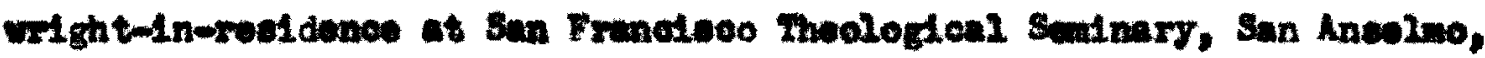
Culffornta. It has boen produond by nuber of thentre group in virlous parte of the contry. Mas Berryill otates that it is an

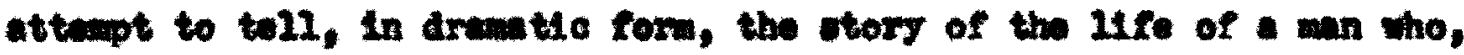

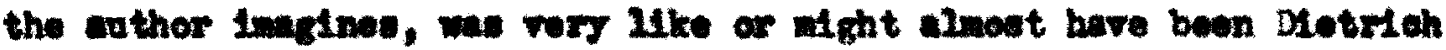
Bonhoeffor." 3 The num of the central ahernoter in the pley is Exich Filedhoffer, but many of the wonds he unes aro those of Boahooffer.

The plagwight bes ecverel interveting thestrical dovioes. In

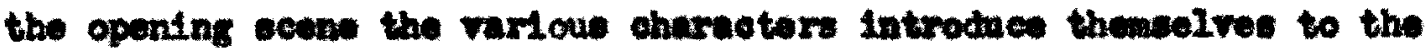
adience os though they wre the cotunl pople of the sayl axeopt for Erieh, whoe part is telcon by an cotor tho we the exweutioner at

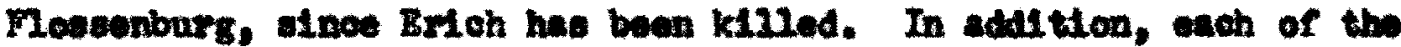


oharacters fllis ane or more other roles. This doubling etrategy reduces the muber of players and furthers the eense of reality by nuding It appear imposeible for ocm of the people tho participated in the erents to be present.

A wde variety of 100 les is auggested by hiving seene change Indieated by lighting dovices. Sopnery and costuming aro intended to be kept afiple. The purpoes of this is to focus the attention on the characters and their tory.

In applying the pentad to the play as agonoy, we have the playwright as agont, the statement of Bonherfer's Ilfe and meseage as aot, the theatre-going pablic as soent, and the charing of Information about an nubual 14te as purpose. We may saopect a noro profound purpose than that, but the suthor givea no woh Information in the notes. She does say that the play "1. Intended for perforannee in elther a theatro or a church." 4 This mey wall wean that the playrright conneots the Importance of Bonhoeffer' cembitment to her purpoee. Purhapa there is a mestge for Americans in the great atruggle of the Cerman thoologian. At the least, we may assume that whutever rhetorleal strength the play has was Intended by the playmelght.

The ecen is the Amorican thentre-going public, including that portion of 1 t that is more $14 k e l y$ to se play that is presented in ohurch than in a thestre. This means an audience of people who will tend to be traditional in their thinking on rellglous 1 soves tho may have I1ved through the perled when th1s country was Aghting the Bermansm my oven have fought there-mut tho at least know the period as on of ond ty between the two countrled. A280, when a play Iike this one which 
has had no ccumercial run is produced, people may expect a measage in addition to entertilment.

The act is the presenting of Dietrioh Boahoeffer in such a wa that his oingleminated comat tment to obeying God as ho understands that obedienoe is made clear to the andience. It is not just a "2ife" that 1. portrayed. It 18 the facthrulnes in that 11 fe that made it out standing which we se.

Within the play, the agent is Brioh Fyedhoffer! the act Ia his opposition to the Nants; the agency 18 narrative, conversation and Ietters, "gpoken or read," the scene is primarily Germany) the parpose 1s to expreas an iternative way of 11fommo dinatrically oppesed to the Nasi style.

We w1I examine the play and nowe the etrategles which are used to make the act and the purpose clear.

The play beglns with in execution seene, played in semi-darkness. The sound of the trap being eprung to heard, and a chorus of rolces beIns to recite "Death," Iram Bonhoeffer's pom, "Stationg on the Road to Freedon." 5 This is a poem witten by Bonheeffer while he was in prison. Its tour atanzes are sub-tilled "Dlselpline," Motion," "Suffering," and "Death." Becauee 1te ldeas roughly parallel the atages of Bonhoeffer' thinking, it is ued at rarlous pointe in the play as introductory weterlal for jor traneitions.

At the concluston of the recitation, the chnracters introduce themselves and set the seene. This is a strategy of definition, a way of establiohing contuct wth the audienee as well as informing them of beckground information that is important to the action. 
The actor-execationer who plays the part of Erich tello who he 1 s and ayre, "Perhaps it wa because I vas an actor that I coald do what I did-perhape 1 tas because I could pretend that It was not I but eomeone else desling with the rope and the trap under the shadon of that torrible tree. ${ }^{6}$ This is the strategy of reveling--giving inaight Into the horror of what took place in those executions, and reatinding us that human belinge wore imvolved on both onds of the rope, as 1t were. He concludes,

I can only pray that I may bring Pastor Friedhoffer to Iffe in this place tonight as joyousiy and moaning ruliy as his splrit lives in eternity. I can only hope that you will interpret of attempt to do wo as the act of repentance for which I intend 16.7

To epeak of "his epirit. . In eternity" 1 to tomploy theologleing In order to eatablish a religlous aura about the menory of the principal character. The spesch wloo uses apology, agein reinforeing the perwonal Image of the executioner. He is not allowed to remain faceless nonent1ty.

The Mother reads the Arst of the stansas, "DLecipline," and gives acue blographical facts to Introduce Erich as a child. It is a etrategy of characterization, eerring to begin to build the Inage of Erich as a person of groat Innete mental and apiritual acumen. Mordng quickly to the years of his theologleal training. Erioh playe scene Wth "the great Profeswor," presumably Karl Barth. Erich breaks into a cluse discusation with quotation from Iuther: "The curse of a godlese man can sound more pleasant in the earg of God then the hallelujah of the plous $t^{8}$ Voing the atrategy of brashness, Erich ahowe his attruom tion to unusual views, as well as his wllingness to experiment with thea 
In the company of others. There is acmething af Irgatience ith unthinkins traditionaliw hore as well. This is emphaelsed even nore as

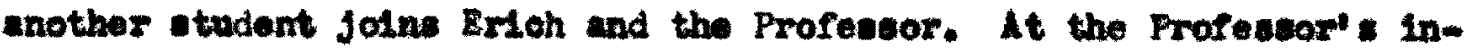

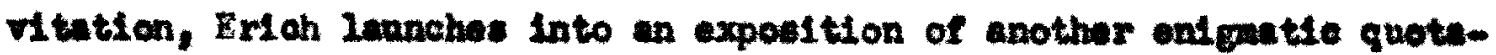
tion from Lather, "sin boldly, but bellere and rajoloe in Chrlet mare boldly atill." 9 he eonoludes hie explunation by aying,

- who can thic be anda to, exoopt the perean who malkes a remunctation of in wory div, from the betta of his heart? Tho enn har thos words without ondangering his falth but an tho heare tbelr consoletion as now onll to rollow Jenus Christ? Ion't thet

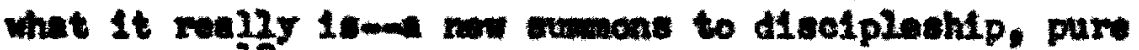
and of imple? 10

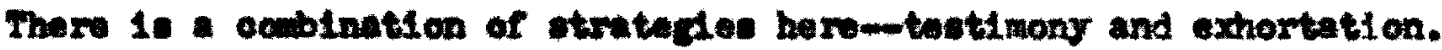

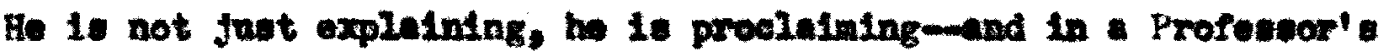

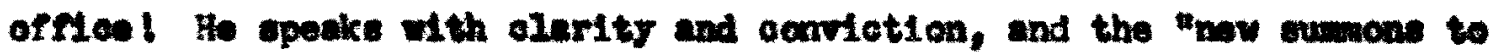
disolplechtp" is an advibration of the rigorous corrice that 2 les aboed of him.

Before the confermae is ended, the Profeesor adk Brioh if he ha:

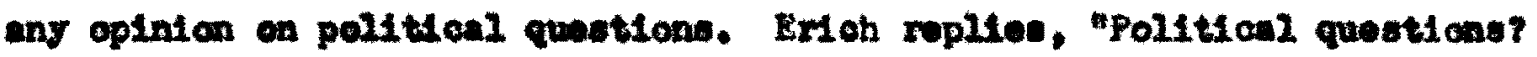
I dos't undervtend, alr. Whe nve politios to do with the life of

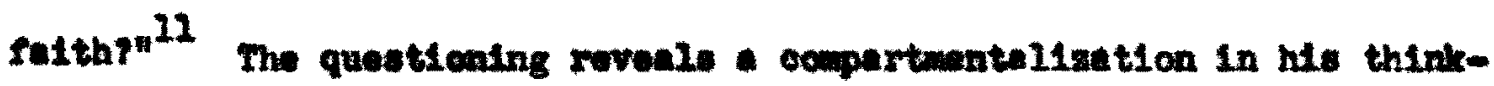

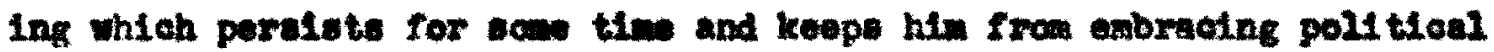

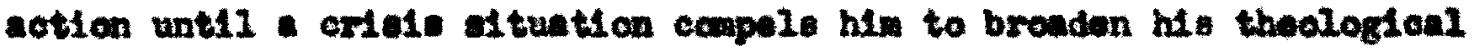

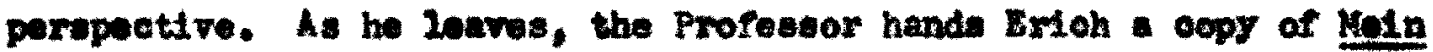
Inef.

Marrative epesches and a redto amouncor provide histarloal informetion on the paried of Hitler' tekeover and the Fredhorfer

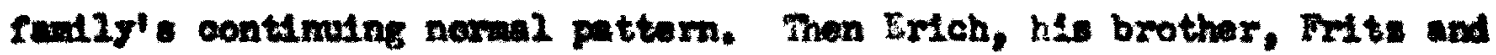


his good Irtend Emst are ahom in meadow in the Black Forest. They find a snake, and Erich prevente Ernst from killing it. He says, "I can't halp 1t, Frnat. Even if it's only a snake, It's alive. Don't you see what I mean?"12 He 18 ualng atrategy of reverence for Iffe that makes nore bellevable the intense strugglo he undergoes later before he can join the assasination plot.

An important redio announoement is hoard in the Frledhoffer home:

Ladies and gentleman, we bring you a special report from the eapital. Today, Nirch 23, 1933, 1 an historle day for the Geman Beloh. Just a fow hours ago, the Relchatag Irtunily eet aslde the Weimar Conatitution to place almost unilmited powers in the hande of our beloved leader, Adolph Hitler. But one thing should be made olear. Chancellor Hitler has taken this extruordinary power into his own hand only to regenerate our beloved howeland. As Hermann Soering and in apecial interview after the sesalon ended late todny, God has sent Adolph Hitler to aure Cernany. Wo aro all creatures of our leader. His falth makes us the most ponverul of men. If he removes his confldence, we are nothing, wo are plunged into darkmees and lost to the memory of man. Cerwany is lidalph Hitler!l And now ve return you to our maln atudios in Berlin. Hell Hitler 13

The strategy belng used by the amouncer is propagands. It servee to show the trend toward 1dolatry alresdy being oncouraged by the cerwan officials. The use of religtous terms, the Identiflcation of Hitler with the nation, and the blind truet asked for him all heve the effect of surrounding Hitler with an ara of divinity.

Tis Implication is not loat on the Friedhoffers. Erlch calls 1t "half-truth, half-11es-and all woven together in a pattern of uglinese and distortion that fllls we with naused." ${ }^{14}$ A they discase the meaning of these current events, Erich decides thet someone ohould apeak out, and that it must be he. When Fritg asks, Why does it have to be your decision?" Erich replies, "Who else do I have the right to decide 
for? $^{15}$ The strategy is pereonal responsibility, and Prtedhorfer

realizes that it is the basis for effective action.

The scene fades, and a radio executive addresser the audience,

using the strategy of ridicule in justifying the network's act of

cutting Friedhoffer off the air. He says,

For the first time in years we see sane kind of real security for curvelves and owr country-and then this pastor (he spits the word out es if it were en epithet) Eries to tell as wht we see as good fon't good at all, It's only ovil masquerading as good. 16

A clerlo speaks, giving the stand of the "established" chrrch.

Is 1 better to defy the govermment and ultinately deprive the people of the ocafort and solace of their churches? or is it better to keep the churches open oo that our people may have places to worship-and pray for the best? We belleve that by adjusting our thinking to the obvioue facts, we are simply boing realistic. 17

The two apeeches provide needed hletorloal background without adding scenes that would make the play cumbersone. They also show the wideepread acceptance of the savior Image H1tler was bullding up. The churoh was willing to compromise in order to save 1toelf. Th1 indieated the pervaniveness of the attitudes Frledhoffer felt compelled to attack.

A British Bishop tells the audience of Friedhoffer's move to Landon, and defends 1 t as way of trying to alort outsiders as to what was happening in Germany. The refers to Friedhoffer's return to Derman to teach in the clandestine seminaries of the Confessing Church. There followe an impressive serles of contrasts between what Erich 1s teaching in the wendnary, and what is being aatd to the youth of Germany by the Nas1s. The Navi strategy is Pag-Waving; Erich's is testimony to the Chrietian faith. Frich's teaching 1a Interruptad by 
the arrival of his father, who persuades hin to lenve for Merlon in rlow of Impending war which, they both know, Erleh would be unable to oupport or serve in. That he otill bellores his maln work is theologcal, not pollticel, is shown by the IIne, "I mat be where I can do $x$ work, Papa, If 1 cannot be here, then I mut go where it oan be dome. "18

A narrative opeech of the Mother's tells of the atart of the war. Erlch, In Nev York, agonizes orer his decision for the ruture. He is show at prayer:

Father, I no longer know why I an here, What an I to do? Do you wioh w to otay here in safety while my people in my homeland suffer? W11I I heve the right to go back to work wth the for nov 11 fe after 1 t 1 all over if I do not ahare the trialo of this time with them? $O h$, Ood, chow we the way! Am I to go--or in I to atay?l9

The etrategy of revealing shows how Erich' Impermost being is tormented by the atraggle that contimes to bulld up in him. His answer cones Wth the help of a pasaage from the book of Jeromiah. He returns to Germany.

His eivter, Era, her buband and Mrits aok hln to joln tho conoplracy in the plot to ascabsinte Hitlor. He Io greatly shocked. He anowers, "No! I could nover do thit. Bra, you know that. Iou knew I could never consent tommurder. ${ }^{20}$

In the next scen, Buloh 18 vialted by feinrich Mãuer, a representative of the gorerment. He warno frledhoffer against getting inrolved in any rosistance activities. Uoing the strateg of mirroring, he reflects the traditional Now of religion as ho saye,

I beg of you, don't be a fooll You hare no enll to sacrifice yourself. You are a man of God. Stey wth that. Hang onto It I1ke grin death. Frlodhoffor, for God's sake, stay with the next world and leave this one to those who realiy think it antere ${ }^{21}$ 
To which Ertich responds, Whd what if I think 1 t mutters $t^{n^{22}}$ Hore he alludes to the conviction which grew steadily otronger in him that the world is the arena of God's concern and actifity.

Erlch says, You have halped we to see things I have nerer boen able to see before," and Külier departs. There is then a scene in which Erich 18 deploted in a deep and exhausting battle botween his scoepted ralues and what seens to be a divine onll. He hears the sounde of hatred and ant1-8onttion, and he hoare the words of Jeous, "O $\mathrm{y}$ Futher, if it be poseible, let this oup pese from in I Neverthelese, not as I w111 but as thou w11t, 23 These words were apoken by jesus in the Carden of Gatheoman, and aro sesoolated with temptation and ouffer1ng. The atrategy is to 1dontify Erich with a struggle of a einilarly profound nature. It 18 plain that his decision will be based on his rasth.

We rery quidkly leam his deolelon, for Bra enters, and Extch telle her that he is ready to join their group. Ho tells her, "It waane I wish to Join jou, my oleter. And may God have meroy on our eouls." 24 There are echoes here of his discuseion with the Profeseor of the igin boldly" paseage from luther. Erloh axpects that God w12 have morey on their souls. The Mrat ast ende with the reoftation by Frits of the 8scond atanst of "Stations on the Roud to Froedon."

Once Ertoh comalts himelf to the conmpiraey, he is the noot sealous and Inderatigable of the all. Be undertakes a dangerous miation to Swodon as the group tries to get aseurance of capport fron cormeny" onemies in the event they oun uccessfully dopose the goterniont. As he and Joham discuss sow of their personal fealinge about what they are 
doing, Johann says, "The hand that 18 raised when the time comos nill not eran be ours, for that matter." Erich replies, "Ho, Jobann. . If the time does come when the hand is ralsed, whether or not it in ours, it w117 be ours. And the gutlt w111 be ours." Johann responds, "And foelIng this way, Erich, hou do you go ahead? How can you-c" and Ertoh answers, "I throw myself in the ams of God-mand pray to watch with Chrlst in Gethsemane. ${ }^{25}$ Once again, the strategies of teatimony and Identification are employed. Ertch has a strong sense of corporate gullt, as well as corporate mercy.

This mission fails, but Erich is determined to go on In spite of the general sense of despair. Eva agrees and declares thet the would have nothing to live for if theg ware to give up now. Erich replies,

Never say that. Bva, I forbld you! You always have womothing to live for. Lifo is to be lived for-cod is to be Iived for. Do you think we are here for no purpose? Porhape wo cannot soe it at the moment, but It is always therv. Even now, are living in that purpose, breathing that purpose. It 1s hard? Who told us it would almays be easy? We are lonely? Who told us we would never have to be Ionely? Wo are alive, wy alstormand God himeelf, alone end in egony, died upon a crgss to let us know the cares! How do we dare ask for more?26

The stretogy here is a combination of chiding and tostimony. Ertoh feels that his olster has expressed a foeling that 1o contrary to wat they are really doing. Their goel is not just to k1ll Hitler; their gonl is to live the Ilfe of obedience to God, regardless of the polleles of the state. Now, that mans trying to k1ll Hitler. Later, it will mean scmething different. But he feels he must chide his sister for confusing the weans with the end. It is also an exmaple of Erich's fatth-me falth that gustaing him oven in tho most discouraging clroumstances. 
The next scene tells of Erich's arrest and imprisoment by the Gestapo. Irnst reads stanza three of "Stations on the Road to Freedom." "Suffering," and relates how Erich was able to send letters out of prison to his fanily and friends. He reads from one of them as the 11 ghts como up on Erich, who acts out what is being read. Then Erich is taken for interrogation.

The interrogator, Dr. Keppler, tempts Triedhoffer wth the prospeot of belng returned to his fantly just by saying a fow words. Erloh replies,

No! I will not! I a Christian, Dr. Koppler. Do you know what that means? It means that wine is the cause of Chrlst. I cannot deny him. He is mother and my father $\rightarrow$ my brothers and my aloters. I have no cholce. Hitier is not my leader. I have no leader but Jesus Christ. 2 ?

The stratagy of testimony reveals Friedhoffer's dateraination to malntain his commitment in the face of grave pressure to conform. Aftor Keppler threatens to torture his fantly, Frledhoffer ahows that such tacties only reinfores his determination. He responds,

Oh, I see 1t now. I see it clearly. You have given a new pieture of real1ty, Dr. Keppler, and for that I muat thank you. Satan is truly at work in the world. And ho has men to help him; not only to holp him but happy to help him. And thus you are not men at all, but Flenda!

Oh, I admit, you suceoeded for a moment when you tempted me to distrust mु own motires. But now you have gone too far. Now you are out in the open whore the battlefteld is clearly marked and pletory is already won! Did you think I could not take the rlok? Woll, you were mistaken. I can take the rlsk-I do take it-and wy family takes it with me. Becouse unIike you and the others like you, wo know we do not take it alone! So do your woret, fiend. Use the old ways to torture us or find new ones if you can! Myself and all thoss dear to I place in the hands of God. And you-you I leave to His judgment! 28 
Frtedhoffer is using strategles of conterspt and challenging in these Iines. He shows his oontempt for Keppler and the reglme he represente by calling them "flenda," and by loaving them to the fudgment of God. The challenge is sumed up in "So do your worst, Plend." Freldhoffer is prepared for the battle that muet be waged Innedfately, but his language suggests that he hae another, more univeraal battle in atad: the struggle between good and er11. It 1a by being pleoed "in the handa of God" that the "viotory is alrady won." Thus the strategy of test1mony to fafth is also present.

Dr. Keppler revete wth fury to this challenge and orders Erich romoved. As he 18 lod amay, Erlch turns and says, "Telline, Dr. Keppler, when they told you there was no euch place as heaven, did they also tell you there was no hell?n" ${ }^{29}$ He appeare to be goading his interrogator in that line-at least it has the effect of making Keppler even angrier. It is the kind of question, however, that might well stick in the minds of nembers of the audience, and cause them to consider the nature of good and evil.

The scene that follows show Erloh's helpfulness to the guards and to other prisoners during an air raid. It also reveals Erich's own feare and angulsh. It is followed by a soene introduced by the mention of letter written on July 2lat, 1944, the day after the assassination attempt had failed. During the ocene, Frledhoffer learns from a guard of the fallure of the scheme into which he had put oo much effort and hope. He also learns thet sowo secret docunents hwe been uncovered which connect a number of people with the consplracy. His shock $1 \mathrm{~s}$ obvious, but he manages to romain non-comalttel in his convereation wth the guard. After the guarde departure, he takes the bread the guard 
has brought, breaks it and real1zes the simflarity betwoen what he is dolng and the sacramont of the Lord's Supper. 30 He praye quiletly, and then "opeaks" the letter he is iriting to Ernet.

I have discorered that it is only by living completaly in this world that one learns to believe. How can success make us arrogent or fallure lead us astray when ve partiolpate in the eufferings of ood by living in this world?

I am sure of Dod's hand and guldance. You must never doubt that I an thankful and glad to go the way whioh I an being lod. My past 11fe is abundantis full of God's nercy and, above all in, otande the forgiving love of the Cruclfled. . . Take care of yourself and don't lose hope-we shall all mest agein coon 131

This is a strategy of encouragement. Erlch's falth in apite of the tragic news may be a helpful example to his friend. It also showe h1: acceptance of the blow that "living completely in this rorld" has brought his. It is inportant to distinguish acoeptence froin realgnation. There is no hint of realgnition in this speech-monly a hopefulness thet springs from his courage and his falth.

In the final ecene, Erich is presching to a mall group of his fellow prisoners, He any,

And we must alwaye live close to the presence of God for that is nownes of 11ro, and then nothing 1s impoesible, for with God all thinga are poselbles no aurthly power can touch ws whout his wil. We can clain nothing for ourselves-and yet we may pray for everything. 32

Ho 18 giving encouragenent out of his own personal tostimony. In a eltuation that seems to offer nothing but despalr, he speake of hope. His faith in God is pat into terms that ehare his convictions with his hearers.

Together, Erich and the others recite pasage from the Old Testament that cancerns suffering. They are interrupted by two castapo 
agento who have come for Frich. In bldding farewell to a fellow prtsoner, Frich says, "This is the end, but for me-ult is the beginning of $11 \mathrm{fe} . n^{33}$ He recites the final stanza of "Stations on the Road to Freedom," and the Ifghts slowly go out.

We now ask whether or not the rhetoric of the playwright preserves the Integrity of the 1deas of the central character as evidenced by the rhetortc in the original works of Dletrich Bonhoeffer. To answer this question we w11 look at the 1deas which are central to srioh Prledhoffer in the play, and compare them wth the ides of D1etrich Bonhoeffer as wo found them in our enelyeis of him and his rhetorlo. First, Erich had a profound falth in God. We see this in the childhood scene, in his testimony befor the Professor and among his students in the aeninary of the Confeasing Church, in his testinony and challenge to Dr. Keopler and in Mig letter from prison. This is also one of the key Idess found in Bonhoeffer. The strategles of expressing it are sinilar, as well.

Second, Frloh bellered that he must obey God at all costs. We find this most explicitly in his chiding of Fva and his testimony at that potnt; but 1t 1o implied In many places, eapecially in the soones where he is depleted as wrestilng wth a decision about future undertakings. This, too, wo found to be true of Bonhoeffer. It was found thare more often in the analyos of Sonhoeffer as agent, but was explieftIy stated in the rhetorle as well.

Third, Ertch recogniagd the ov1l and 1dolatry of the Naz1 regime. This 1s, of course, behind all of his actions in opposition to 1t, elno he was convinced he was obeying ood. It 18 expreased in his reaction to 
the propaganda epeeoh on the radfo, and in the responses to his own opeech frow the notwork expoutive and the Germen eleric. Once again wind Bonhoeffor expresoing the ane 1dos. With hin as wth Friedhoffer, it io a besio undorlying factor. It is also otated in the rhatordo.

Fourth, Erlch belleved that the churoh had beon unfalthful. Ints 1. show by his disassociation with the establishod church, and by his reaction to Herr Muller' compromleing attitude. It does not, however, conatitute in the play as importint an Ldes as It did in the 11 fe of Bonhoeffer himself. There it was a anjor thene in the easay on Baptian. Fifth, EMch had a savere conflict of Ideas between the theologleal and the politieal aphores; between his traditional bellefa and whet he

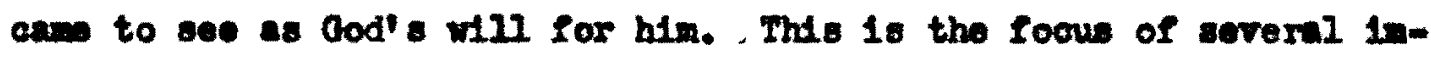
portant scenes. It is adumbrated in the deplotion of his reverence for 118 In the madow soene. It 18 the central theme of the soane in New Iork and the scene in the garden of hil howe after the rist of Miller. We found no hint of this in the rhetorlo of Bonhoeffor whioh wh selected for analyais. In the discuselon of agent, Bethge refors oree to the diffievity Benhoeffor had in adjuoting to the new conrictions he held and wa following, but the dociston 18 seen as a moro gradual process. When we look at the nature of the deelelons and orents involved, we cannot help bat believe that there un a good deal of otruggle for Bonhoeffer, but that he almply did not talk about it much. It would be very difficult to portray a long, gradul procese on stage and retaln dramutic interest. 81xth, Erleh had a groat hope for the future. This wa based on his falth in Ood, as we in his tootinony to Bra in the chiding sowe, 
and in the letter of July 2lst. It 18 implicit in many opoto where he is seen working and planning purposefully, rather than restgnedly.

Thus, on the basis of four direct paraliels in 1deas and two strong associations with no contradictory findings, we would answer that the playwright did, in fact, preserve the Integrity of the ideas of Dietrich Fonhoeffer in the character of irich Friedhoffer.

In the play, we see Irich as, above all, man of falth. His oomitment to whole-hearted obedience to God comes across over and over in both speech and action. It is central to him, and he urgos it for others. We find him to be a man of action, not content with worde or theorles, even though they be theologically correct. He must follow what he belleves with what he doea. This is not achieved without a etruggle, however. Te faces agonizing decisions over what action he io called to take. Once the decision is made, he gives hinself to it with complete dedication.

In what he says and the aotivities he undertakes, we discover thet he 18 committed to the ldea that God is very much in the vorld, and that that is where man must serve him. He finds much to enjoy in the world, In eplts of 1ts ev1ls. Fe enjoys his family, his friends, his work, the out-of-doors, his musto. There is a strong Identification of Erich and what he says and what he doos. Act, agent and purpose are fused by the depth of Irich's deep convictions.

These are the same qualities we found in Dletrich Eonhoeffer. As we studied him as agent, we found his cruclal dectsions to be made more aradually than they are deploted by the playwright, but the easential nature of them is not istorted. The most recurrent feature of his 
rhetoric we found to be testinony-me stating of the theological bases of his convictions and acts. This is also true of Ertch. Bonhooffer came Increasingly to espouse a "religlonless" Christiantty, a trend reflected in Frich:s prison scenes, though not as markedly as found in the passage about baptzam.

The overwhelming sense of absolute deedience to God is clear in both the historlcal man and the dramatic character. The act of execution 1s the slgn of the refusal of both to give up that part of themselves. They remained falthful to what they conoeived of as Ood's will for them.

These then are the elements by which the playwright wa successfal In preserving the Integrity of Bonhosfer's ideas in the rhetoric of the play. 
1. Eberhard Bethge, Dletrloh Bonhoeffer, trans. Erto Mosbacher, et al. (Nev York: Rirpor \& Row, 1970), p. 9.

2. El1sabeth Borryh111, The Gup of Trembing (unpublished manuacript, 1953).

3. Iold., p. 1.

4. Iotd.

5. Hetrich Bonhoeffer, Letters and Papers Irom Prison, ed. Wberhard Bethge, trana. Reginald H. Fulier TNev York: The Macmillan Co., 1953), pp. 229-9.

6. Fizabeth Berryht11, op. clt., p. 2 .

7. Mbid.

8. Mold., p. 4 .

9. Tb12., p. 5 .

10. Iold., p. 6.

11. noid., p. 7 .

12. Tb1d., p. 10.

13. Io1d., p. 11.

14. Ibid.

15. Iold., p. 12.

16. Bb1d., p. 13.

17. Io1d.

18. To1d., p. 16.

19. To1d.

20. Ibld., D. 20 .

21. Ib1d., p. 24.

22. Tb1d.

23. Ib1d., p. 26. 
24. Ibid.

25. Ibid., p. 29.

26. In1d., p. 31

27. To1d., p. 35 .

28. I01d., D. 36.

29. Tbid.

30. To1d., p. 42.

31. Tb1d.

32. Ib1d., 0. 44 .

33. Ibld., p. 45. 
GAPTER VII

\section{muctretox}

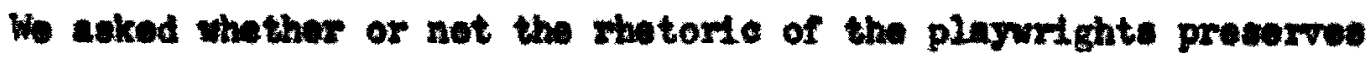
the Irtegrity of the 1deas of the oentral charactere al evidenoed by the rhetorlc found in their orffinal vorka. In attompting to anower that quostion, we have wade a metomeal analycis of two wen, S1r Thowe Wow and Dietrich Benhoeffor, ueing the dramatietic pentend and the nuing of stratogles. We have then made a similer amalysis of two plarr, A Man for AII Sagone, in which Kore is the contral chnraeter! and The Cap of Inebling. In thion the oontral oharacter is nodelled artar donhoeffer.

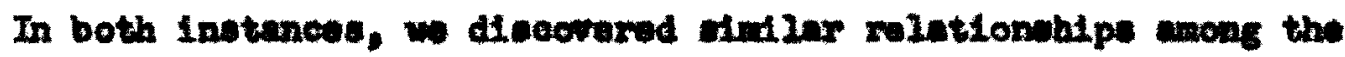
lewente of the pontad. The pluymghte wero ble to ralate the charaoter, or agenta, to tholr attuations in oroh a way that the mesage of the entire orent was portrayed falthfully. Whale found many Identioal and otmilas otrategles being wood by the hiotortoal figaro and the dramatic charmeter. Mis oan be partially attributed to the playnighta' use of the exact words of the parson. But monty It cases from an ability in charactarlation that gives an alr of authenticity to the playurighte' creationa. Thus we ind the otrategr of testinony baing need by both men, and by both characters. It is an Important aspect of perromallty and purpose In ench case.

In addition to these sindiuritien we found thet the key conopt 
In the lives of these two men, namely conscience, stands out clearly in the two plays. With Sir Thomas More, it is the word "conecience," and the need to preserve that portion of his "self" that constitutes his essential honesty. Wh th Bonhoeffer, it is called obedience to God. In both cases, it is the area of selfhood in wich the man perceives his integrity to reside. It is the underlying factor that unites the man and his situation. In both cases, the playwright kept this identifying characteristic intact.

By tracing major ideas we found in both cases that those of the central oharacter in the play were essentially the same as those of the historical men studied. This was somewhat more complex in the case of Bonhoeffer than it was with More. This is because the lattar left us one single example of rhetorlc that dealt wholly with the great issue that determined so much of his later years, namely, the matter of the King's divorce. It was the one issue on which Wore conopleuously rebelled against the 71 g. Bonhoeffer, on the other hand, opposed everything the Nazis stood for, but his rhetoric was much more general and was focussed, not on his opposition to the Naz1s, but on his obedience to God and the meaning of that in many areas of 11fe. Nevertheless, with both men the playwrights succeded in selecting the strategies and the ideas that faithfully represented what the historleal flgures had belleved.

We conclude, therefore, that the playwrights did preserve the integrity of the ideas of the historioal figures trough the rhetoric of their plays.

It may be instructive to ask how the playwrights achieved this 
result. Some of the ways, such as use of the sane or almilar strategies, use of the person's own words, preserving the relationshtps anong the elenents of the pentad, have already been mentioned. Uaing the same words w11l not automatically insure preserving the integrity of 1dess. The playwright has to find some way of making them belferable. All of the elements of characterization are involved. The words mant be introduced at the right time, so that the audience is propared to accept them. Whether he uses the dramstistic pented or some other derlce, these are the elements of the situation that muat be kept in balance in order to make the words believable.

Another means of preserving the Integrity of the man's Ideas is to hlghlight certain events and detalls in the story and eliminate or play dom others. Th1s allow the focue of the drana to remain on those traits the playwight wishes to emphasixe. Fortunately, both of the playwrights in this study chose to emphasize the right tralts to portray accurately the esential nature of their subjects. Both of them oliminated certain characters in their stories in order to conoentrate more on those who contributed more to the heroes' essentlal image. For exomple, of More's four ohtldron and numerous wards, only one appeara In the play; Bonhoeffer had seven brothers and alsters, but Erich has only two.

Both playwrights had one excellent devios bullt into thelr etorles, both for schtering a sense oc drama and for making the ideas of their central charactere bellevable-the executions. The decialon to forfelt his Ilfe rather than give up h1s comrletions does a great deal to nake an appear belierable, and both playmrights make good use of these 
dranatic real1ties from tholr charactere' hiatories, The actual exocutions are handled with reatratnt, but are mado reallatic enough to comvy the etrongth and Ninality of the aot.

In comparing the to charecters, we find that they had ming ofrcumatances in camon, in addstion to the matter of conceience alreadr wntloned. They were both Interested in theology, though More ma a Inywan and Bonhoeffer an ordained clergyinn. Both had a groat intereot in the rolationship between the church and the atate. Both of them IIved in totalitarian states, and it wa this fact that made their otands on comviotion more notlceable than they wight otherwise have been, and that Ied erentrally to their deathe. In whet wo rend of Hore's discouree, it would appear that he was ready to go along with the state, or nore accurately, King Renxy, In alnost ererything except the watter of the anriage and the lawe thet pertainad to It $_{3}$ whoreas Bonhoeffer apperantly saw no good in the Nas1 regle and was totally opposed to it. Ihough nelthor wade hia stend elone, Boakoeffer probably had more company in his point of view than Moxe 11d. For both of them, doath was inoritablo once they determined to persevere in the otand thoy had taken.

There are several important and olgnifloant ldeas which cone from these two men ria the playe. One is the Importance of keoping the "ealf" Intect. The contragt between the wen who refued to violate the Innormoat fortress of their belng and those aaved thetr lives by comprandee and adaptation 1s stark. It showe a nobllity that doos not end at death, but on be traneaitted through history. Those two who found life so enfoyable and rewarding were not afrald of death, and considered it to be a leaser evil than the betrayal of their courlotions. We are also 
reminded that there are certain functions of the state that are legltinsto, and sane which are not. When the state attempte to intrude on the domain that should be reserved to the Indifiduals in it, scmething essential is lost, and strong men w1I fight and, if necesary, die to keep it fran being lost forever. In making their 11ght, both won found tromendous strength in their falth. More had an additional weapon In the law, and he used it mightily.

What are the Inplioations of the conolusion we have reached? For those who are interested in rhetoric, it is important to realise that rhetorlc can be preserved then transferred from its orf ginal form to drema. If a Vion is important enough to try to perounde people to adopt 1t, then $1 t$ ohould be Iaportant enough to use the beat rhetorical means arailable. Thls annlrula denonstrates that dram can be ued as one of those mears, and should be constdered as a possibility wher: varlous moans are belng considerw.

Of course, drum has been ueed as the rohicle of rhetorie in many Instances. These two are just two examplea of many ine plays that have had peravasive elements built into them. Howard Taubman says In speaking of the dobate and controvervy aroned by the play, me Deputy, "It 1s a reminder of the enormous poner of the theater as a forun for burning, controversial 1deas. Thet power has been inpliclt in the atage for millennium. ${ }^{1}$ He gives examples from wany different hlatorical eras. He conoludeas

There is scasthing eles about the thester. It is a vivid, communal expertence. In the rery procese of beling actod out, a theme beccies tanglble and risible. If 1 t comreys chock and exeltemont, the cotional radiations between etage and audience deopen the group reaction and Inteneify the Indiridual reaponse. 
No one would wish the thenter to be only a sounding board for broadeldes and polomics. It can be 80 many other thinge-eseape, laughter, myotery and, nost important of all, a high onnobiling art that reveals us to ourselves. But it is remarkably hospltable to the expreseton of overpowerting conviotione and moral Indignation. What a pity that it is not asked more often to be an exhliarating clearing house for daring, searching nev Ideas, Fight or urong.?

It might be asked more often if nore people who have shetorical

Interesto realized that drama can falthfully preserve the integrity of the 1deas of the people who become its characters. The reevits of this study indioate that it oan. 
NoTes

1. Hownend Tabanen In Dolores Barreanno Sohnidt and Baxl Robert

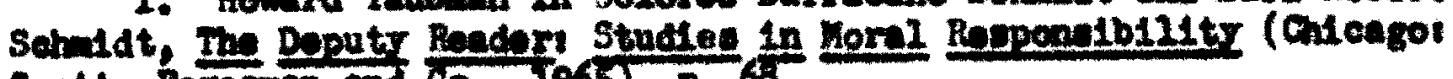
Soott, Foroenin and 66., (965), D. 68.

2. Hold., p. 69 . 


\section{A SILCrED BIALIOORAPI}

\section{Boors}

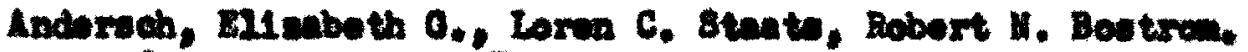

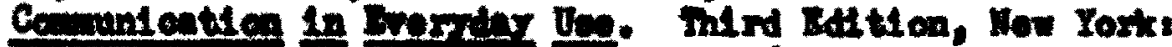

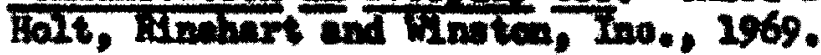

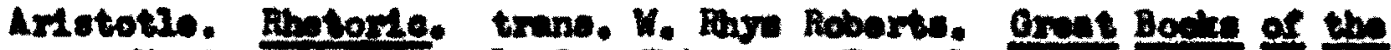

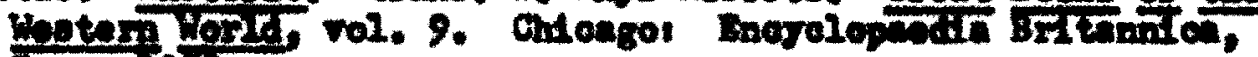
Ine. 195.

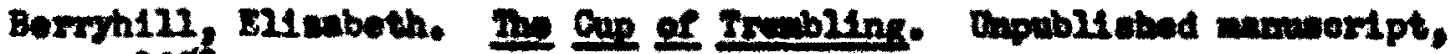
2950.

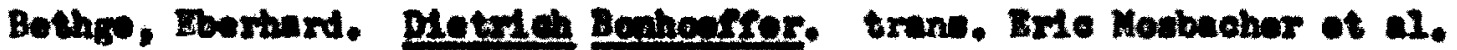

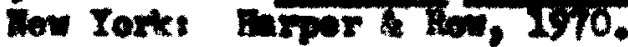

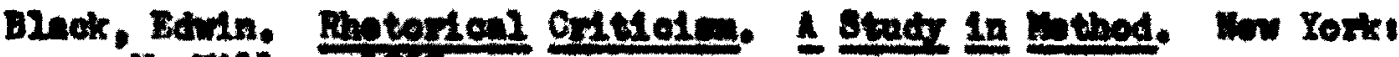
Merillen, Isos.

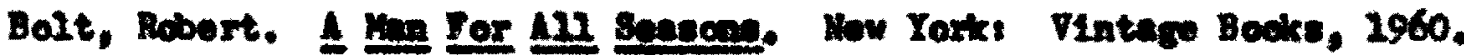

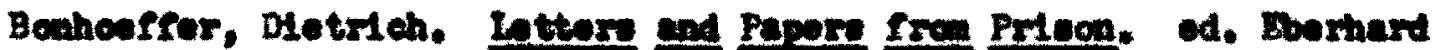

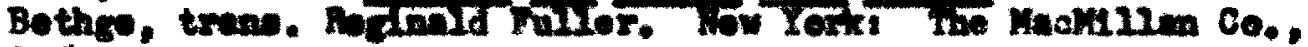
1953.

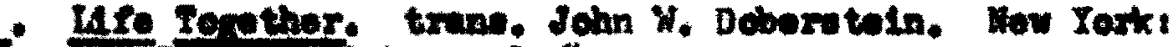

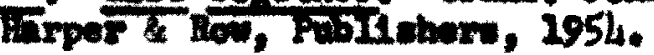

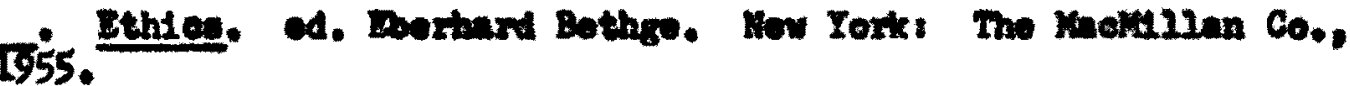

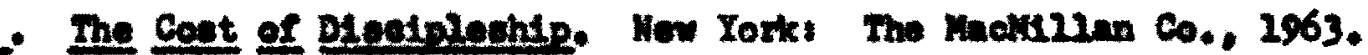

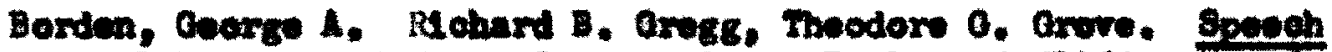

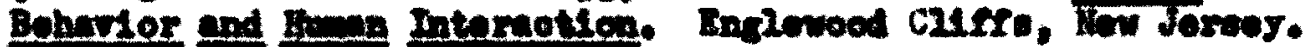
Pronatosin, ino., 1\%

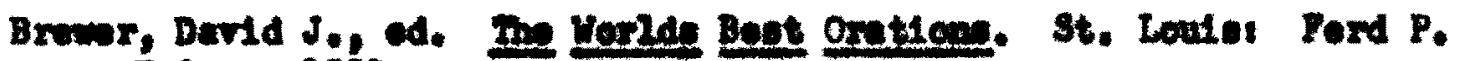
Kaleer, 1900.

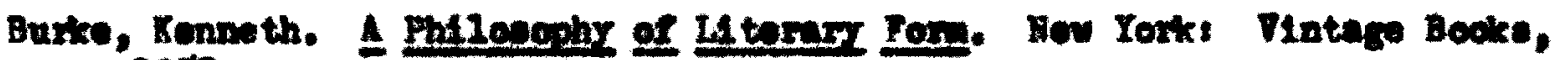
1957. 


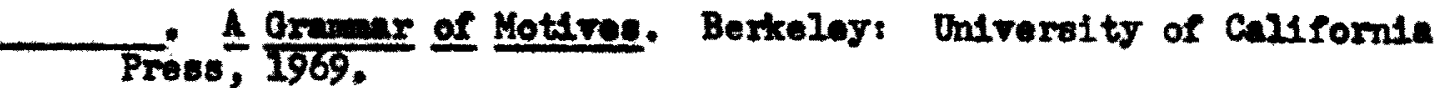

- A Phetorle of Hotires. Berkelogi Oniveraity of Callfornta Proes, 1969. -

Chabere, R. W. Thenee Yore. Inn Axbor Paperbackes The Oniverselty of Michtgan Prises, 1958.

Cole, Toby and Holen Crith Chinoy, eds. Directore on Directing. New York: The Bobbe-Merrill Co., Ine., 1953 .

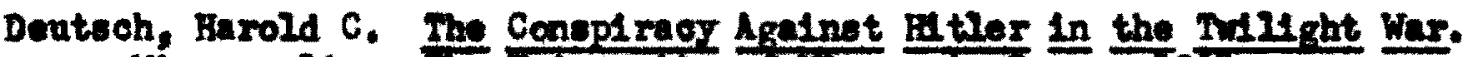
Minneapol1s: The triverelty of Timmotote Prese, 1968.

Qasaner, John. Direotions in Modern Theatre and Drouas. New Iorks Holt, Rhinobart and Winoton, Ino., 1967.

Aress, W. W. ed. The Book of S1r Thosas More. Oxford Dntrersity Presst Kalione sootety Roprints Igl.

Hoobmuth, Marie. A Hiotory and Criticien of Amortoan Publio Addreas. V01. III New Yorti Loagenan, Green and Co., 1955.

Hogrefe, Pearl. The 81x Thoas Kore CArcle. Urbanas The Univerelty of IIIInois Prose, 1959.

Holland, V1rginta. Counterpoint: Konneth Barte and Arlototle'e Moories

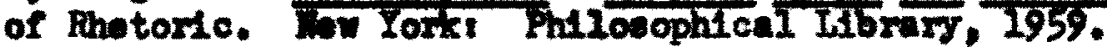

Korr, Waltor. The Theatre in Spdte of Itwelf. Now Yorkt BImon and Sehustar, 1963.

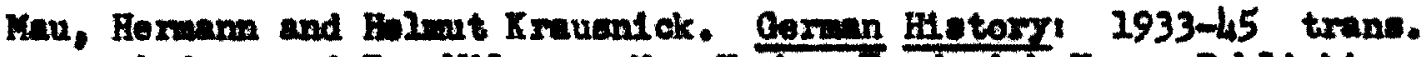
Androw and Eve Wilsen New Yoxki Tradorlok Ongar Publiabing Co., 1963.

MeBurnoy, Jawee H. and Ermest J. Wrage. The Aft of Good Speech. How Yorkt Prentlee-Hall, Inc., 1953.

More, Str Thouss. Vtople and Dielogee of Comfort. Londons J. M. Dent sons, Ltd. I9lo.

N1ohols, Marie Hockmath. Metorio and Criticien. Baton Rouges Loul ofian Stato Ontrerolty Pross, 1963.

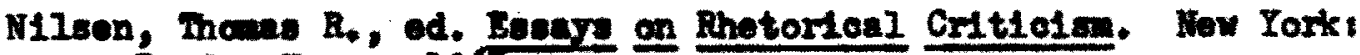
Panden House, 1966.

Remak, Jouchin. The Nas1 Yeare. A Doounontary Ristorr. Englowood Cliffs, H. J. Pronticomin, Inc., 1969. 
Reynolds, E. E. The Irial of S1r Thoens More. Now Iorks P.J. Kennedy \& Sone, 1964 .

- The Fleld 18 Kon. Mtlwaukles Bruce Pabliahing Co., 1968.

Roper, Willian. The Life of S1r Theans Nore. Richnrd S. Sylveeter and

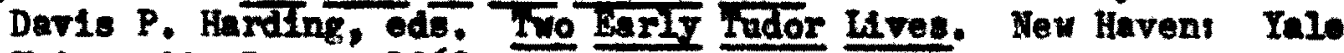
Untreratty Preas, 1962.

Sarott, Alad Johnson, Law Sarett and WIIIan Trufant Foster. Besic Princ1ples of speech. Booton: Houghton Minin Co., 1966.

Schnidt, Dolores Barracano and Eerl Robert Bchidt. The Deputy Reader' Studles in Moral Reeponsib111ty. Chlcago: Soott, Forvenan and Co., 1965.

Shirer, William I. The Fice and Fall of the Therd Belch. Now Iorkt Simon and Sohweter, 1960.

Soreno, Kenneth K. and C. Derld Kortensen. Foundations of Co anteation Theory. How Iork: Harper and Row, 1970.

Speer, Albert. Instel the Therd Re1ch, trang. Mehard and Clara Winaton. Few York the MadIIIan Co., 1970.

Sullivan, Frank and Majle Badberg. Moreana. Los Angeles: Loyola Inivaraity, 1964.

Thenssen, Lester. A. Cralg Balrd, Waldo W. Braden. Speeoh Crittolea. Thind Edition. Ien York: The Ronkid Press Co., 1970.

Zeller, Eberhard. The Plane of Proedca. London: Oowald Wolff, 1967.

\section{ARTICLES}

Brockrlede, Wayne E. "Dimenelons of the Concept of Rhetorlc." Quarterly Jounnl of Specech. Vol. ITV (1958), pp. 1-9.

De11, George W. MPhlloeophle Judgmente in Centemporary Fhetoricel Crlt1c1an." Western Speech. Vol. 30 (1966), pp. 82-88.

Driver, Tom F, "Seeing Man as Man." Chrlatian Contury. 79 (2962), p p. 576-577.

Flaher, Walter $R$, "A Kotive Fiow of Coumication," Qunrter2y Journi of Spoech. Vol. IVI (1970), PP. 131-139.

Holland, Virginta. "Rhetorical Crltiolowt A Burkean Method." Guarterly Joumal of Epeeoh. Vol. XxxX (1953), pp. 444-450. 
Thonssen, Lester. Mandom Thoughts on the Crytician of Orstors and Oratory" Weatern Speech. Vol. 32 (1969), pp. 185-190. 